\title{
Multichromic Triphenylamine-based dyes: Designing better interfaces for DSSC applications
}

\author{
By Omar Khalif Abdi
}

BSc. Ryerson University, 2013

\author{
A thesis presented to Ryerson University \\ in partial fulfillment of the requirements for the degree \\ of Master of Science \\ in the Program of Molecular Science, \\ Toronto, Ontario, Canada, 2015
}

Omar Khalif Abdi @2015 


\section{Declaration}

I hereby declare that I am the sole author of this thesis. This is a true copy of the thesis, including any required final revisions, as accepted by my examiners. I authorize Ryerson University to lend this thesis to other institutions or individuals for the purpose of scholarly research. I further authorize Ryerson University to reproduce this thesis by photocopying or by other means, in total or in part, at the request of other institutions or individuals for the purpose of scholarly research. I understand that my thesis may be made electronically available to the public. 
Multichromic Triphenylamine-based dyes: Designing better interfaces for DSSC applications MSc 2015,

\title{
Omar Khalif Abdi,
}

Molecular Science

Ryerson University

\begin{abstract}
A family of multichromic dyes with excellent light-harvesting abilities have been designed. They utilize redox robust triphenylamines tuned with thienyl-moeities. To confirm their performance as sensitizers for dye-sensitized solar cells, devices are en-route for fabrication and optimization with varying electrolytes. They serve as excellent candidates towards integration with a hole-transport material: forthcoming goals will involve alteration of the dyes to allow in-situ photo-electrical polymerization with poly-3,4-ethylenedioxythiophene. Solid state analogues of the devices present the ability to be manufactured through a directwrite process.
\end{abstract}




\section{Table of Contents}

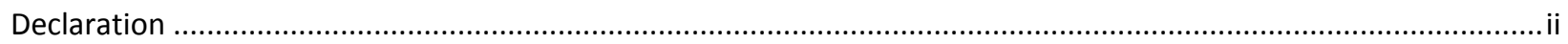

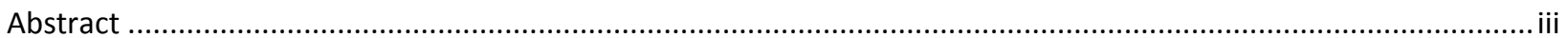

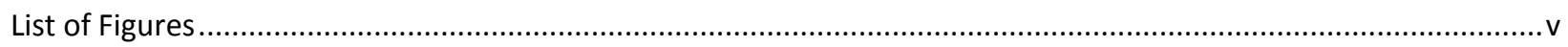

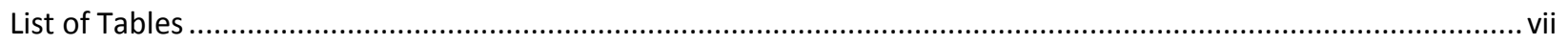

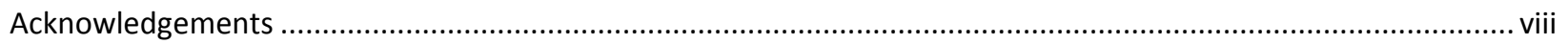

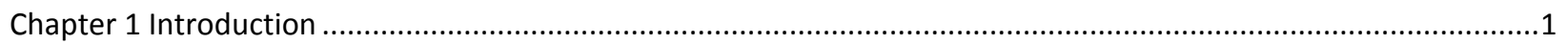

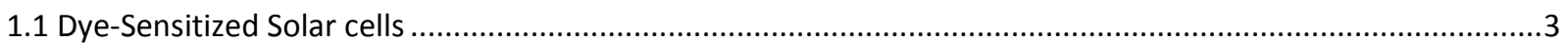

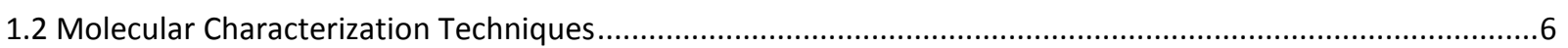

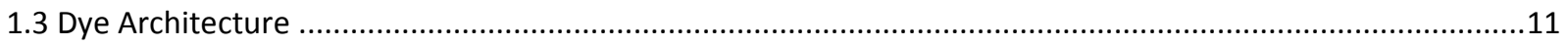

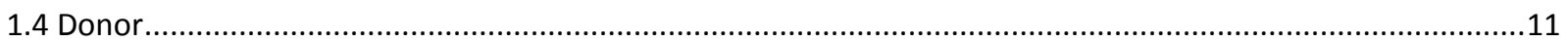

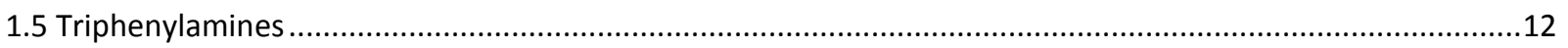

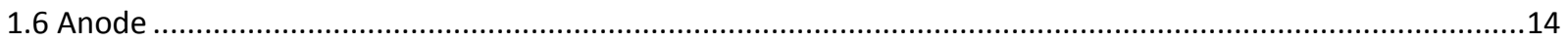

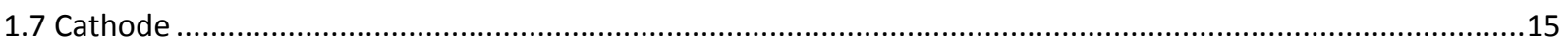

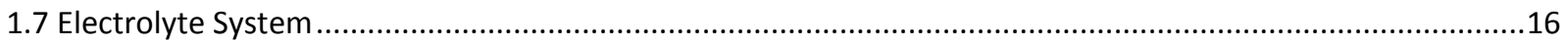

1.8 Objectives: Towards durable devices and panchromatic absorption. ..................................................18

Chapter 2: The Effect of Donor-modification in Organic Light-harvesting Motifs: Triphenylamine Donors Appended

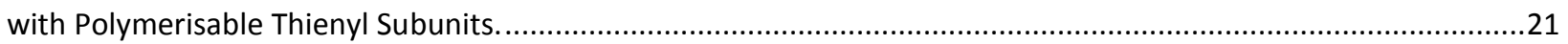

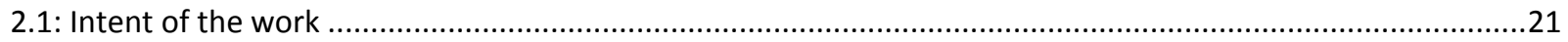

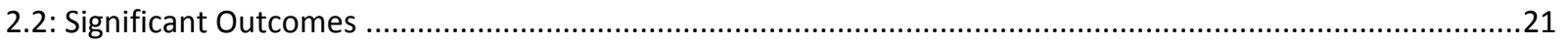

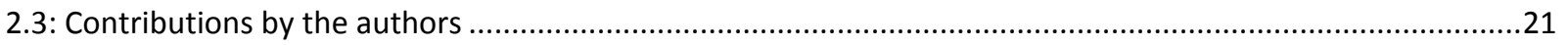

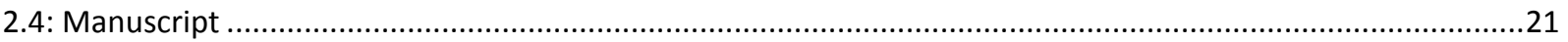

Chapter 3: Synthesis and study of bichromic triphenylamine-based dyes furnished with bipodal features for light-

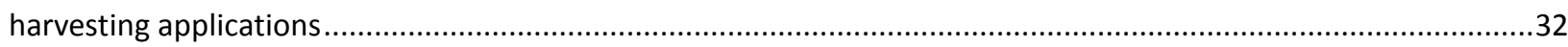

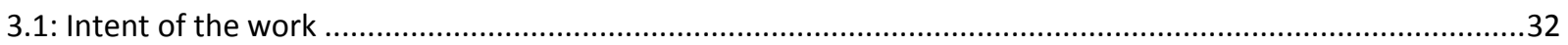

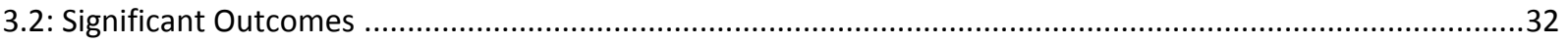

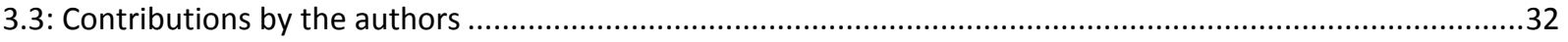

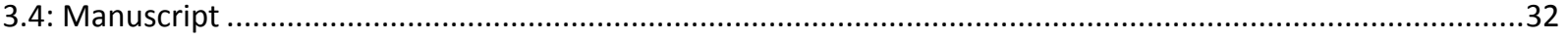

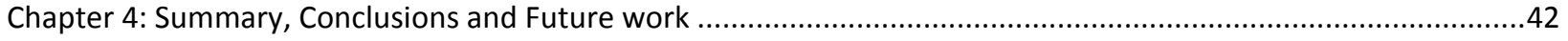

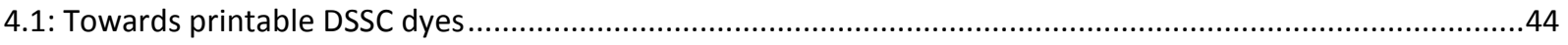

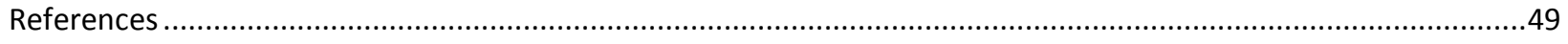

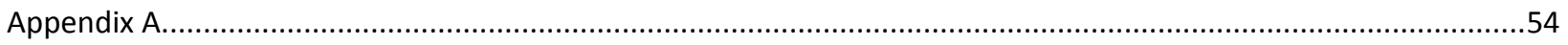

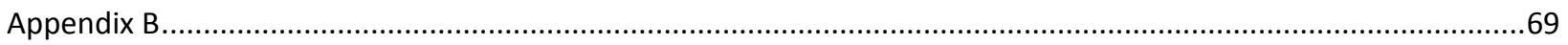




\section{List of Figures}

Figure 1 Total energy reserves of fossil fuels and uranium compared to total annual solar irradiance. ..... 1 Figure 2 Efficiencies of current and emerging photovoltaic technologies. ............................................... 3 Figure 3 a)DSSC working principle. b) Device anatomy c) Formula for the efficiency of a cell: is the power conversion efficiency. $J_{s c}$ is the short-circuit current; proportional to the number of absorbed photons. $V_{o c}$ is the open-circuit potential which is equivalent to the difference in the energy between the electrolyte and the fermi energy level of the titania. The fill factor, $F F$, is a measure of the maximum potential of the cell. $P_{\text {in }}$ is the incident power of light irradiated on the device. ..................................... 4

Figure 4 kinetically and thermodynamically favourable pathways for electron flow. .............................. 5

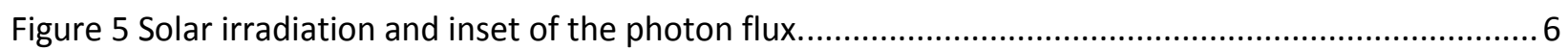

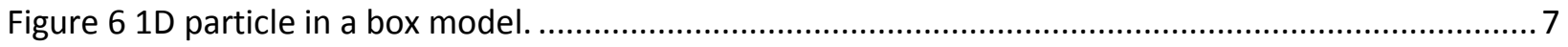

Figure 7 factors affecting the extinction coefficient show donor acceptor motif. ................................... 8

Figure 8 a) Mechanism of oxidation and Reduction processes at the frontier molecular orbitals. b) Illustration of redox processes occurring at the working electrode...................................................... Figure 9 a) Cyclic voltammetry potential wave form. b) Example CV of a dye designed in the Koivisto

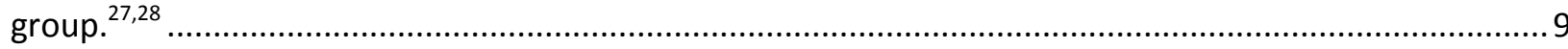

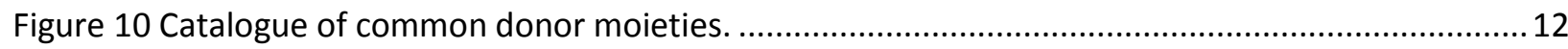

Figure 11 Image of TPA (white), formyITPA (orange) and diformyltpa(yellow). .....................................13

Figure 12 Electrochemically characterized TPA derivatives synthesized in our lab. Oxidation potentials

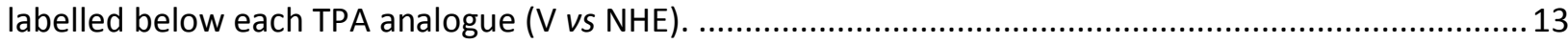

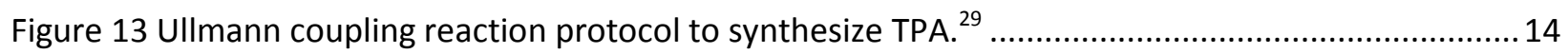

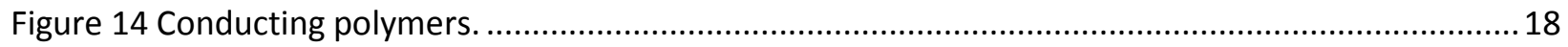

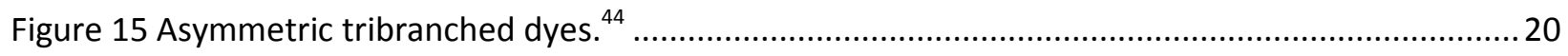

Figure 16 A Family of TPA dyes where the donor is substituted with various thienyl-subunits. ...............23

Figure 17 UV-vis spectra in DCM for the di-substituted TPA dyes...................................................2

Figure 18 Frontier molecular orbitals as predicted by DFT (B3LYP/6-31G) for di-substituted dyes 4b, 6b,

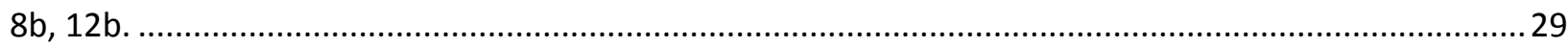

Figure 19 Photocurrent action spectrum obtained for di-substituted dyes attached to $\mathrm{TiO}_{2}$ films using the

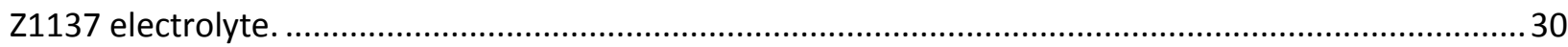

Figure 20 Bichromic Dyes: OA1, OA2 and OA3. A synthetic scheme is presented in the supporting information.

Figure 21 Dye OA4 and previously reported benchmark dye L1. Synthetic scheme for OA4 is presented in

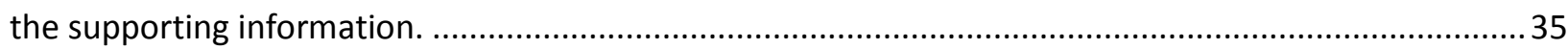

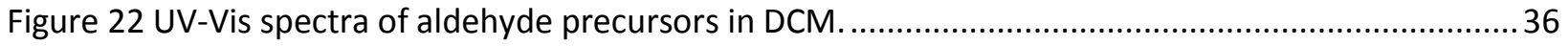

Figure 23 UV-Vis Spectrum of dyes OA1, OA2, OA3, OA4 and benchmark L1 in DCM...........................40

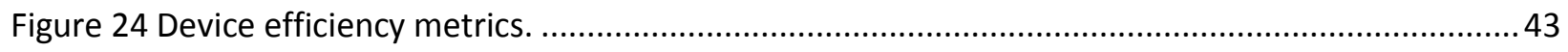

Figure 25 Candidate dyes for direct integration into a Hole-transport material..................................... 43 
Figure 26 Surfactants are often deprotonated to promote stronger binding onto a colloidal particle (right-most surfactant). For surfactants that need to be removed easily, they can be left in their acidic form and bond through a hydrogen bonding motif (left surfactant).

Figure 27 Regular paper has unevenly spaced cellulose fibres with microgaps that reflect light(left), oxidation allows the cellulose fibres to contract and close the gaps (right). ${ }^{74}$ 


\section{List of Tables}

Table 1 Electrochemical and UV-vis absorption data for dyes. ${ }^{a}$ Data collected using 0.1M NBu $\mathrm{PF}_{6} \mathrm{DCM}$ solutions at $100 \mathrm{mV} / \mathrm{s}$ and referenced to a $[\mathrm{Fc}] /[\mathrm{Fc}]^{+}$internal standard followed by conversion to NHE; $[\mathrm{Fc}] /\left[\mathrm{Fc}^{+}\right]=+765 \mathrm{mV}$ vs NHE in DCM. ${ }^{a}$ Data collected in DCM solutions

Table 2 Solar Cell Performance Parameters Obtained Under Simulated AM 1.5 Illumination for Select Dyes. ${ }^{a}$ Device fabrication and data collection procedures can be found in the Supporting Information.. 28 Table 3 Physicochemical characterization of aldehyde precursors. ${ }^{a}$ Data collected using $0.1 \mathrm{M} \mathrm{NBu}_{4} \mathrm{PF}_{6}$ $\mathrm{DCM}$ solutions at $100 \mathrm{mVs}^{-1}$ and referenced to a $[\mathrm{Fc}] /[\mathrm{Fc}]+$ internal standard followed by conversion to $\mathrm{NHE} ;[\mathrm{Fc}] /[\mathrm{Fc}+]=+765 \mathrm{mV}$ vs. $\mathrm{NHE}$ in $\mathrm{DCM} ;{ }^{\mathrm{b}} \mathrm{E}_{0-0}$ calculated from $10 \%$ of the absorption maxima. Further details for Table 2 derivatives can be found in the supporting information

Table 4 . Physicochemical characterization of $\mathrm{L} 1, \mathrm{OA} 1, \mathrm{OA} 2, \mathrm{OA} 3$ and OA4. ${ }^{a}$ Data collected using $0.1 \mathrm{M}$ $\mathrm{NBu}_{4} \mathrm{PF}_{6} \mathrm{DCM}$ solutions at $100 \mathrm{mVs}^{-1}$ and referenced to a $[\mathrm{Fc}] /[\mathrm{Fc}]+$ internal standard followed by conversion to $\mathrm{NHE} ;[\mathrm{Fc}] /[\mathrm{Fc}+]=+765 \mathrm{mV}$ vs. $\mathrm{NHE}$ in $\mathrm{DCM} ;{ }^{\mathrm{b}} \mathrm{E}_{0-0}$ calculated from $10 \%$ of the absorption maxima...... 38 


\section{Acknowledgements}

There are a number of individuals that I am highly grateful towards who have supported me in this thesis. The premier foremost one is Dr. Bryan D. Koivisto who is my principle investigator, and most importantly, my mentor. Through his rigorous training I have learned and grown significantly in the field of chemistry and materials science. Dr. Bryan D. Koivisto has been a source of significant support in my personal growth as well and I owe my successes in building relationships of all kinds to him. Special thanks to Dr. Catherine Bonnier as well, who was also initially instrumental in my training as a chemist. I owe thanks to my current and past committee members: Dr. Foucher, Dr. Wylie and Dr. McWilliams who have been there for advice and support on my project.

In no particular order, I owe thanks to my lab mates as well for their assistance and moral support: Muhammad Yousaf, Hardeep Devgan, Burhan Hussein, Jennifer Hyunh, Sara Abuadas and Benjamin Fischer. I am also grateful for the family and friends that I have, who alongside of Dr. Bryan D. Koivisto, have been there for me during the ups and downs of my research and personal life. 


\section{Chapter 1 Introduction}

As the burden of global energy demand rises, the search for environmentally friendly and economical sources of energy has intensified. ${ }^{1,2}$ Global energy demand is predicted to increase to 30 TW by $2050 .^{3}$ Petroleum is a major source of energy consumption. A popularized and legitimate concern with the use of fossil fuels is carbon dioxide emissions which are linked as a direct cause of global warming. ${ }^{4}$ Petroleum is also a source of raw materials in the production of plastics so by pursuing alternative energy sources their use can be prioritized as raw feed stock for the manufacturing industry. Energy technology that utilizes carbon-free sources have matured but are not without their problems or limitations: Nuclear Fission, solar, wind, geothermal and ocean energy. ${ }^{5,6}$ Among these options, solar energy is the most abundant (Figure 1 ) and the least detrimental to the environment. ${ }^{7}$

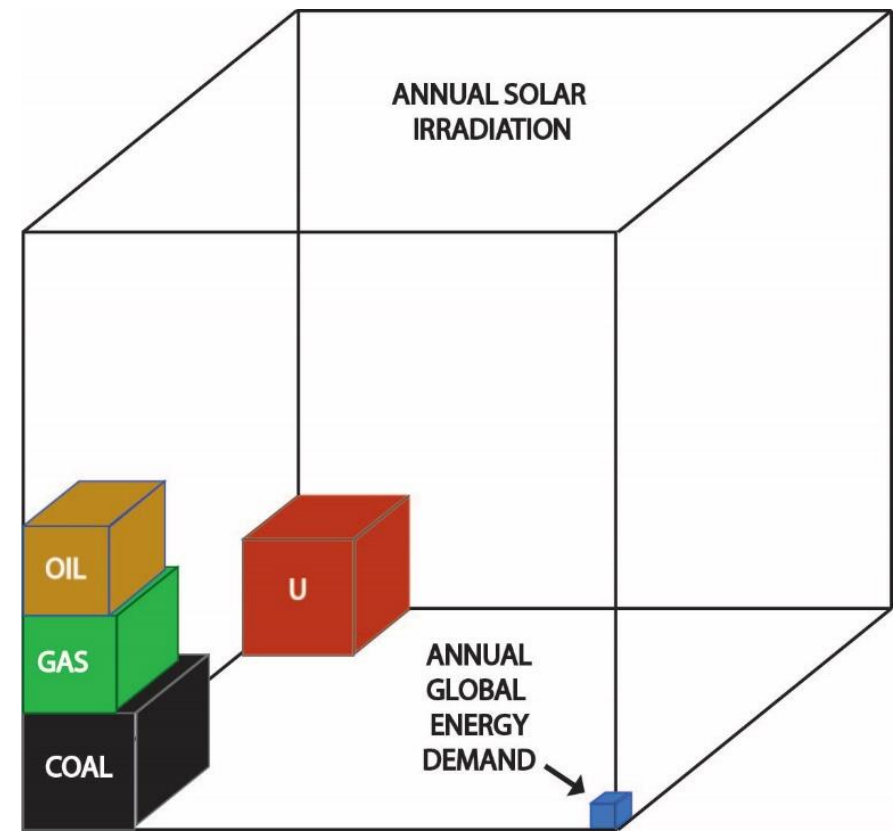

Figure 1 Total energy reserves of fossil fuels and uranium compared to total annual solar irradiance.

The sun provides 1750,000 TW of energy per annum. ${ }^{8}$ Solar panels at $10 \%$ efficiencies covering $0.48 \%$ of the land on earth can provide $60 \mathrm{TW}$ which will be double the projected demand. ${ }^{9}$ 
Silicon based photovoltaic devices are reaching efficiencies of $20 \% .{ }^{10}$ Silicon devices are the current market benchmark but silicon is an indirect-band gap absorber making it an inherently poor absorber of light; thus, these cells are designed to be opaque. Silicon based photovoltaic (PV) devices are costly to fabricate, hindering their competitiveness with fossil fuels. Silicon suffers in diffuse sunlight because it is not a direct absorber of light; it requires phonon assisted absorption. This hindrance allows for DSSCs to be competitive over silicon under ambient conditions.

A number of emerging photovoltaic technologies are shown in Figure 2. However, many of these utilize exotic and toxic materials creating concerns over the release of these materials into the environment and the effect on human health. ${ }^{11}$ Dye-sensitized solar cells (DSSC)s are an emerging next generation PV device which has reached current efficiencies as high as $15 \% .{ }^{12}$ 


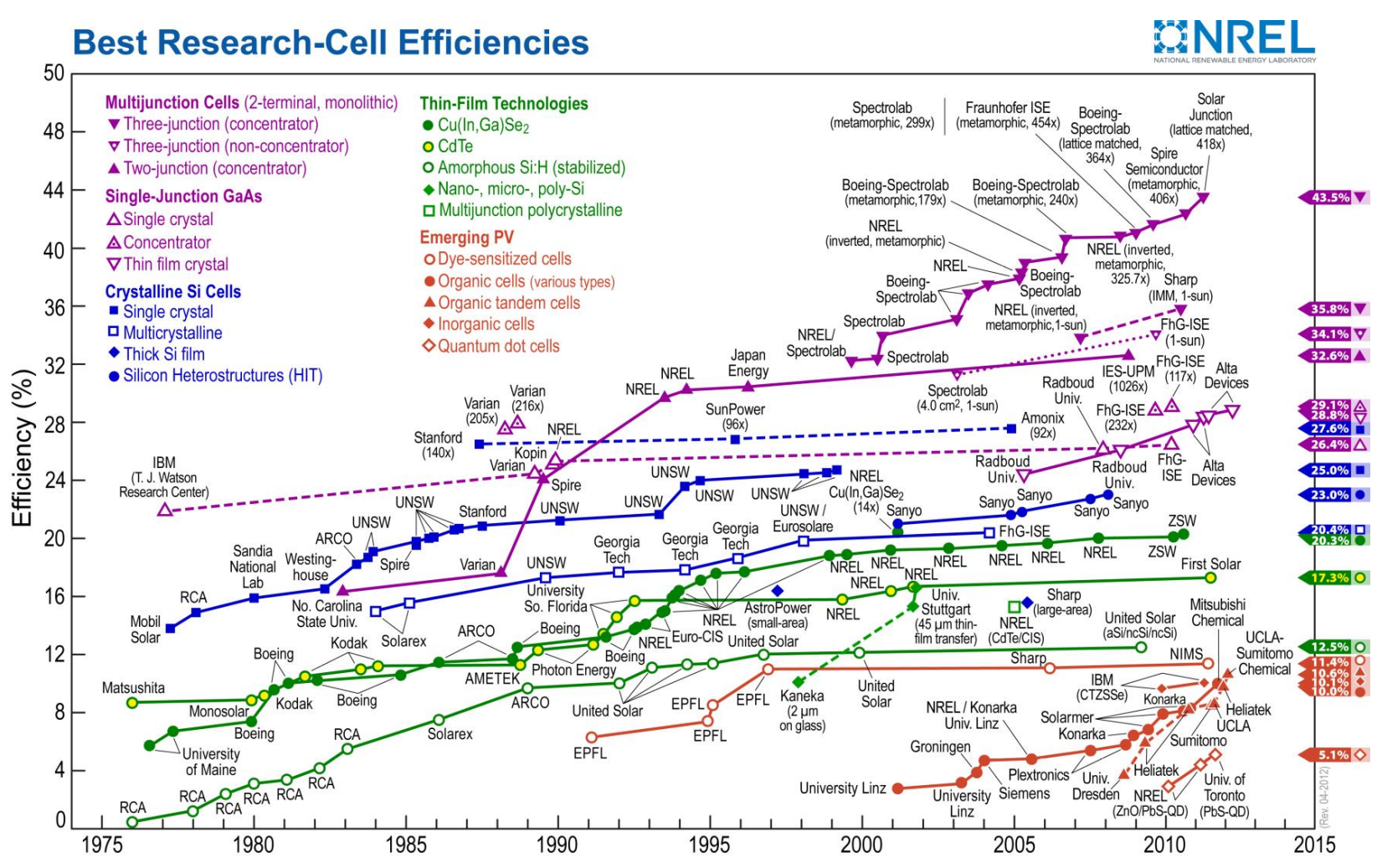

Figure 2 Efficiencies of current and emerging photovoltaic technologies.

It will be demonstrated in this thesis that despite the existence of other PV devices with significantly higher efficiencies, DSSCs compensate through ancillary advantages; the materials to fabricate are cost-effective ${ }^{13}$, readily available ${ }^{13}$ and are tunable to improve durability. Development of facile fabrication processes for DSSCs would make them commercially viable due to the low substrate cost. ${ }^{13}$

\subsection{Dye-Sensitized Solar cells}

Dye-Sensitized Solar Cells (DSSC) have multiple components that work synergistically to convert photon flux to electric current. The DSSC is comprised of a transparent photoanode base made from fluorine doped tin oxide (FTO) or indium doped tin oxide (ITO). ${ }^{8}$ Titanium dioxide (titania; $\mathrm{TiO}_{2}$ ) is usually sputtered onto the anode as a mesoporous layer. ${ }^{8}$ The titania is generally soaked in a solution containing a dye molecule which then binds to the titania semiconductor surface. ${ }^{14}$ The device is then sandwiched with a cathode made up of the same material as the anode. The anode 
must also be covered with a thin layer of platinum to catalyze the reduction of the electrolyte. DSSCS have a number of advantages over traditional silicon PV cells. They are diffuse light absorbers so they are more efficient than silicon PV devices under normal lighting conditions, but what is particularly novel about these devices are their design advantages over silicon; they can be fabricated as transparent, thin flexible devices.

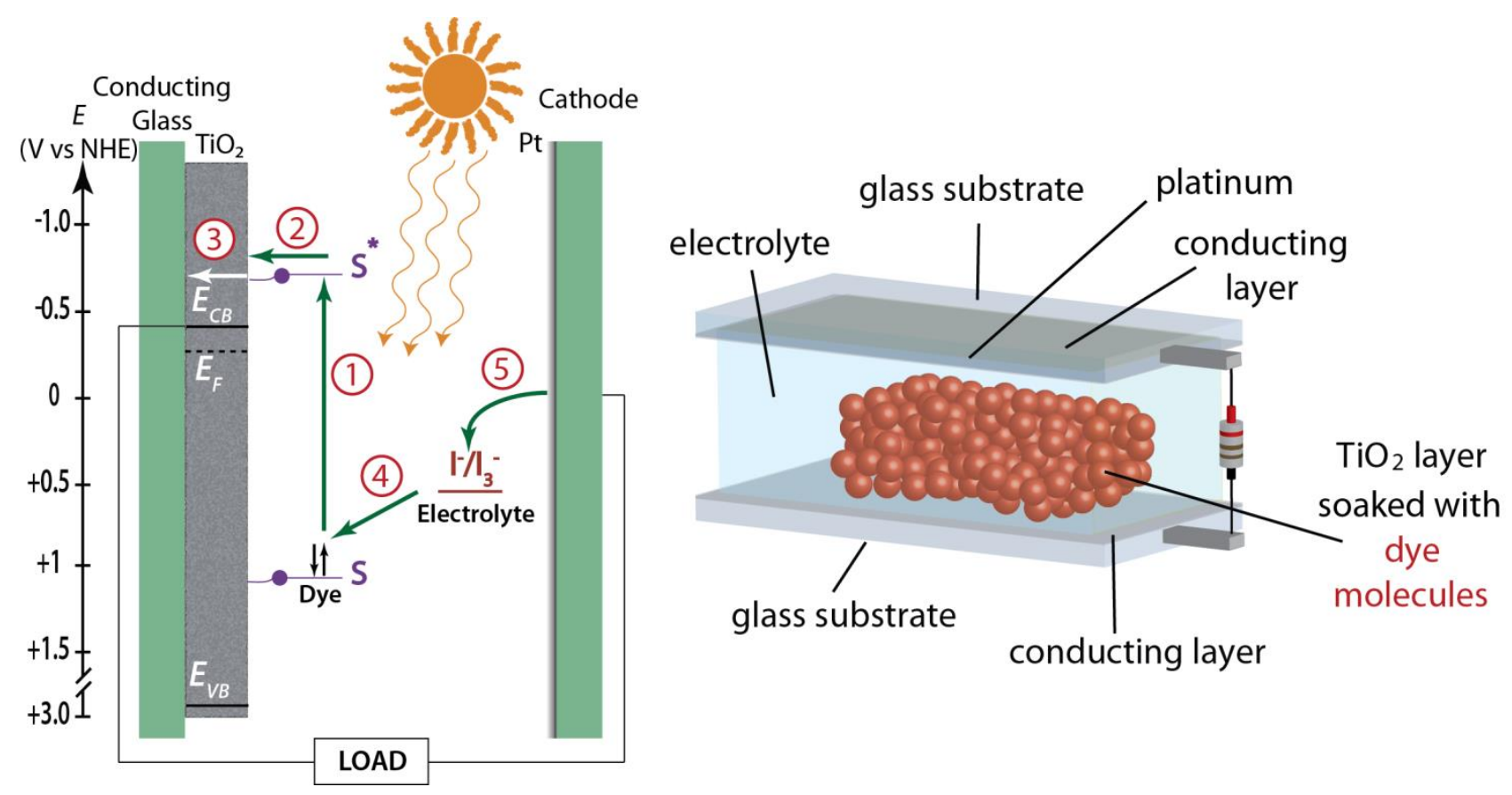

Figure 3 a)DSSC working principle. b) Device anatomy c) Formula for the efficiency of a cell: is the power conversion efficiency. $J_{s c}$ is the short-circuit current; proportional to the number of absorbed photons. $V_{o c}$ is the open-circuit potential which is equivalent to the difference in the energy between the electrolyte and the fermi energy level of the titania. The fill factor, $F F$, is a measure of the maximum potential of the cell. $\boldsymbol{P}_{\text {in }}$ is the incident power of light irradiated on the device.

The working principle of the DSSC Is illustrated in Figure $3 a:^{15}$ The first step involves absorption of a photon of light with sufficient energy (1) to excite the ground state of the dye ( $\mathrm{S} \rightarrow$ $\left.\mathrm{S}^{*}\right)$. The excited state $\left(\mathrm{S}^{*}\right)$ or the lowest unoccupied molecular orbital (LUMO) can inject this excited charge into the titania conduction band if a thermodynamic driving force exists (2). This injected charge permeates through the titania (3) after which the redox electrolyte regenerates the oxidized dye due to a thermodynamically favourable pathway $(4) \cdot{ }^{16}$ The redox pair then diffuses back to the 
platinized cathode to be regenerated (5). For proper charge injection, the LUMO of the dye molecule must overlap with the conduction band of the titania. The $J_{s c}$ is correlated with the extent of coupling to the titania. Coupling of the HOMO to the conduction band of the titania encourages further recombination (titania to dye).

Other thermodynamic and kinetic pathways are also available for electron flow and this serves to hamper efficiencies (Figure 4). In order for the device to work properly, d, must occur fast enough so that a short-circuit does not occur via electron transfer to the HOMO of the iodide/triiodide redox couple. ${ }^{8,17}$ If charge regeneration is slow or if there is good coupling between the HOMO of the dye to the titania conduction band, recombination of the injected charge back to the dye can occur $(\mathbf{g})$. The electrolyte/titania interaction, $\mathbf{f}$, is a common recombination pathway solved by utilization of an additive to passivate the surface and block electrolyte contact with the titania. ${ }^{18,19,20}$

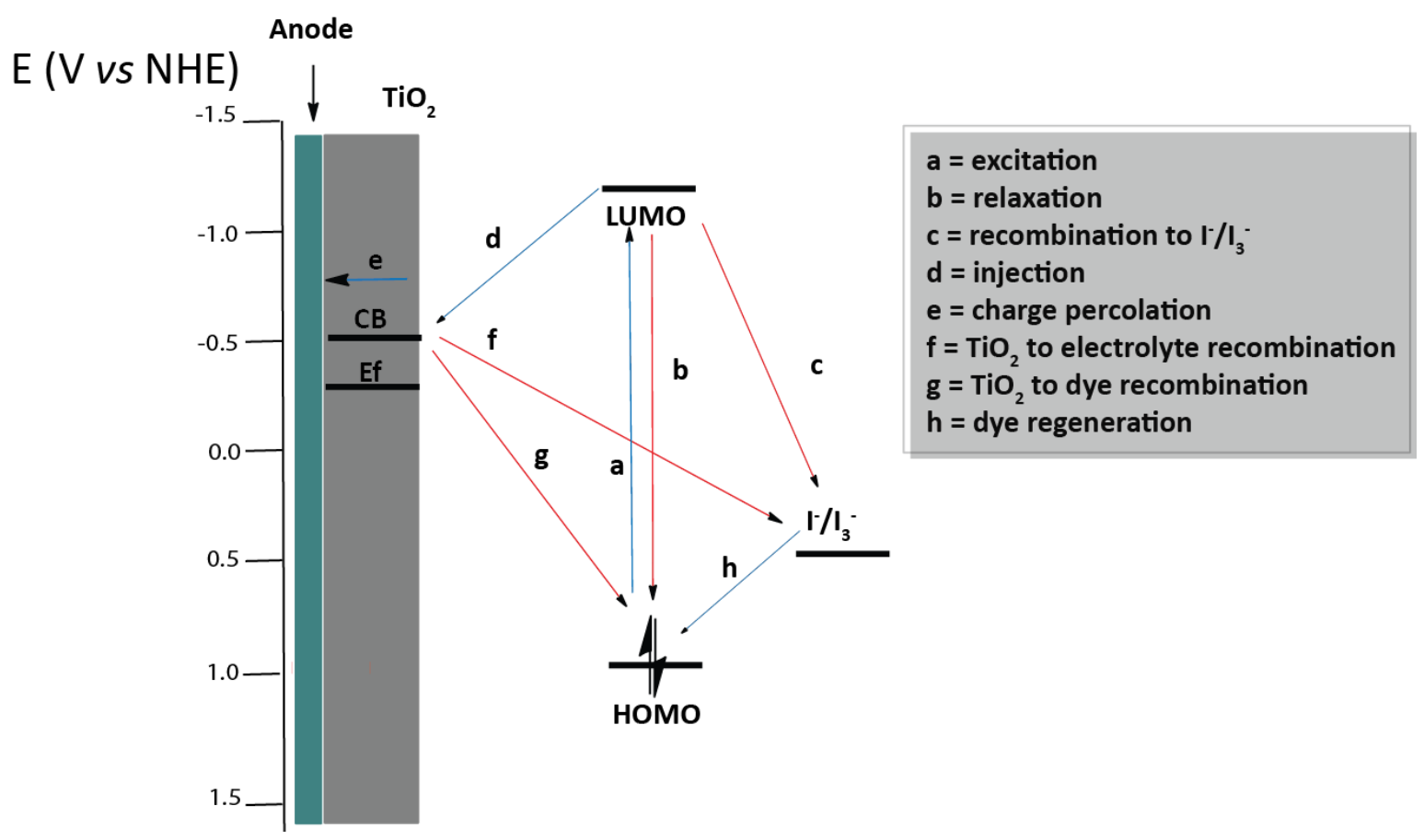

Figure 4 kinetically and thermodynamically favourable pathways for electron flow. 


\subsection{Molecular Characterization Techniques}

To design dye molecules that absorb strongly in the visible and near IR region of the electromagnetic spectrum they must have specific features. Generally these molecules incorporate a strong electron acceptor coupled to an redox-active electron donor. UV-Visible absorption spectroscopy is utilized to characterize dye molecules as candidates for DSSCs. A dye molecule's ability to absorb light in the visible spectrum can be understood with two graphical variables: the absorption profile (wavelength; abscissa) and the intensity for a given absorption (molar extinction coefficient $\varepsilon$; ordinate). Analysis can be performed to determine how well the molecule is absorbing light at regions of interest within electromagnetic spectrum. Figure 5 displays limited photon flux coming from the ultraviolet (UV) region whose flux is attenuated by the ozone in our atmosphere. So when UV-Vis spectroscopy is performed on a solution of a dye molecule of interest, it is important that the dominant absorptions are not significantly below $400 \mathrm{~nm}$.

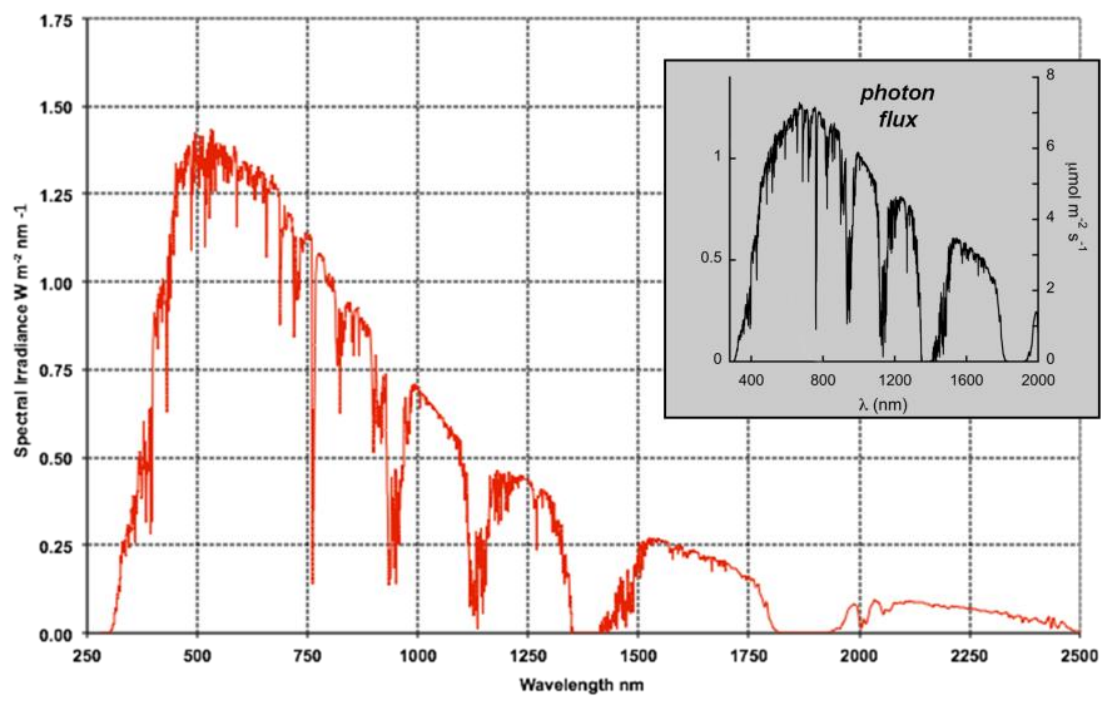

Figure $\mathbf{5}$ Solar irradiation and inset of the photon flux. 
Conjugated molecules can be modelled as a 1D particle in a box; $;^{21,22}$ so the wavelength of light that can be absorbed by a molecule is proportional to the extent of conjugation. Extension of the box leads to a decrease in the HOMO-LUMO energy gap (Figure 6).

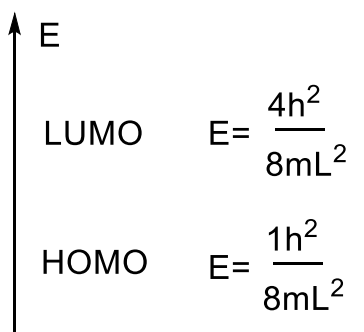

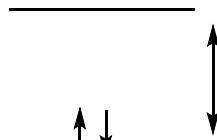

$\Delta \mathrm{E}_{1}$
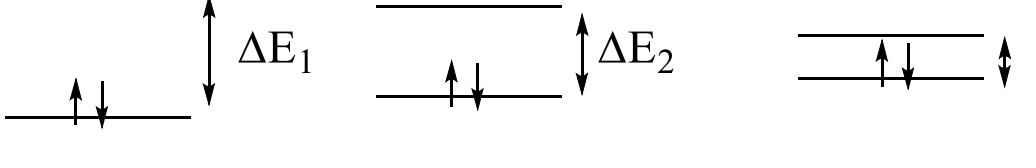

$\Delta \mathrm{E}_{3}$

$L$ increases

Figure 6 1D particle in a box model.

The fundamentals of light absorption and as a corollary the intensity of absorbed radiation, is quantified by the molar extinction coefficient $\varepsilon$. The molar extinction coefficient is composed of two parts: The optical cross-section and the probability of absorption. The optical cross-section is proportional to the hydrodynamic volume of the molecule. The probability of absorption is a quantum mechanical relationship between the ground and excited states of the molecule ( $\mathbf{S}$ and $\mathbf{S}^{*}$ ). The Frank-Condon principle ${ }^{23,22}$ states that the most probable absorption occurs between states with the best wave-function overlap since nuclear motion is considered negligible during photoexcitation. ${ }^{22}$ As shown in figure 7 , the polarizability $(\mu)$ operator represents a molecule's ability to undergo charge redistribution upon light absorption, but there is less wave-function overlap as charge redistribution increases. 


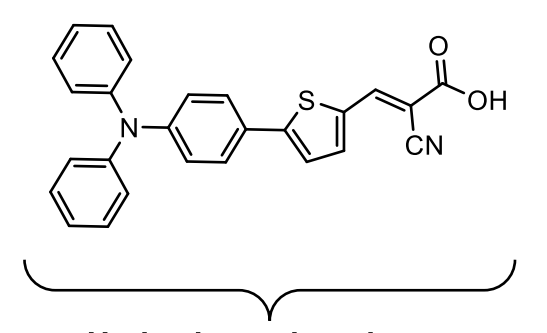

Hydrodynamic volume

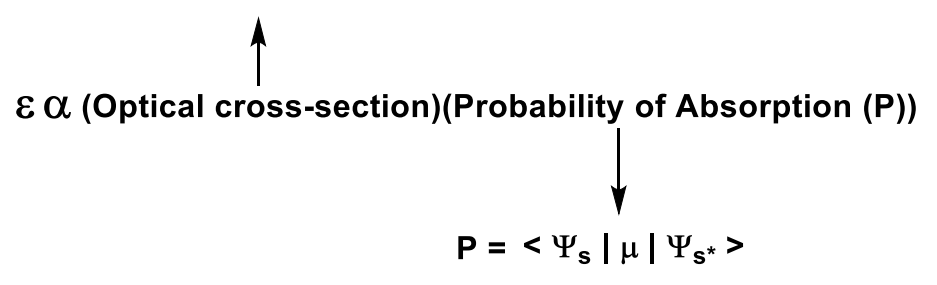

Figure 7 factors affecting the extinction coefficient show donor acceptor motif.

A $\pi$-spacer is a molecule used to increase the optical-cross section of a chromophore. ${ }^{24,25,26}$ If it can be conjugated with the bulk of the molecule, the energy of the chromophore can then be tuned to shift the absorption profile of the sensitizer.

Cyclic voltammetry (CV) is an electroanalytical technique used for the study of redox active analytes, which are quite ubiquitous. It is a quantitative and qualitative technique, which can be used to determine the formal potential of a half-reaction or the stability of a redox species, respectively. A reversible oxidation potential allows for the determination of the HOMO energy (highest occupied molecular orbital) and a reversible reduction allows for the determination of the LUMO (lowest unoccupied molecular orbital) energy; however, these are solvent dependent approximations. The HOMO-LUMO gap can be calculated by taking the difference between the HOMO and LUMO potentials (Figure 8). The experiment is carried out by applying a controlled potential to a sample having the shape shown in Figure 9. The potential is scanned towards a higher or lower potential (switching potential) then reversed; this can be repeated through multiple cycles into a negative or positive voltage region, hence, cyclic voltammetry. 


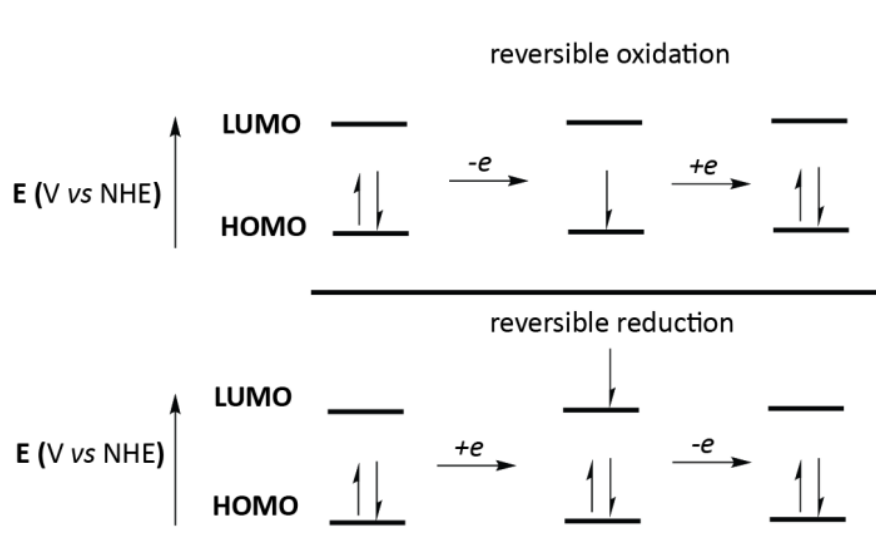

a)

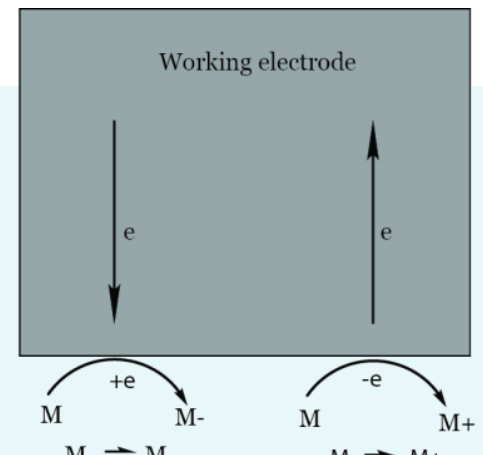

$M=M+$

Cathodic working mode Anodic working mode

$\mathrm{E}=\mathrm{E}^{\circ}-\frac{\mathrm{RT}}{\mathrm{nF}} \ln \frac{\mathrm{M}_{\mathrm{a}}}{\mathrm{M}-\mathrm{a}_{\mathrm{a}}} \quad \mathrm{E}=\mathrm{E}^{\circ}-\frac{\mathrm{RT}}{\mathrm{nF}} \ln \frac{\mathrm{M}_{\mathrm{a}}}{\mathrm{M}+_{\mathrm{a}}}$

Nernst equations

b)

Figure 8 a) Mechanism of oxidation and Reduction processes at the frontier molecular orbitals. b) Illustration of redox processes occurring at the working electrode.

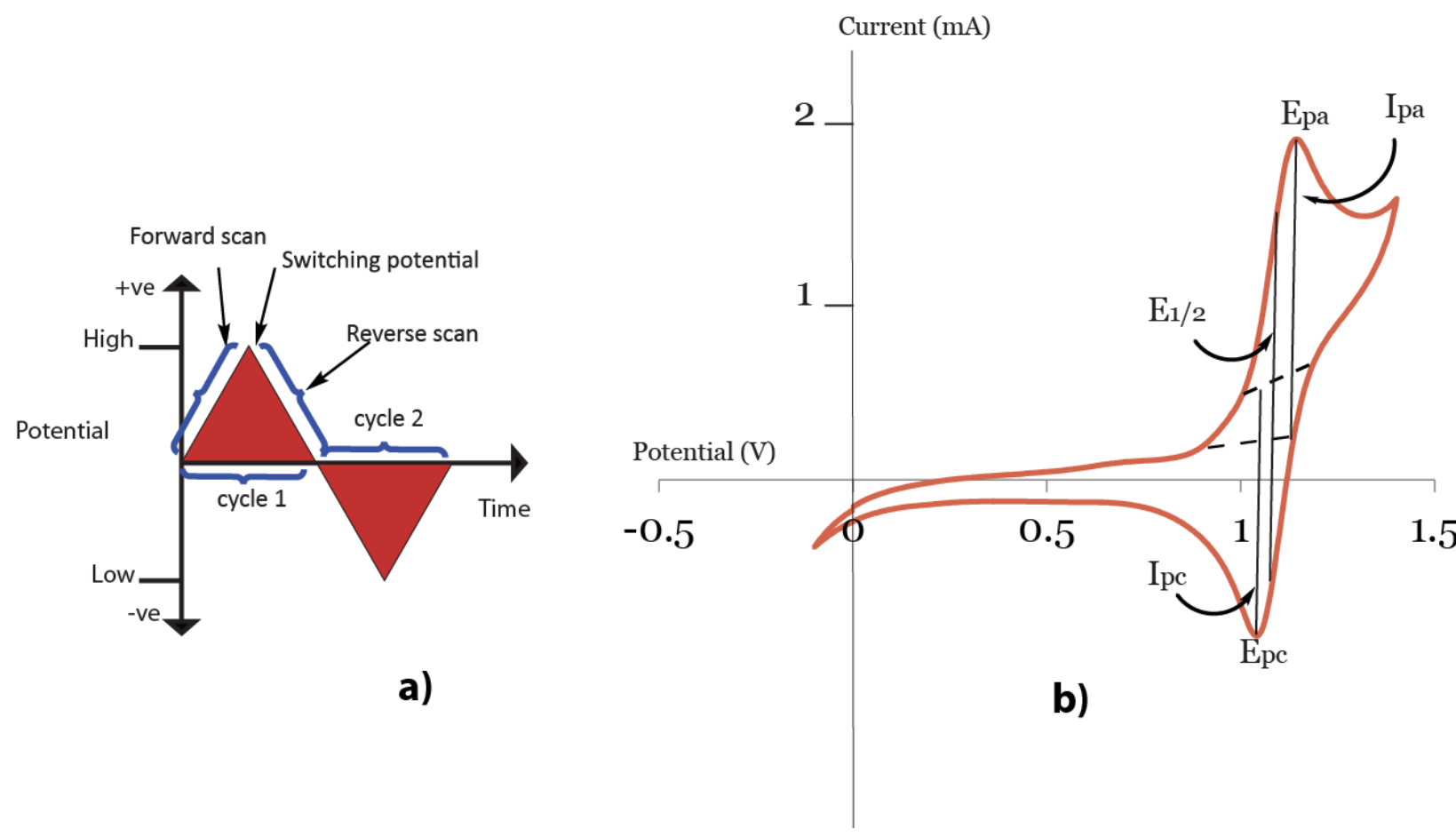

Figure 9 a) Cyclic voltammetry potential wave form. b) Example CV of a dye designed in the Koivisto group. ${ }^{27,28}$

A cyclic voltammetry experiment is carried out with three electrodes inserted into a cell containing a solution and connected to a potentiostat (Figure 8). Electrodes must be chemically inert to discourage reactions with species in solution, especially the analyte. The Ag reference electrode 
used with a potentiostat is a "pseudoreference." Ferrocene is added as an internal standard to calibrate redox potentials. ${ }^{29}$ The solution consists of a supporting electrolyte and the analyte ( $\mathrm{M}$ in figure 8). The solvent must have an electrochemical window larger than the potential region which the sample is run through: the electrochemical window is the voltage region at which a chemical species (or solvent) does not engage in redox processes. DMF, MeCN and DCM are suitable organic solvents for studying the redox properties of organic molecules: They have good solubility (for both the supporting electrolyte and many organic molecules), they are not Lewis basic and they have a wide electrochemical window. DCM is particularly suitable because it solubilizes the majority of molecules prepared in our group very well and to make valid empirical observations, all electrochemical experiments should be performed in the same medium. The supporting electrolyte is required to maintain a current through the solution; solvents such as dichloromethane are not conductive. A wide electrochemical window is also a requirement for the supporting electrolyte.

A potential-current curve, the cyclic voltammogram (Figure 9), is generated through the utilization of a potentiostat, which varies the potential of the working electrode with respect to the reference electrode. ${ }^{29,30,29}$ All redox processes involving the analyte occur at the surface of the working electrode (Figure 8). ${ }^{31,29,25}$ The counter-electrode is required to complete the circuit; during the working electrodes anodic (oxidative mode) sweep, the counter-electrode acts as a cathode (reductive mode) and vice versa. The CV in Figure 9 begins by increasing the potential in the positive direction; the current rises as sufficient potential is reached to oxidize the analyte, climaxing at the anodic peak $\left(E_{p a}\right)$. The current then decays as the rate of diffusion of $M$, to the working electrode decreases. ${ }^{29}$ The working electrode then enters a cathodic mode at the switching potential and the voltage decreases to reduce the oxidized species $(\mathrm{M}+) .{ }^{29}$ On the reverse scan, the current reaches its maximum at the cathodic peak $\left(E_{p c}\right)$; the cathodic current then decreases as the rate of diffusion of 
$M+$ to the working electrode decreases. ${ }^{31}$ The formal redox potential $\left(E_{1 / 2}\right)$ is determined by calculating the average of the anodic and cathodic potentials. A reversible redox process will see a separation between the anodic and cathodic peaks of $57-58 / n \mathrm{mV},{ }^{30,29}$ where $\mathrm{n}$ is the stoichiometry of electrons in the half-reaction (Equation 1): for a multi-electron process the separation will decrease. Another condition for reversibility is that the ratio of the anodic $\left(I_{\mathrm{pa}}\right)$ and cathodic current $\left(I_{p c}\right)$ should be close to unity $\left(I_{p c} / I_{p a}=1\right) .{ }^{28}$ Reversible behaviour is obtained when the concentrations of the oxidized and reduced forms of the analyte are at equilibrium for a given potential set by the Nernst equation (Equation 1). ${ }^{3.6}$ To maintain equilibrium, half-reactions must occur fast enough at the electrode; if the scan speed is too fast ( $>100 \mathrm{mV} / \mathrm{s}$ ) the current peak (cathodic current in the case of Figure 9) would occur at an higher potential, thus increasing the separation between the cathodic and anodic peaks. If a reaction occurs to convert $\mathrm{M}+$ to a side-product, the cathodic current peak will be diminished and reversibility will be affected.

\subsection{Dye Architecture}

The dye motif in DSSC's follows a strict design profile which facilitates charge transfer and light absorption which is key for efficient current generation. ${ }^{8}$ The previous section elucidated on how molecules absorb light; the molecule must be polarizeable so an electronegativity gradient must be induced through judicious functionalization. The anchoring groups on a DSSC are electronwithdrawing so electron density upon excitation can be redistributed towards the titanium dioxide. ${ }^{32,17}$, The donor in turn must be electron rich. Through this polarization, charge injection can be induced towards the conduction band of the titania.

\subsection{Donor}

The donor of a DSSC must satisfy two properties: they must non-planar and electron rich. ${ }^{8,33}$ If they are planar then $\pi$-stacking will occur which will lead to dye-aggregation and in turn quenching of 
photo-activation. ${ }^{33}$ For this, heteroatoms are frequently employed (Figure 10). Side groups like hexyloxy groups are furnished onto the donors to prevent aggregation and inhibit electrolyte migration to the titania. ${ }^{34}$ This facilitates solubility in organic solvents as well; by contrast the carboxylic acid moieties affixed as an anchoring group reduces solubility drastically.<smiles>CC(C)(C)c1ccc(N(c2ccccc2)c2ccccc2)cc1</smiles><smiles>CC(C)(C)c1ccc(C=C(c2ccccc2)c2ccccc2)cc1</smiles><smiles>Cc1ccc2c(c1)Sc1ccccc1N2C</smiles><smiles></smiles><smiles>CC1CC2C(C)CC(C)C2C(C)C1C</smiles>

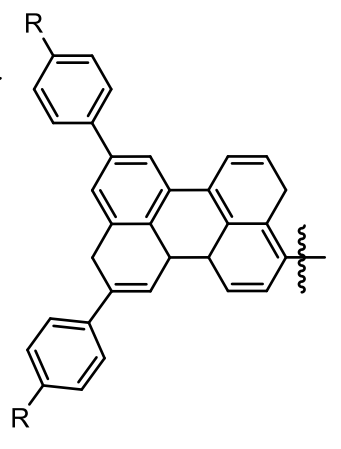

Figure 10 Catalogue of common donor moieties.

\subsection{Triphenylamines}

Triphenylamines are seeing extensive use in materials applications due to their electronic properties; ${ }^{35,36}$ they are easily oxidizable and the aminium cation formed upon oxidation facilitates hole-transfer. Their propeller like geometry comes from the steric repulsion between the phenyl rings giving them a dihedral angle of $120^{\circ}$. As expanded on previously, this geometry makes them ideal donor candidates. In addition simple adjustments can be made to tune TPA's absorption spectrum into the visible spectrum of light. FormyITPA has an orange colour and diformyITPA is yellow (Figure 12). 

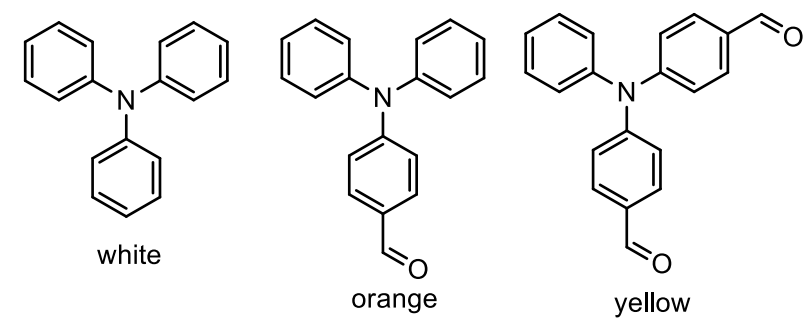

Figure 11 Image of TPA (white), formylTPA (orange) and diformyltpa(yellow).

Derivatives of TPA can be designed to act as chromophores in DSSCs and have shown relatively high efficiencies. ${ }^{24}$ Their electronic properties are also tunable. Functionalization of the para-positions causes noticeable changes in the oxidation potentials (Figure 12). The aminium cation of TPA also has the potential to dimerize. This coupling process can be mitigated by blocking the para-positions or by incorporation of electon-rich substituents to stabilize the radical cation. ${ }^{37}$

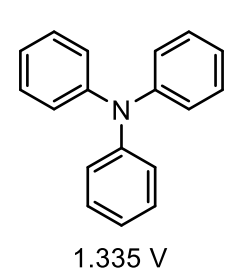<smiles>COc1ccc(N(c2ccccc2)c2ccc(OC)cc2)cc1</smiles><smiles>CC(C)(C)C(C)(C)C</smiles><smiles>N#C/C(=C\c1ccc(-c2ccc(N(c3ccccc3)c3ccccc3)cc2)s1)C(=O)O</smiles><smiles>COCCOc1ccc(N(c2ccc(Br)cc2)c2ccc(Br)cc2)cc1</smiles><smiles>COCCOc1ccc(N(c2ccc(Br)cc2)c2ccc(OCCOC)cc2)cc1</smiles><smiles>COCCOc1ccc(N(c2ccc(OCCOC)cc2)c2ccc(OCCOC)cc2)cc1</smiles>

Figure 12 Electrochemically characterized TPA derivatives synthesized in our lab. Oxidation potentials labelled below each TPA analogue (V vs NHE).

The Koivisto group utilizes a number of TPA derivatives as electron rich donors in sensitizer candidates, notably, bis-hexyloxyTPA and bis-methoxyTPA. Two common methods for synthesizing 
TPA analogues are Buchwald-Hartwig and Ullmann coupling. ${ }^{29}$ At this time, the Koivisto group only employs the Ullmann coupling experimental protocols. The use of TPA in many current research projects has motivated the group to optimize a protocol for TPA synthesis. The reaction protocol used in our group involves the coupling of an arylhalide and an arylamine (Figure 13).

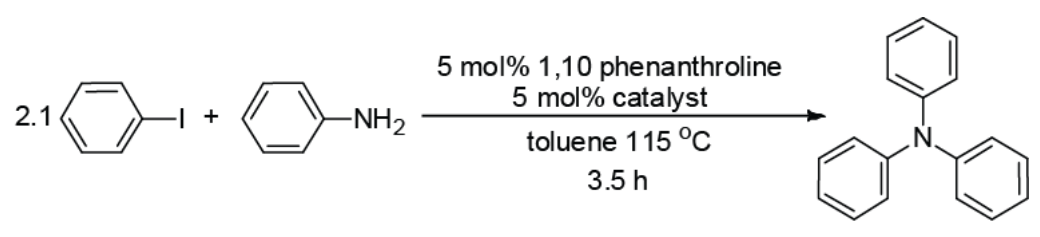

Figure 13 Ullmann coupling reaction protocol to synthesize TPA. ${ }^{29}$

\subsection{Anode}

To bring out the potential of DSSC's as an improved light-harvesting device, research into semiconducting oxides which contain a porous morphology were developed. Rough surface morphologies were motivated by the low light-harvesting yields $(<<1 \%)$ produced even with high extinction coefficient dyes such phthalocyanines and porphyrins. ${ }^{8}$ These low efficiencies are created by low dye loading on the surface of the semiconductor; this results in a drop in light-harvesting ability. In the seminal paper by O'Regan and Gratzel in 1991, an efficiency of 7.1-7.9\% was achieved using a mesoporous semiconductor electrode. ${ }^{8}$

Many metal oxide systems exist for use in DSSCs: $\mathrm{TiO}_{2}, \mathrm{ZnO}, \mathrm{SnO}_{2}, \mathrm{Nb}_{2} \mathrm{O}_{5}, \mathrm{SrTiO}_{3}$ and $\mathrm{Zn}_{2} \mathrm{SnO}_{4}{ }^{8,38}$ Early studies focused on $\mathrm{ZnO}$ as the semiconductor component in DSSCs. The chemical stability of $\mathrm{ZnO}$ is weak due to its easy solubility in acidic and basic conditions. In spite of these shortcomings, research into the use of $\mathrm{ZnO}$ has continued unabated for practical reasons; various crystalline morphologies in its wurtzite form are easy to synthesize. Chemically stable $\mathrm{SnO}_{2}$ has a particularly low conduction band level. This makes it useful for dyes with low lying LUMOs but the $V_{o c}$ suffers for it and efficiencies above $2.8 \%$ are difficult without a $\mathrm{ZnO}$ coating. ${ }^{8}$ 
Titania $\left(\mathrm{TiO}_{2}\right)$ is a stable semiconducting oxide with a high refractive index. It has applications in sunscreen, toothpaste, paint, self-cleaning materials, and food. Its non-toxic nature amplifies the "green" nature of DSSCs. It has three relevant crystal forms: rutile, anatase, and brookite. ${ }^{8}$ Though rutile is the most thermodynamically stable crystal, anatase is more prominent in DSSC literature because of the larger band gap which inhibits competitive visible light absorption with the sensitizer. The conduction band edge energy is also the highest in the anatase form which allows for a higher $V_{o c}{ }^{8} \mathrm{~A}$ number of anatase structures have been developed to improve dye loading; methods include the development of nanotube array architectures. The pore sizes can be controlled allowing a diameter of 12-240 $\mathrm{nm}$ each as well as using hierarchical organized electrodes. ${ }^{8}$

\subsection{Cathode}

Several counter-electrode materials are available to catalyze the reduction of triiodide. They have achieved charge transfer resistances lower than $<1 \Omega \mathrm{cm}^{-2} .8$ Platinum is a common electrode for DSSCs to catalyze the series of redox reactions that iodide/triiodide engage in. Counter-electrodes in DSSCs are coated with a thin layer of catalytic platinum prepared via deposition using electrodeposition, spray pyrolysis, sputtering and/or vapour deposition. A thin layer $\left(5 \mu \mathrm{g} \mathrm{cm}^{-2}\right)$ of platinum is required to maintain the transparency of the device. Spray pyrolysis and sputtering are preferred methods due to the dissolution of the Pt film in the iodide/triiodide solutions prepared through the other methods. ${ }^{8}$ Cobalt sulfide has outperformed Pt recently even with other electrolyte systems. Carbon based materials such as a mixture of carbon black and graphite are used for the reduction of triiodide. An extra layer of carbon materials are used after the first layer adheres to the substrate to enhance the catalytic effect. Doped PEDOT with toluenesulfonate anions show excellent performance in devices. Other conductive polymers such as polyaniline, polypyrrole were considered unsuitable when studied as electrodes. ${ }^{8}$ 
In spite of the performance of each counter-electrode, it would be beneficial to make it redundant so cost of fabrication can be lowered and the device architecture can be simplified. The development of new solid state devices utilizing hole-transport materials as a replacement of the liquid iodide/triiiodide redox system will lead toward this goal.

\subsection{Electrolyte System}

The iodide/triiodide redox couple is commonly used in $\mathrm{DSSCs}^{16}$, premiering in the original Grätzel paper in $1991 .{ }^{39}$ The original solution was formulated as a mixed solvent system solvent (80:20; ethylene carbonate:MeCN). ${ }^{39}$ The electrolyte compositions were $0.5 \mathrm{M}$ tetrapropylammonium iodide and $0.04 \mathrm{M}$ iodine. A diverse range of additives and solvents have been employed since then to vary solution viscosity and tune charge dynamics. The solvents used for liquid based electrolytes must be non-protic to avoid hydrolysis of the cyanoacrylic acid moieties commonly used as anchoring groups. ${ }^{8}$ Solvent selection must allow for solubilisation of the electrolyte but not the dye molecule itself anchored to the titania substrate. Early solvents used carbonates but due to the low solubility of the redox couple, highly polar nitrile based solvents were employed. ${ }^{8}$

Hole-transport materials (HTM's) are a promising alternative electrolyte system to the iodide/triiodide redox pair. This is motivated by a need to develop a solid state device due to the inherent instabilities of a liquid electrolyte system. The liquid electrolyte destabilizes the device through evaporation of the solvent, leakage of the solution through gaps in the sealant and degradation of the electrodes. ${ }^{8}$ A key advantage HTMs have are their fast charge-transfer kinetics. Hole-transfer from the dye to the HTM and regeneration of the dye by the $\mathrm{I}^{-} / \mathrm{I}_{3}^{-}$redox pair are $<1$ and 400 microseconds, respectively. The essential requirements of HTM's are: quick transfer of holes to 
the sensitizer, it must be able to infiltrate the pores of titania after deposition, it must not disturb the dye monolayer and it should be transparent to visible light. ${ }^{8}$

Inorganic p-type electrolytes such as $\mathrm{CuBr}$, Cul and CuSCN were one of the earlier adoptees for DSSCs that satisfied all of the key characteristics of an HTM. ${ }^{8}$ The conductivities of Cul and CuSCN are in excess of $10^{-2} \mathrm{~S} \mathrm{~cm}^{-1}$ which is an advantage for their hole-conducting ability. Solid state devices incorporating Cul reached high current flux $\left(1.5-2.0 \mathrm{~mA} \mathrm{~cm}^{-2}\right)$ for their class but their efficiencies were still low overall (2.4\%). The durability of DSSCs employing Cul is low. The degradation occurs at a faster rate than in liquid state DSSCs; under continuous illumination Cul undergoes oxidative processes. Solution deposition of Cul produces large crystallites that do not penetrate the pores of the titania, ${ }^{8}$ reducing dye regeneration and amplifying recombination.

Ionic liquid electrolytes were an early alternative to the $\mathrm{I}^{-} / \mathrm{I}_{3}^{-}$liquid electrolyte system because of their durability. ${ }^{8,40}$ They are non-flammable, have a wide electrochemical window, high conductivity and have decent thermal and chemical stability. They suffer from viscosity issues which lead to sluggish charge transport of the triiodide. ${ }^{8}$ Stability has gone up but the issue of electrolyte diffusion from the cathode to the dye itself is still a concern. These are mitigated by applying a higher concentration of triiodide. $^{8}$

Organic and polymeric hole-transport materials are emerging as strong competitors to all other types of hole-transport systems. They combine the durability of ionic liquid electrolytes with the high conductivity of inorganic $p$-type semiconductors. The most efficient organic HTM is $2,2^{\prime}, 7,7^{\prime}-$ tetrakis(N,N-di-p-methoxyphenylamine)-9,9'-spirobifluorene (spiro-OMeTAD). Devices utilizing SpiroOMeTAD have performed at $7.2 \%$ but they require chemical dopants to reach an efficiency that high. ${ }^{8}$ However, their inability to easily infiltrate the pores of titania and their low conductivity exclude 
them from being ideal candidates. Other organic HTMs attempt to compensate by reducing the hydrodynamic volume of the molecule to improve pore filling and solubility.

Polymer based HTMs which can be in-situ generated in the pores of titania, avoid the problem of poor pore-filling. Polypyrrole doped with $\mathrm{LiClO}_{4}$ was the first conductive polymer studied for use in DSSCs. Their performance was disappointing $(0.1 \%)$ but with a modified carbon counter-electrode, they have reached modest efficiencies. Figure 14, displays the polymer options available for conducting polymers but PEDOT ${ }^{41,42}$ is the current champion due its high thermal and redox stability, transparency and high hole conductivity $\left(300 \mathrm{~S} \mathrm{~cm}^{-1}\right)$.
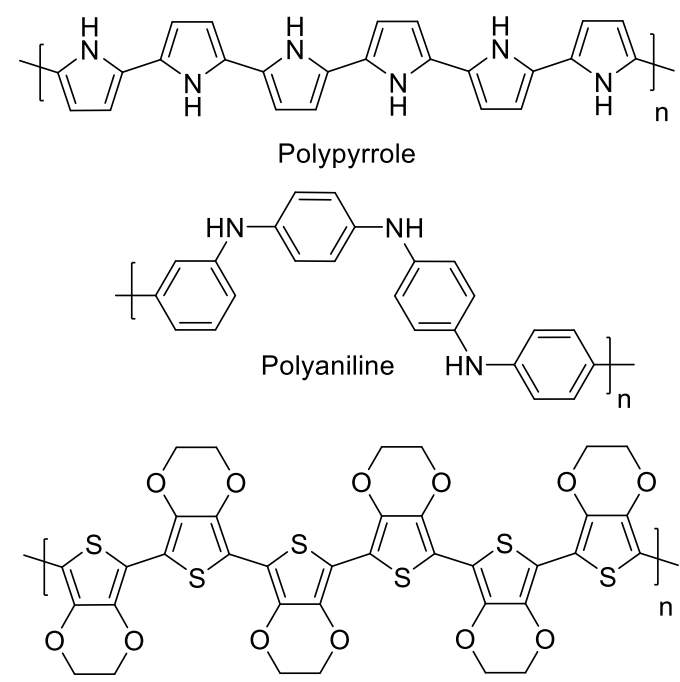

Poly-3,4-ethylenedioxythiophene

Figure 14 Conducting polymers.

\subsection{Objectives: Towards durable devices and panchromatic absorption.}

The objective of my research project was to engineer a dye system utilizing fundamental concepts of light absorption and selecting the proper donor moiety to build a multichromic and robust molecular architecture. In the manuscript ${ }^{25}$ I contributed towards, TPA donors that were modified with pendant thiophene arms were utilized. Thiophene functionalized TPA showed 
favourable light-harvesting capabilities over the unmodified benchmark dye molecule (discussed below). It is proven experimentally in our findings that they can be in-situ polymerized with an HTM. However, these dyes are not novel enough as they are too similar to the benchmark dye in their structure so a novel family of light-harvesting agents that can be integrated with an HTM must be designed.

Dye molecules utilizing a D- $\pi-A$ (donor- $\pi$ spacer - acceptor) motif are optimal because their polarization facilitates light absorption. These structures, however, have narrow absorption profiles. The idea of cosensitization has appeared in the literature to achieve panchromatic absorption by utilizing dye molecules with complementary UV-Vis absorption profiles on the same titania surface. High efficiencies were reported utilizing this method but this is due to replacement of the chenodeoxychlic acid coadsorber, which is used to block electrolytes from the surface of the titania. ${ }^{8}$ This method is a roundabout method of achieving panchromatic absorption and does not mitigate certain concerns and limitations; the absorption profiles of the cosensitizing dyes must not be entirely complementary or regions of low intensity absorptions will exist. Cosensitization also leads to reduced concentrations of the dye molecules due to the surface area restrictions of the titania. ${ }^{43} \mathrm{An}$ innovative cosensitization technique developed by Abbotto et $a f^{43}$ involves the design of an asymmetric dye motif that is tribranched and composed of two different dye molecules linked together by a vinyl bridge (Figure 15). The UV-Vis profile of the tribranched dye was discovered to be a combination of the symmetric tribranched motifs (both $\pi$-spacers being the same, benzene or thiophene). The authors performed a physicochemical comparison of the asymmetric and symmetric tribranched dyes but did not compare it with dyes L1 and TC105 which are their constituents. ${ }^{44}$ The lack of this comparison is odd given that the effects of cosensitization could have been more easily observed. 


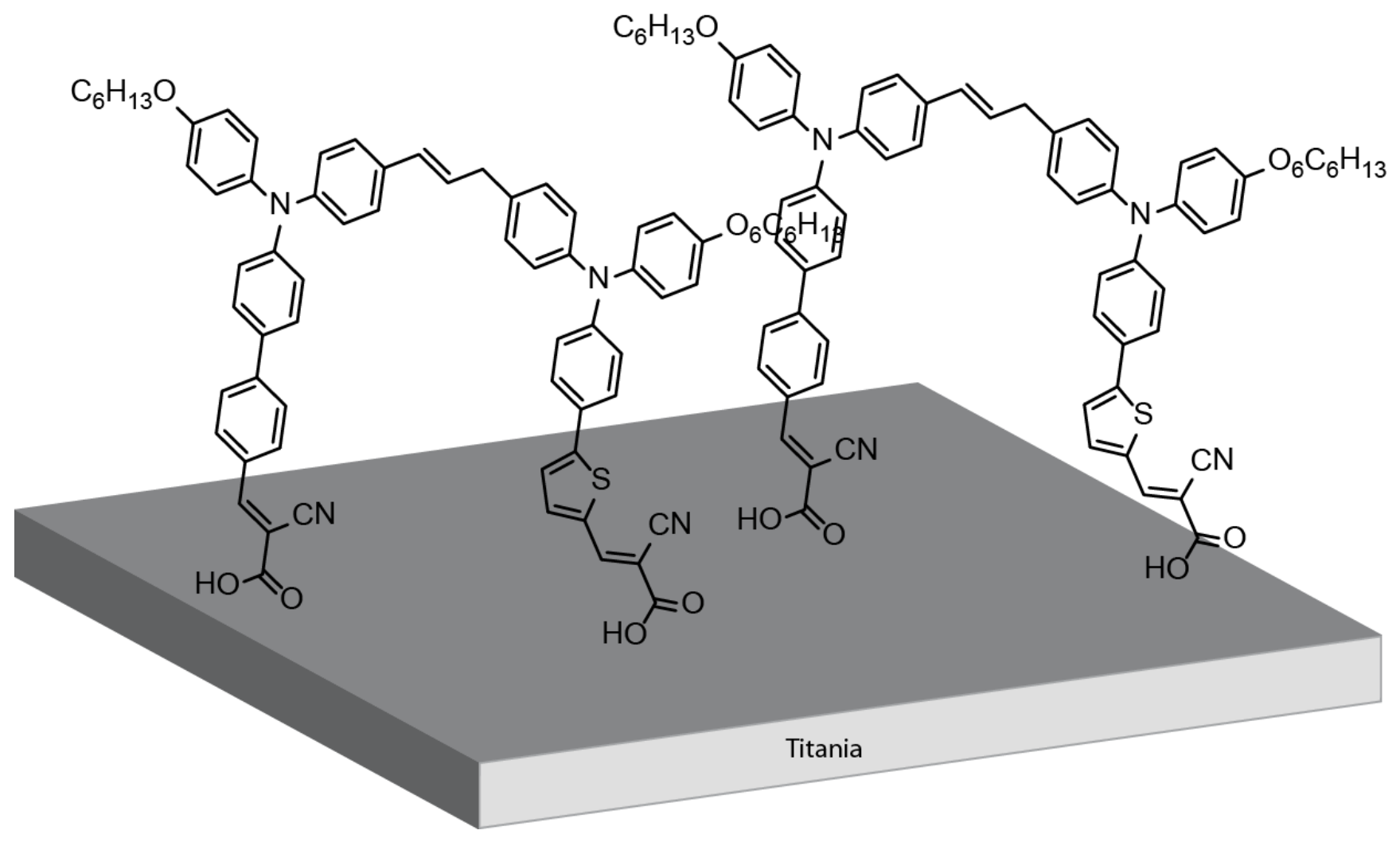

Figure 15 Asymmetric tribranched dyes. ${ }^{44}$

Despite the slight improvements in the efficiency, reducing the surface area of the mesoporous titania surface available for dye molecules shunts the potential of the device. Greater efficiencies can be realized by engineering the dye to be multichromic. What this means from a molecular point of view is that the sensitizer can be furnished with multiple donors instead of just one. The objective of my thesis thesis project was to investigate the light-harvesting capabilities of a bichromic and bipodal system that can be united with the goals of our previous paper. The inclusion of an extra anchoring group should serve to increase stability of the dye on the titania surface through increased adhesion. Through an improved dye/titania adhesion, the dye loading should be increased and current generation should improve over monopod dyes. The addition of an ancillary donor unit should serve to increase the absorption envelope and increase the short-circuit current as well. 


\section{Chapter 2: The Effect of Donor-modification in Organic Light-harvesting Motifs:}

\section{Triphenylamine Donors Appended with Polymerisable Thienyl Subunits.}

\section{1: Intent of the work}

This manuscript presents a family of triphenylamine-based dyes that have been investigated as a route towards integration with an HTM. Triphenylamines are functionalized with thiophene groups that can engage in in-situ electropolymerization. It is hypothesized that this integration will lead to reduced impedance and an improvement in device stability.

\section{2: Significant Outcomes}

The family of dyes that incorporated pendant thiophene arms showed decent performance when utilized in devices (5.51-6.56\%). Disubstituted triphenylamines showed the best performance. Cyclic voltammetry experiments have confirmed the ability of these dyes to engage in stable electropolymerization.

\section{3: Contributions by the authors}

Dr. Catherine Bonnier contributed towards the vast majority of the synthetic work in this manuscript. Devin D. Machin fabricated devices to characterize their performance. I have assisted Dr. Bonnier with producing building block molecules and also performing electrochemical and UV-Vis experiments to determine the physicochemical properties of our dye candidates

\section{4: Manuscript}

A family of seven organic triphenylamine-based dyes suitable for dye-sensitized solar cell (DSSC) applications are reported. The donor portion of these dyes has been systematically modified using polymerisable thienyl subunits. The physicochemical properties and device performance is discussed with device efficiencies range from $5.51-6.65 \%$ which exceeds the benchmark efficiency. 
While dye-sensitized solar cells (DSSCs) have attracted growing interest because of their ease of fabrication and low-cost, there are still significant problems with the commonly employed $1 / \mathrm{l}_{3}{ }^{-}$ liquid electrolyte, ${ }^{1}$ namely; the $\mathrm{I}^{-} / \mathrm{I}_{3}^{-}$electrolyte corrodes metal contacts and electrodes; $\mathrm{I}_{3}{ }^{-}$partially absorbs visible light; ${ }^{2}$ the electrolyte itself photodegrades; the presence of small amounts of $I_{2}$ can interact with or decompose the dye $\mathrm{e}^{3}$ and because of the volatile nature of the electrolyte solution only finite temperature ranges may be tolerated for cell operation. These limitations are partially responsible for long-term stability and performance issues and ultimately the wide spread applicability of DSSCs. To avoid these problems a new electrolyte is required. Recent work has focused on alternative redox couples, ${ }^{2,}{ }^{4}$ ionic liquids, ${ }^{5}$ and solid-state ${ }^{6}$ or polymer hole transport materials ${ }^{7}$ (HTM). Polymer-based HTM's are particularly attractive due to their rapid hole mobility, and polyethylenedioxythiophene (PEDOT) has been shown to be an effective HTM in DSSCs. ${ }^{7,8}$

Concomitantly, organic-based photosensitizers have become increasing popular for lightharvesting applications owing to an improved understanding of the requisite structure property relationships. ${ }^{9}$ For example, all organic dyes for DSSC applications are comprised of a redox-active donor/chromophore (D) that is coupled through a $\pi$-conjugated spacer to an acceptor (A) capable of anchoring to $\mathrm{TiO}_{2}{ }^{9,}{ }^{10}$ Furthermore, there has been an increasing number of examples that suggest organic dyes can be systematically tuned ${ }^{11,12}$ to have improved interactions with $\mathrm{I}^{-} / \mathrm{I}_{3}{ }^{-}$, and in many cases can outperform their ruthenium-based counterparts when using novel electrolytes. ${ }^{4,7,8}$

While much of the synthetic efforts have been placed on developing unique $\pi$-spacers capable of increasing charge separation and bathochromically shifting the absorption profile, ${ }^{13,}{ }^{14}$ the modification of the redox-active donor with electron-rich $\pi$-systems has been less studied. ${ }^{15-17}$ 
Triphenylamines (TPAs) are the most commonly employed donors in organic motifs because of their intense absorption and rich redox behaviour. ${ }^{18}$

Our motivation for this work began with a report by Liu and Ramakrishna, where they found that an indoline-based dye could effectively sensitize $\mathrm{TiO}_{2}$, and outperform Z907, when using polyEDOT as an HTM (in situ polymerization of EDOT using photochemical or electrochemical methods). ${ }^{7}$ In this report they observed a titania thickness dependence on device performance, and suggested that the nature of the sensitizer could affect the effective penetration depth of the polymer HTM.

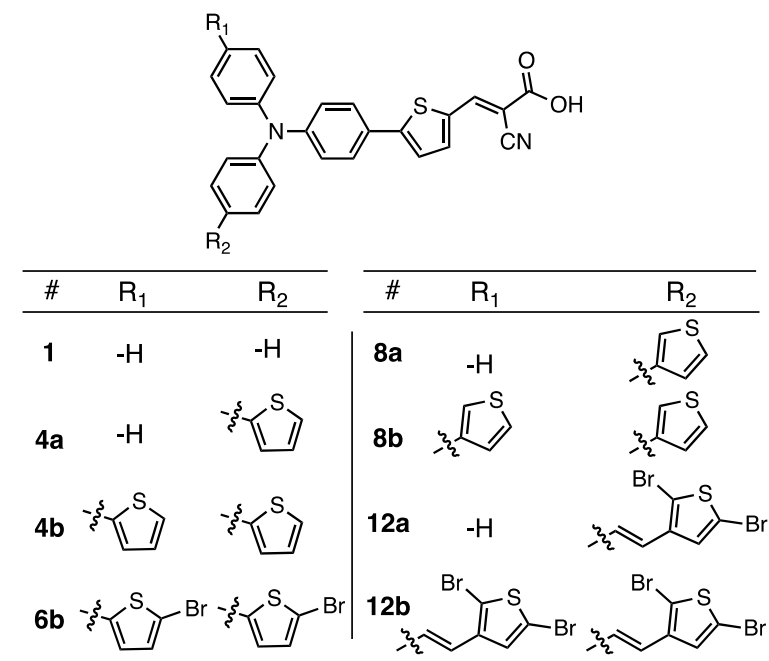

Figure 16 A Family of TPA dyes where the donor is substituted with various thienyl-subunits.

We wanted to systematically study this hypothesis and propose that if a donor, like the TPA in the previously reported $\mathbf{1}^{19}$ is equipped with polymerizable subunits, the resulting family of dyes may be able to integrate with the polymer film leading to increased pore filling, decreased dye-HTM interfacial capacitance, minimized recombination and improving long term stability. To this end, we have prepared a family of dyes based on 1 where the TPA donor is functionalized with pendant thiophene arms that are conjugated to donor. Before exploring these dyes in HTM-based devices, we 
have examined the effect of donor modification on the physicochemical properties and device performance with the traditional $\mathrm{I}^{2} / \mathrm{I}_{3}$ - electolyte. The results of this benchmark study are reported herein.

In order to examine the effect of TPA donor modification, we prepared a series of mono- and di-substituted thienyl derivatives (Figure 1). As depicted in Scheme 1 and Scheme 2, the TPA donor is particularly well suited for this modification, because it can be readily equipped with pendant thiophene substituents. In Scheme $1, \mathbf{2} \mathrm{a}^{20}$ and $\mathbf{2} \mathbf{b}^{21}$ serve as the starting points for Suzuki couplings with either 2- or 3-substituted thienyl boronic esters/acids. After Suzuki coupling and a Knoevenagel condensation with cyanoacetic acid, dyes families 4 and $\mathbf{8}$ were obtained in good yields (see Supporting Information). In the case of $\mathbf{6 b}$, bromination of $\mathbf{3 b}$ led to aldehyde $\mathbf{5}$ which smoothly underwent a Knoevenagel condensation with cyanoacetic acid, to make the desired di-substituted brominated TPA dye. Our impetus for brominating our dyes is to allow for postmodification and ideally facilitate polymerization with the HTM. Our current methodology precluded the possibility of preparing $\mathbf{6 a}$. The preparation of the conformationally more flexible family $\mathbf{1 2}$, used similar synthetic manipulations, but required a protection/deprotection methodology and the Horner-WadsworthEmmons reaction, to ensure a trans-substituted olefin (Scheme 2). 


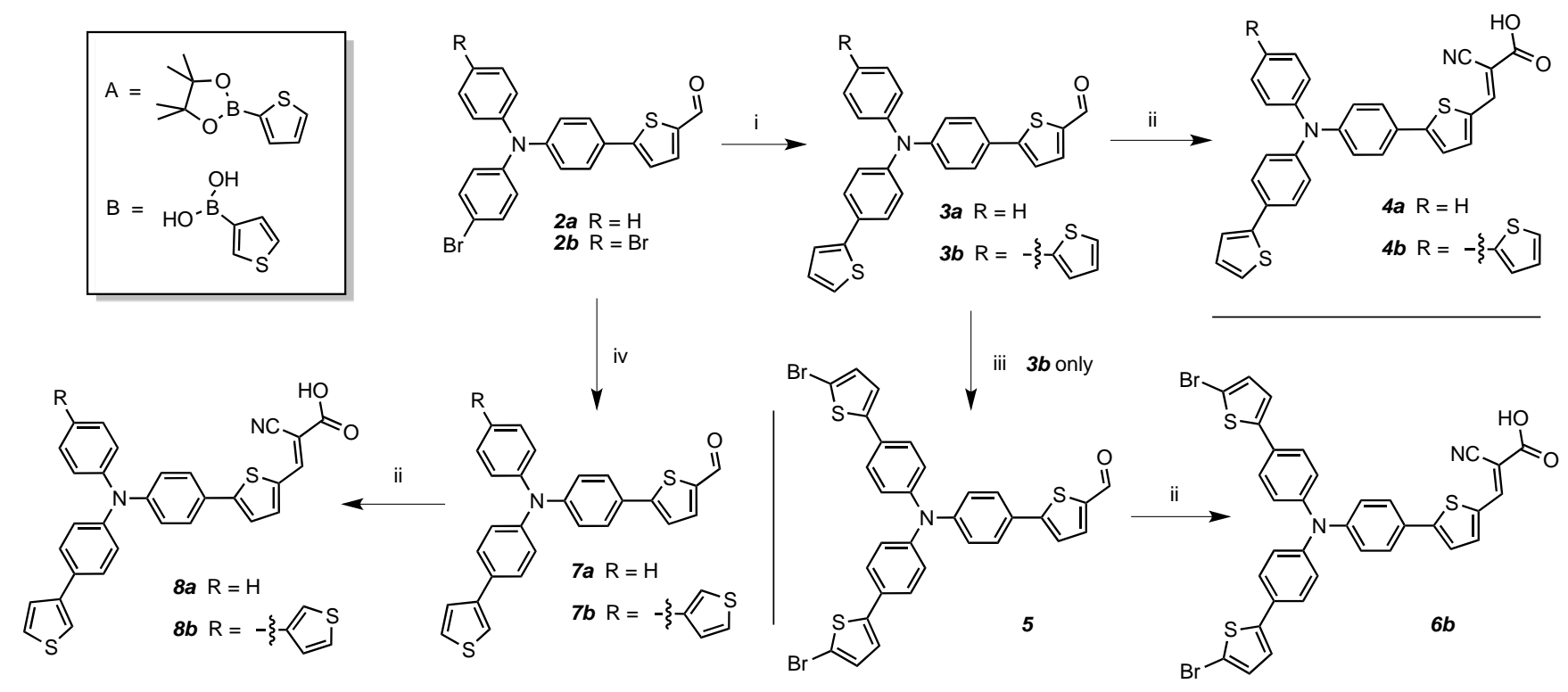

Scheme 1 Synthesis of Dyes Families $4 a, 4 b^{22}, 6 b, 8 a$ and $8 b$. Reaction Conditions: i) A (1.15 or 2.3 eq), $\mathrm{K}_{2} \mathrm{CO}_{3}\left(5\right.$ or 10 eq), $\mathrm{Pd}(\mathrm{PPh})_{4}$ (10 or 20\%mol), THF: $\mathrm{H}_{2} \mathrm{O} 9: 1$, reflux $12 \mathrm{~h}$ ii) cyanoacetic acid (2 eq), piperidine (0.25 eq), $\mathrm{CHCl}_{3}$, reflux $12 \mathrm{~h}$ iii) NBS (2.2 eq), THF:EtOAc 1:1, $25^{\circ} \mathrm{C}, 12 \mathrm{~h}$ iv) B (1.15 or $\left.2.3 \mathrm{eq}\right), \mathrm{K}_{2} \mathrm{CO}_{3}(5$ or $10 \mathrm{eq}), \mathrm{Pd}\left(\mathrm{PPh}_{3}\right)_{4}(10$ or $20 \% \mathrm{~mol}), \mathrm{THF}: \mathrm{H}_{2} \mathrm{O} 9: 1$, reflux $12 \mathrm{~h}$.

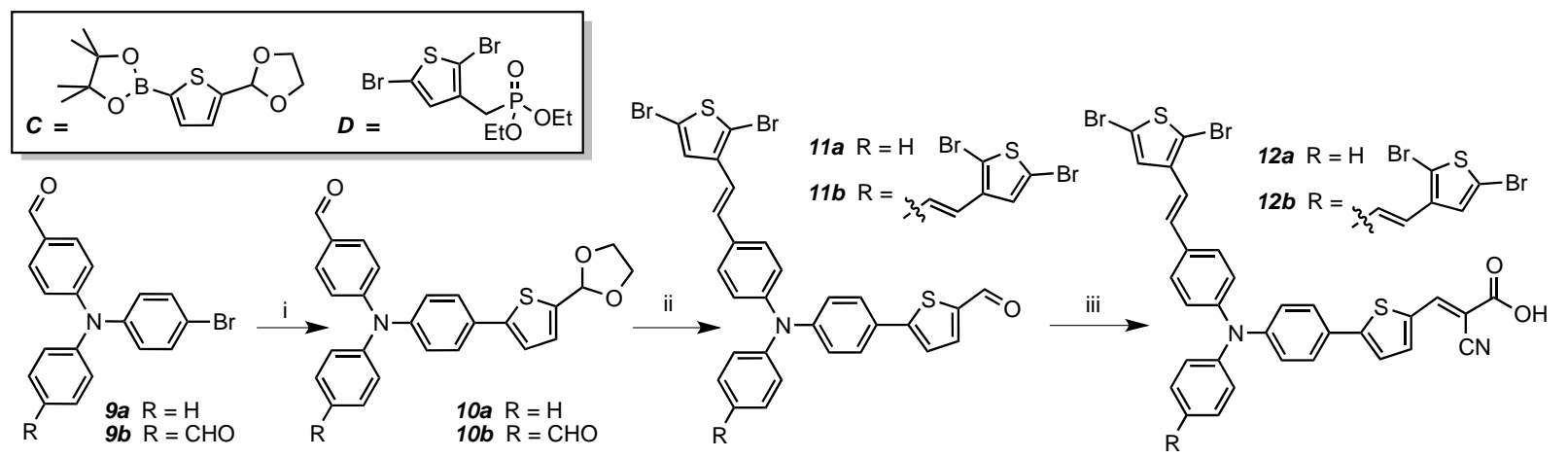

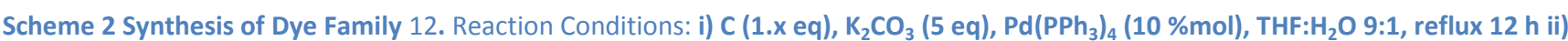
D (1.x or 2.x eq), tBuOK (1.x or 2.x eq), THF, reflux 24 h, glacial AcOH: $\mathrm{H}_{2} \mathrm{O} 2: 1$, reflux, $1 \mathrm{~h}$ iii) cyanoacetic acid (2 eq), piperidine (0.25 eq), $\mathrm{CHCl}_{3}$, reflux $12 \mathrm{~h}$.

Results and Discussion

Electrochemical data and UV-vis absorption data in DCM for the dyes and benchmark compound 1 has been presented in Table 1. All dyes exhibit a single reversible one electron oxidation. This is assigned as the HOMO energy, and is consistent with TPA oxidation. ${ }^{14}$ The TPA unit is sensitive to the donor modifications. Thienyl arms destabilize the HOMO, but the donating effect of substituted thiophenes varies according to the electron density arguments pertaining to thiophene 
rings. As can be observed in Table 1, a 2-substituted thiophene stabilizes the HOMO ( 30 mV) more than a 3-substituted thiophene ( 10 mV), owing to the higher electron density at the 2-position. The olefin substituted derivative, however, stabilizes the TPA HOMO owing to the increased s-character of the olefin substituent. Bromination stabilizes the HOMO (by $\sim 40 \mathrm{mV}$ ) when $\mathbf{6 b}$ is compared to the non-brominated $\mathbf{4 b}$, because of the electron withdrawing nature of the halide. Finally, disubstitution enhances all of the electronic trends discussed above.

\begin{tabular}{ccc} 
Compound & $\begin{array}{c}E_{1 / 2}(\mathrm{~V} \text { vs NHE })^{a} \\
\mathrm{TPA}^{*+} / \mathrm{TPA}\end{array}$ & $\begin{array}{c}\mathrm{UV}^{-\mathrm{vis}^{b}} \\
\lambda_{\max }, \mathrm{nm}\left(\varepsilon \times 10^{3}, \mathrm{M}^{-1} \mathrm{~cm}^{-1}\right)\end{array}$ \\
\hline $\mathbf{1}$ & 1.27 & $479(22.1), 346(12.3)$ \\
$\mathbf{4 a}$ & 1.24 & $487(37.4), 350(30.6)$ \\
$\mathbf{4 b}$ & 1.21 & $492(37.3), 360(45.6)$ \\
$\mathbf{6 b}$ & 1.25 & $489(39.3), 369(54.2)$ \\
$\mathbf{8 a}$ & 1.26 & $487(32.3), 329(25.6)$ \\
$\mathbf{8 b}$ & 1.23 & $492(33.9), 340(37.6)$ \\
$\mathbf{1 2 a}$ & 1.29 & $486(36.8), 371(38.8)$ \\
$\mathbf{1 2 b}$ & 1.32 & $491(33.9), 389(53.8)$
\end{tabular}

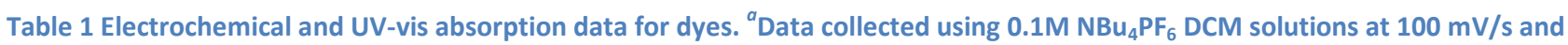
referenced to a $[\mathrm{Fc}] /[\mathrm{Fc}]^{+}$internal standard followed by conversion to $\mathrm{NHE} ;[\mathrm{Fc}] /\left[\mathrm{Fc}^{+}\right]=+765 \mathrm{mV}$ vs $\mathrm{NHE}$ in DCM. ${ }^{a}$ Data collected in DCM solutions
}

For all dyes, with the exception of 1 , sweeps to higher potential ( $1.3 \mathrm{~V})$, beyond the reversible TPA oxidation, resulted in a pseudo reversible wave that grows in intensity with multiple scans. This observation suggests thiophene polymer formation at the electrode surface and is consistent with the formation of thiophene-TPA linkages. ${ }^{23}$ Examination of the working electrode surface (Supporting Information; Figure S1) after multiple scans, shows the formation of an insoluble red polymeric film, which further supports the notion that these dyes could be successfully integrated with an HTM during an in situ polymerization.

A representative set of UV-Vis spectra recorded in DCM for $\mathbf{4 b}, \mathbf{6 b}, \mathbf{8 b}$, and $\mathbf{1 2} \mathbf{b}$ are presented in Figure 18 and tabulated in Table 1 (UV-Vis profiles of dyes 1, 4a, 8a, and 12a can be found in Figure 
S2). The UV-Vis spectra of all dyes show two signifcant absorptions; one at high-energy and one at low energy centred $c a$. at $500 \mathrm{~nm}$. When compared to the benchmark dye 1, it was satisfyingly observed that modifying the TPA donor increased the extinction coefficients and moderately redshifted the low energy absorption envelope. The low energy absorption has been assigned as the HOMO-LUMO transition and DFT calculated (B3LYP/6-31G) frontier orbitals are presented in Figure 19. However, the most signicant differences due to modification of the TPA, are observed in the high energy transition which has been assigned as the HOMO-LUMO+1 transition.

The HOMO of these dyes is centred on the TPA, but delocalized over the entire molecule (Figure 19). As a result of an increased optical cross-section, larger extinction coefficients are observed. The LUMO is appropriately located on the cyanoacetic anchor in all cases. The LUMO+1 is primary localized on the polymerizable subunits. As the conjugation lengths between the TPA and thienyl-subunit are increased, a significant bathochromic shift is observed in the higher energy absorption. A similar trend is observed for the mono-substituted TPA derivatives (4a, 8a, and 12a); however, this high energy band is less intense in all mono-substituted derivatives.

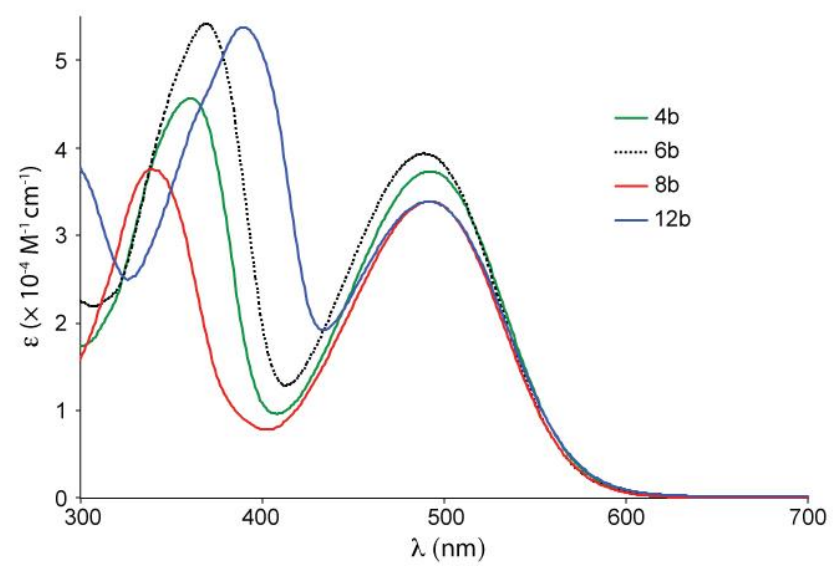

Figure 17 UV-vis spectra in DCM for the di-substituted TPA dyes 
With a detailed understanding of the physicochemical properties in solution, DSSC device performance was examined for our new family of dyes. The relevant parameters were extracted from the measured current-voltage traces under standard AM 1.5 sunlight and are detailed in Table 2 . We were satisfied to observe that each of our modified dyes had a higher device efficiency than the benchmark dye $\mathbf{1}$. The highest performing dyes were $\mathbf{4 b}$ and $\mathbf{8} \mathbf{b}$; but suprisingly, $\mathbf{1 2} \mathbf{b}$ had the lowest performance of this new family.

\begin{tabular}{ccccc} 
Compound & $J_{s c}\left(\mathrm{~mA} / \mathrm{cm}^{2}\right)$ & $V_{o c}(\mathrm{~V})$ & $F F$ & $\eta(\%)$ \\
\hline $\mathbf{1}$ & 10.93 & 0.68 & 0.70 & 5.15 \\
$\mathbf{4 a}$ & 11.65 & 0.70 & 0.72 & 5.84 \\
$\mathbf{4 b}$ & 12.59 & 0.71 & 0.73 & 6.48 \\
$\mathbf{6 b}$ & 12.12 & 0.71 & 0.72 & 6.23 \\
$\mathbf{8 a}$ & 11.90 & 0.69 & 0.71 & 5.89 \\
$\mathbf{8 b}$ & 12.86 & 0.71 & 0.72 & 6.56 \\
$\mathbf{1 2 a}$ & 10.80 & 0.70 & 0.74 & 5.59 \\
$\mathbf{1 2 b}$ & 11.33 & 0.68 & 0.72 & 5.51
\end{tabular}

Table 2 Solar Cell Performance Parameters Obtained Under Simulated AM 1.5 Illumination for Select Dyes. ${ }^{a}$ Device fabrication and data collection procedures can be found in the Supporting Information.

Several structure property relationships can be observed in this series. The first is that disubstituted TPAs outperform mono-substituted derivative owing to increased light harvesting (see Table 1). Furthermore within the error of the measurement, there is no significant different between 2- and 3substituted thiophenes. $\mathbf{1 2 a}$ and $\mathbf{1 2} \mathbf{b}$, with the olefin spacer, were designed to offer conformational flexibility for future in situ polymerizations; therefore, it was a little dissapointing to see this dye with the lowest performance. While differing dye-electrolyte interactions can not be ruled out, all dyes were studied using the same $\mathbf{Z 1 1 3 7} \mathrm{I}^{-} / \mathrm{I}_{3}{ }^{-}$electrolyte and it is reasonable to assume that because these dyes have similar hydrophobicity, owing to their similar polyaromatic structure, regeneration mechanisms would not be rate limiting. Furthermore, assuming we are operating within a normal Markus region, regeneration for $\mathbf{1 2 b}$ should be fastest because it has the most stabilized HOMO. 
Heavy atom quenching (by the bromine atoms) of the excited state can also be ruled out because the same poor performance was not observed in $\mathbf{6 b}$.

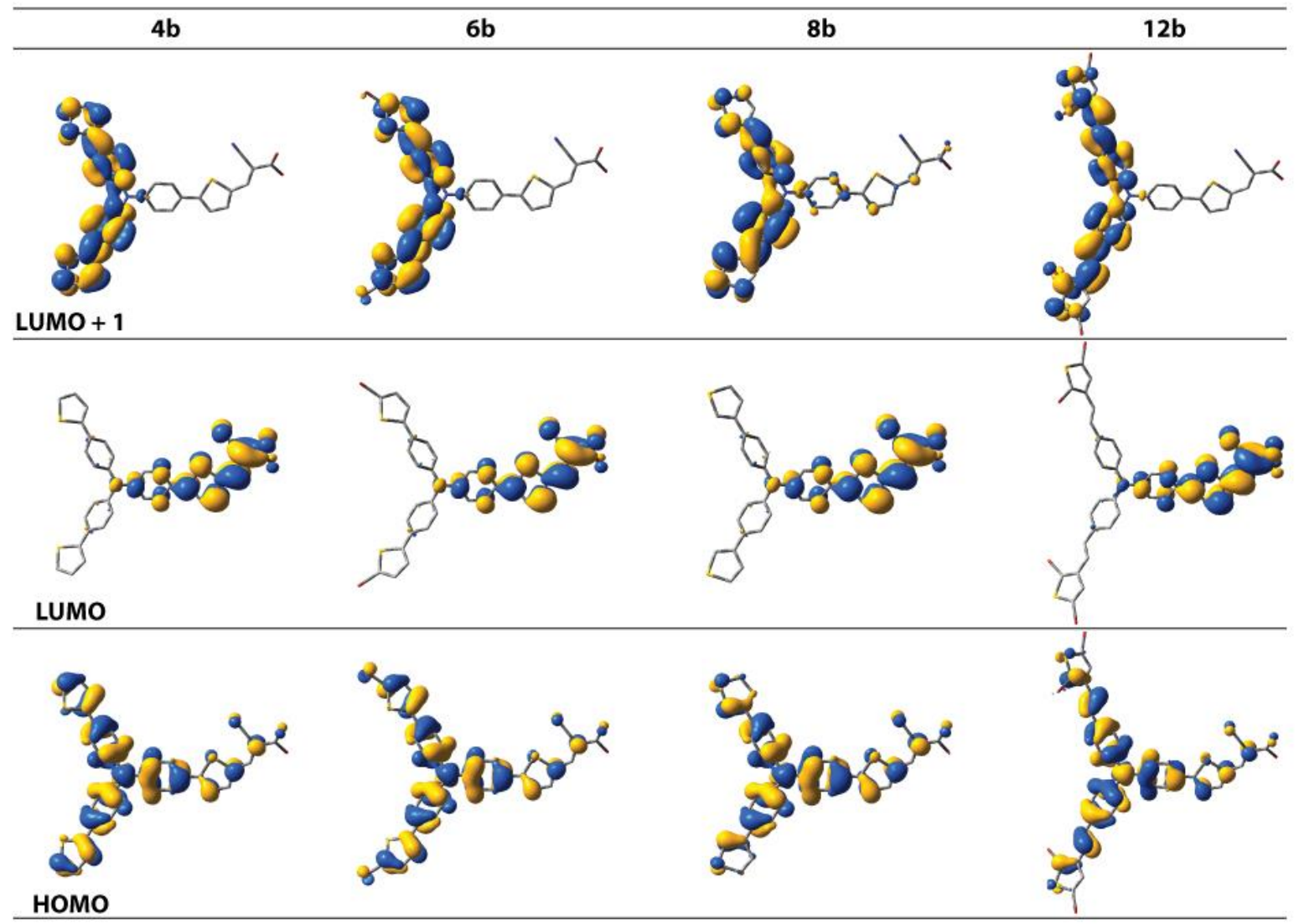

Figure 18 Frontier molecular orbitals as predicted by DFT (B3LYP/6-31G) for di-substituted dyes 4b, 6b, 8b, $12 b$.

The incident photon-to-electricity conversion efficiency (IPCE) spectrum for disubstitued dyes is presented in Figure 20. Despite having a similar profile to $\mathbf{4 b}$ and $\mathbf{8 b}$, the current response for $\mathbf{1 2 b}$ is $\sim 10 \%$ lower for most of the visible spectrum. 


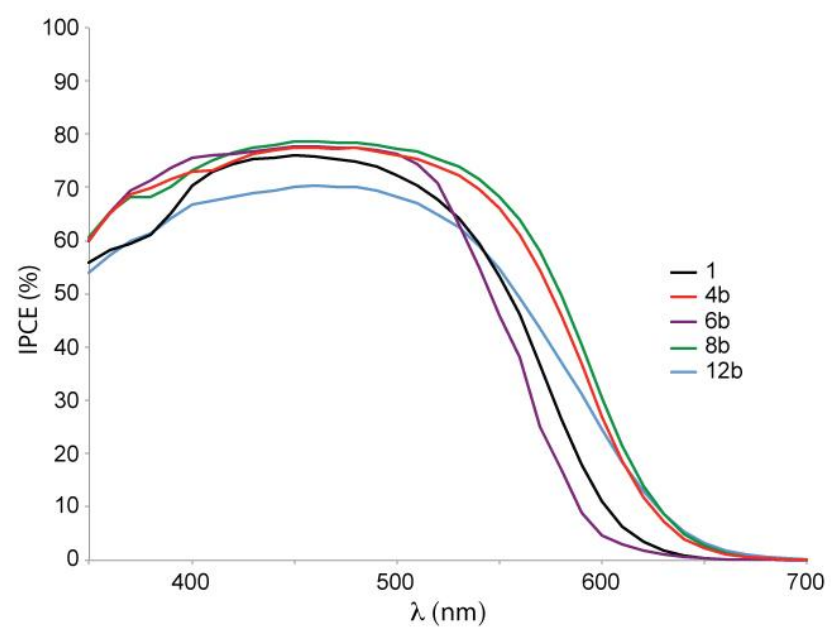

Figure 19 Photocurrent action spectrum obtained for di-substituted dyes attached to $\mathrm{TiO}_{2}$ films using the Z1137 electrolyte.

When considering the hydrodynamic volume of $\mathbf{1 2 b}$, the most rationale explanation for the low $\mathrm{J}_{\mathrm{sc}}$ and $\mathrm{V}_{\mathrm{oc}}$ (and ultimately performance) is reduced dye loading on the $\mathrm{TiO}_{2}$ surface. Unfortunately, the preprogrammed conformational flexibility. meant to facilitate integration with the HTM would also prohibit dye loading, once again reaffirming the classical organic reasoning that both electronics and sterics are important considerations in molecular design.

Conclusions

To gain a fundamental understanding of how donor modification can affect the physicochemical properties and device performance we have prepared a family of TPA dyes equipped with thienyl subunits. All dyes outperformed the benchmark dye 1 in device measurments owing to their improved photocurrents. These dyes show excellent promise for integration into polythiophene-based HTMs and we have demonstrated that the level of covalent bonding with the HTM could be varied through TPA modification (either mono- or di-substitution). This intimate connection with the HTM should facilitate hole-transport away from the dye rapidly stabilizing the photo-oxidized dye. Now that the $\mathrm{I}^{-} / \mathrm{l}_{3}^{-}$electrolyte benchmark has been established we are poised to 
examine these dyes with HTM-based electrolytes. Studies are underway to examine the performance of these dyes in HTM-DSSC architectures and these results will be disseminated in a future report. 


\section{Chapter 3: Synthesis and study of bichromic triphenylamine-based dyes furnished}

with bipodal features for light-harvesting applications

\section{1: Intent of the work}

This manuscript presents a different route towards investigation of triphenylamine based dyes; instead of improving the dye/electrolyte interface, dye systems which can increase the durability of the device through improvement of the dye/titania interfacial layer are studied. A multichromic and bipodal dye system is designed by utilizing the triphenylamine moiety as an extra donor to increase the absorption envelope and an extra anchor to stabilize the dye on the substrate surface.

\section{2: Significant Outcomes}

The multichromic and bipodal dye systems showed interesting light-harvesting abilities and have shown tunable redox stability. The use an extra anchoring moiety also appears to have a significant effect on the shape of the absorption profile.

\section{3: Contributions by the authors}

I conducted the majority of the synthesis with the assistance of Hardeep S. Devgan in synthesizing building block materials. The physicochemical characterizations were performed by the author. DFT and TD-DFT calculations were performed by Dr. Eduardo S. Schott.

\section{4: Manuscript}

A family of four triphenylamine-based dyes, three of which incorporate multiple triphenylamine donor units, have been studied to understand their potential in light-harvesting materials applications. An improved absorption envelope is reported herein due to the use of an additional redox-active chromophore unit. 
Organic light-harvesting dyes are undergoing a renaissance in the current literature owing to their facile synthesis, tunability and high extinction coefficients when applied to light-harvesting applications. ${ }^{32,44,45,46}$ Organic chromophores driven by intense $\pi-\pi^{*}$ absorption bands tend to have sharp absorptions with minimal effective charge redistribution unless they are outfitted with donor (D) and acceptor (A) units. Incorporation of a D- $\pi-A$ motif, however, facilitates the formation of an exciton at lower energy and allows for significant intramolecular charge transfer, necessary for charge extraction. ${ }^{47,48,49}$ While the catalogue of donors, $\pi$-spacers and acceptor groups is large, upon charge extraction, the redox stability of the organic dye is also an important consideration. To this end, redox robust triphenylamine (TPA) have become ubiquitous as building blocks in light-harvesting scaffolds, particularly in the literature relating to dye-sensitised solar cell (DSSC) applications. ${ }^{50,8,51,52,53}$

In the design of DSSC dyes, the HOMO orbital must lie predominantly on the donor (TPA) end and the LUMO should be localized on the acceptor to allow for proper injection into the conduction band of the semiconductor. Additionally, intermolecular dye interactions can lead to unfavourable surface aggregation and quenching which are significant issues in material applications, so candidate donors must be structured in a way to prevent $\pi$-stacking. As a result, triphenylamine based donors are optimal candidates as donors in the DSSC owing to their electron rich nature, redox stability and nonplanarity. Since the benchmark reports of TPA as a donor in DSSC applications, ${ }^{54,55,56,56}$ two champion (> 10\% efficiency) organic dyes have emerged with this donor motif. ${ }^{57,58}$ However, to realize further improvements in organic dyes for DSSC applications, three significant challenges must still be addressed. 1)increased panchromatic absorption into the near-IR; 2) improved redox stability and dye lifetime; and 3) improved electronic communication between interfaces. To confront the issue of panchromatic absorption, researchers have studied cosensitisation with sensitizers that have 
complementary absorption envelopes. ${ }^{59,43}$ Cosensitisation assumes improvements in the absorption profile will be able to compensate for attenuated dye concentration; however, this is not often realised.

Continuing our work on modified triphenylamine donors ${ }^{27}$ and bichromic dye motifs ${ }^{34,60}$ for DSSC applications, we propose the following bipodal dye family (OA1, OA2, OA3; Figure 21) with multiple TPA units. While our previous work has investigated improvements at the dye/electrolyte interface, ${ }^{27}$ the bipodal (two cyanoacetic acid anchors) motif has been included to address stability and electronic communication at the semiconductor/dye interface. In addition, incorporation of multiple redoxactive TPA units seeks to address panchromatic absorption, charge separation and redox robustness within the organic dye motif. While multi-donor triarylamine systems have been studied previously, ${ }^{61,62}$ these systems typically have large hydrodynamic volumes that can lead to decreased dye loading, and ultimately lower device efficiencies.

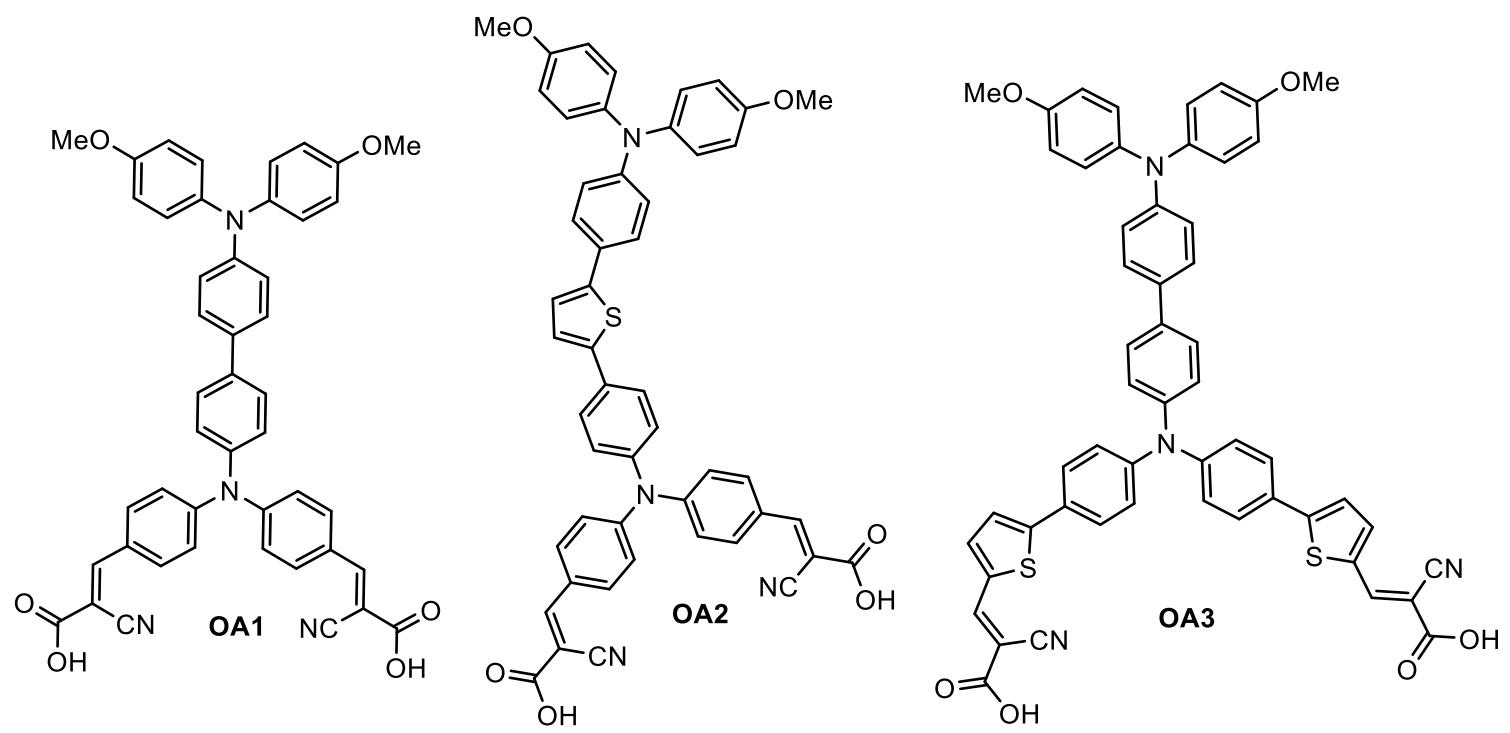

Figure 20 Bichromic Dyes: OA1, OA2 and OA3. A synthetic scheme is presented in the supporting information. 
The set of dyes OA1, OA2 and OA3 differ in the positioning of the thiophene-bridge or lack thereof (OA1). The intent of this adjustment is to examine the electronic communication between the anchor and donors, or the donors themselves. To compare the effectiveness of multiple triphenylamine donor units on the molecular absorption envelope and redox behaviour, we have also prepared a monochromic TPA dye OA4 and L1 as benchmark compounds. Herein, we present the physicochemical behaviour of this novel family of bichromic and bipodal dyes.

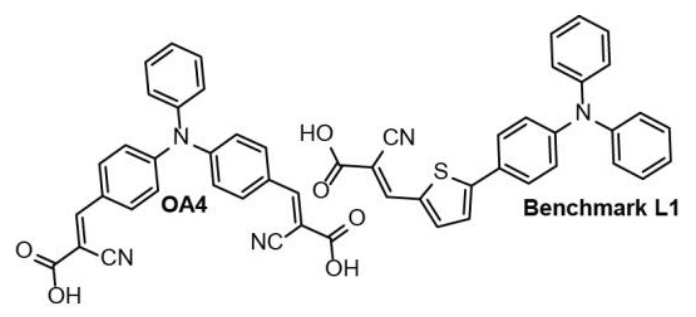

Figure 21 Dye OA4 and previously reported benchmark dye L1. Synthetic scheme for OA4 is presented in the supporting information.

To systematically appreciate the behaviour of these multiple redox active dyes, the physicochemical properties of the precursor compounds were investigated. The electrochemical and absorption data, collected in DCM solutions, has been collated and presented in Table 3, and the UVVis data presented in Figure 23. As mentioned previously, TPA donors show reversible oxidation potentials that can be tuned by appending various electron withdrawing and donating groups. As expected, the addition of a second electron withdrawing aldehyde to formyITPA manifests in a higher oxidation potential and bathochromic absorption. 


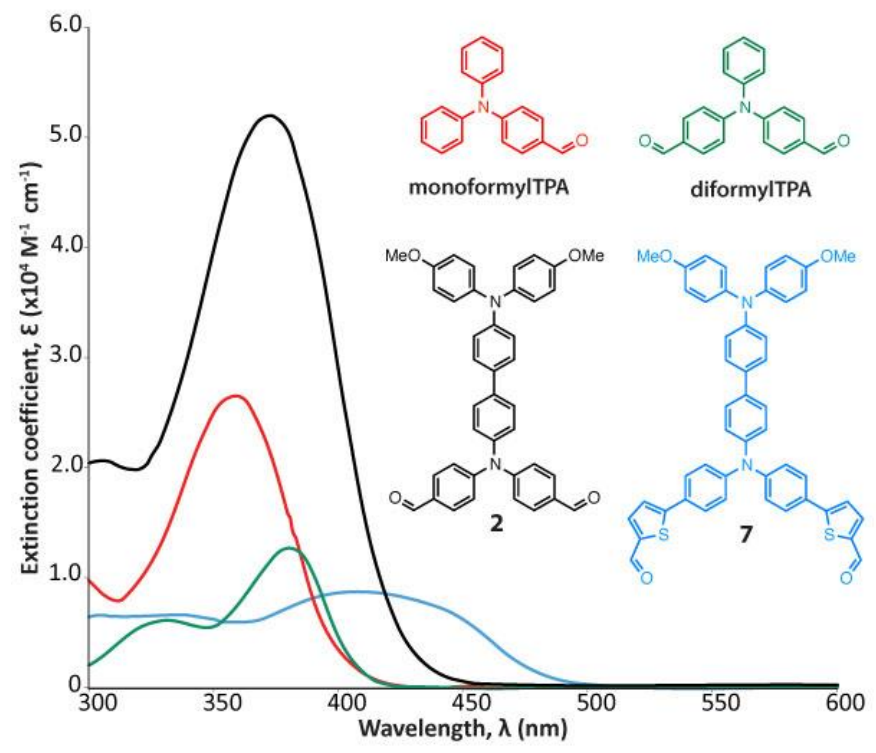

Figure 22 UV-Vis spectra of aldehyde precursors in DCM.

When this diformyl species is coupled to the electron rich bisOMeTPA unit there is a significant stabilization observed in the first oxidation, and a second reversible oxidative process emerges in molecule 2. Despite the observance of distinct oxidations, the reversible waves cannot be assigned to a single TPA unit but rather that of the whole system. The DFT calculated molecular orbitals for the HOMO, show electron density localized primarily on the bisOMeTPA unit and the LUMO residing predominantly on the aldehyde portion of the molecule. There is also a hypsochromic shift in the absorption profile, which is attributed to a significant increase in the LUMO orbital energy, and a more significant contribution from the HOMO-LUMO+1 transition. The inclusion of a thiophene spacer between the electron withdrawing aldehyde and TPA unit in derivative 7, has yet another more significant effect on the absorption profile. In this derivative, there is a significant destabilization of the second oxidation process and the presence of a low energy absorption tail extending out to $500 \mathrm{~nm}$. Additionally, there is a substantial decrease in the extinction coefficient. Based on DFT calculations, the inclusion of the thiophene unit increases electron density on the 
proximal TPA unit, and the oscillator strength of all transitions is substantially diminished likely owing to the weaker electronic dipole found in the molecule.

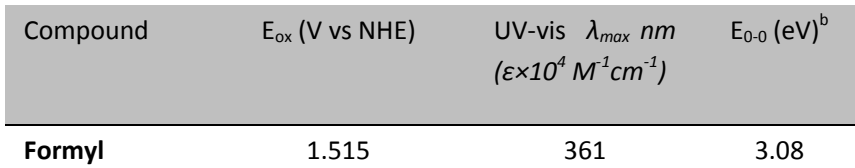

TPA

(2.6)

TPA

2

0.983

1.441

7

0.958

1.285
(0.6) (1.3)

374

2.92

(5.2)

404

2.56

(0.9)

Table 3 Physicochemical characterization of aldehyde precursors. ${ }^{a}$ Data collected using $0.1 \mathrm{M} \mathrm{NBu}_{4} \mathrm{PF}_{6} \mathrm{DCM}$ solutions at $100 \mathrm{mVs}{ }^{-1}$ and referenced to a $[\mathrm{Fc}] /[\mathrm{Fc}]+$ internal standard followed by conversion to $\mathrm{NHE} ;[\mathrm{Fc}] /[\mathrm{Fc}+]=+765 \mathrm{mV}$ vs. $\mathrm{NHE}$ in $\mathrm{DCM} ;{ }^{\mathrm{b}} \mathrm{E}_{0-0}$ calculated from $10 \%$ of the absorption maxima. Further details for Table 2 derivatives can be found in the supporting information

To investigate the frontier energy levels of the dye family the electrochemical and absorption data, collected in DCM solutions, has been collated and presented in Table 2, and the UV-Vis data presented in Figure 24. In all cases, owing to the presence of two redox-active TPA units (with the exception of monoTPA dye OA4) the dyes exhibit two reversible oxidations, akin to precursors 2 and 7. 


\begin{tabular}{|c|c|c|c|c|}
\hline Compound & $\mathrm{E}_{\text {ox }}(\mathrm{V} \text { vs NHE })^{\mathrm{a}}$ & $\begin{array}{l}\text { UV-vis } \\
\left(\varepsilon \times 10^{4}\right.\end{array}$ & $\begin{array}{l}\lambda_{\max } n m \\
\left.n^{-1} \mathrm{~cm}^{-1}\right)\end{array}$ & $E_{0-0}(e V)^{b}$ \\
\hline OA1 & $\begin{array}{l}0.99 \\
1.47\end{array}$ & $\begin{array}{l}471 \\
(3.4)\end{array}$ & $\begin{array}{l}417 \\
(2.8)\end{array}$ & 2.33 \\
\hline OA2 & $\begin{array}{l}1.04 \\
1.39\end{array}$ & & 8) & 2.45 \\
\hline OA3 & $\begin{array}{l}0.95 \\
1.26\end{array}$ & $\begin{array}{c}497 \\
(0.50)\end{array}$ & $\begin{array}{c}357 \\
(0.57)\end{array}$ & 2.05 \\
\hline OA4 & 1.53 & $\begin{array}{l}461 \\
(2.6)\end{array}$ & $\begin{array}{l}394 \\
(1.1)\end{array}$ & 2.44 \\
\hline L1 & 1.30 & $\begin{array}{l}483 \\
(3.2)\end{array}$ & $\begin{array}{c}344 \\
(1.9)\end{array}$ & 2.23 \\
\hline
\end{tabular}

Table 4 . Physicochemical characterization of $\mathrm{L} 1, \mathrm{OA} 1, \mathrm{OA} 2, \mathrm{OA} 3$ and $\mathrm{OA} 4 .{ }^{a}$ Data collected using $0.1 \mathrm{M} \mathrm{NBu}_{4} \mathrm{PF}_{6} \mathrm{DCM}_{\text {solutions at } 100}$ $\mathrm{mVs}^{-1}$ and referenced to $\mathrm{a}[\mathrm{Fc}] /[\mathrm{Fc}]+$ internal standard followed by conversion to $\mathrm{NHE} ;[\mathrm{Fc}] /[\mathrm{Fc}+]=+765 \mathrm{mV}$ vs. $\mathrm{NHE}$ in $\mathrm{DCM}$; ${ }^{\mathrm{b}} \mathrm{E}_{0-0}$ calculated from $10 \%$ of the absorption maxima

The trends across the family are consistent with the behaviour observed in the model compounds, and rationalized in part using DFT and TD-DFT (see supporting information, Figure S2). Considering benchmark bipod OA4, a single oxidation is observed owing to the presence of only one redox active TPA unit. When comparing the electrochemical behaviour of OA4 to the diformyITPA precursor, there is only a modest change in the oxidation potential implying that the electron withdrawing effect of an aldehyde and cyanoacetic acid groups are comparable. The optical behaviour of precursor and OA4 is also similar, but significantly red-shifted in the dye, likely due to the extended conjugation found in the dye.

Consistent with bisTPA precursors (Table 3), combining the motif found in OA4 with the electron rich bisOMeTPA results in a new reversible oxidation appearing at a significantly lower potential in OA1. Based on DFT calculations, this is attributed to the HOMO orbital for all bichromic dyes residing on the bisOMeTPA unit, and depending on the location of the thiophene unit, this oxidation potential 
can shift approximately $50 \mathrm{mV}$. For example in $\mathbf{O A 2}$, the presence of the thiophene spacer between the TPA units further stabilizes the HOMO owing to improved conjugation with the more electron deficient TPA unit. In OA3, the facile electronic communication between TPAs no longer exists, and this HOMO stabilization is no longer observed. These trends do not hold in the second oxidation process in this family, owing to the stability of the products. While it is fairly straightforward to draw trends with the first oxidation potential, the second oxidation potential is more heavily influenced by the reorganizational energy leading to the product (likely quinoidal in nature), and both the rates and free energy of electron transfer may cross into the inverted Markus region.

Looking at the absorption profile (Figure 24) for OA4 refutes the notion that the addition of another donor unit is necessary to create a bichromic absorption profile. OA4 has two absorption bands when compared to the benchmark L1, which suggests that "bichromicity" being imparted maybe due to the addition of another acceptor unit and not the donor unit. Regardless, a broader absorption envelope is observed for all bisTPA dyes when compared to OA4, likely due to the generation of destabilized HOMO orbitals. Like OA4, OA1 exhibits two well-resolved maxima with increasing energy, assigned as the HOMO-1 to LUMO \& HOMO to LUMO+2, respectively.

While OA2 has approximately the same cross-section as other dyes, it exhibits a much higher extinction coefficient. TD-DFT calculations predict that owing to the significant electronic communication between the TPA units, a new dominant transition emerges from the HOMO-1 to LUMO+1. This transition is closer in energy to the HOMO-LUMO+1 transition and as a result coalescence of the bichromic absorptions occurs resulting in a hypsochromic shift in the absorption maxima and an apparent increase in extinction coefficient. 
The low extinction coefficient for $\mathbf{O A 3}$ is consistent with the aldehyde precursor and is again attributed to the hindered polarizability owing to the spatial distance between donor and acceptor and the lack of electronic communication between the TPA moieties. Furthermore, while the HOMO1 to LUMO \& HOMO-2 to LUMO+1 dominate in OA3, unlike other dyes in the family there is a significant increase in the HOMO-LUMO oscillator strength, which explains the red-shifted absorption tail.

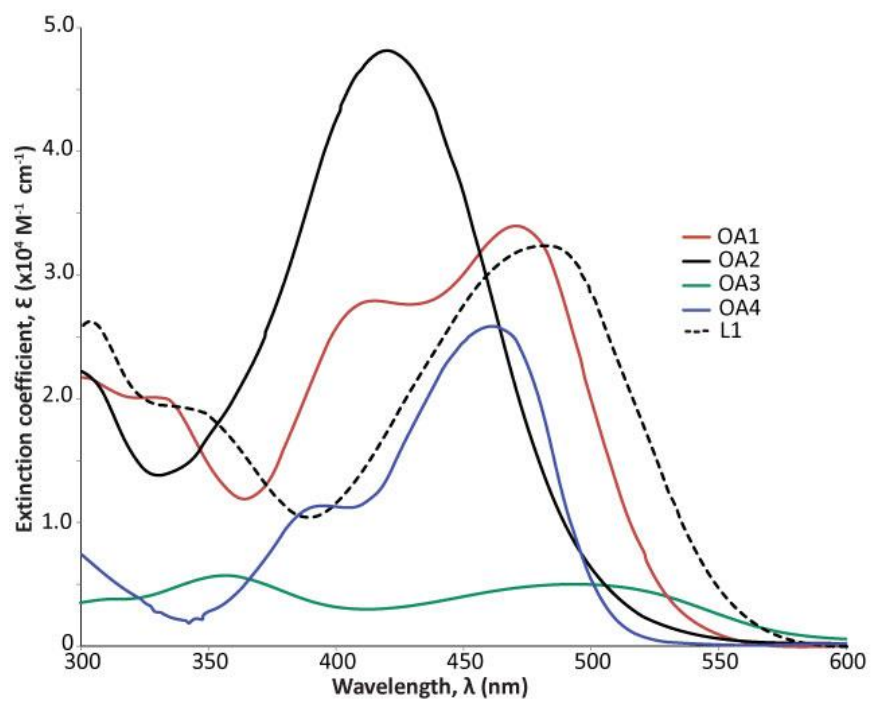

Figure 23 UV-Vis Spectrum of dyes OA1, OA2, OA3, OA4 and benchmark L1 in DCM.

When considering the utility of these dyes for DSSC applications, the HOMO orbital resides at a favorable energy when considering the common electrolytes and regeneration dynamics. Owing to the lack of information regarding the energy of the LUMO orbitals, it is difficult to determine if there would be a significant thermodynamic driving force for injection into the semiconductor conduction band, but each of these dyes do have LUMO orbitals situated substantially on the acceptor units, and therefore injection may be kinetically favorable. When compared to benchmark L1, the blueshifted or weaker absorption profiles of OA1, OA2 and OA3 may hinder device performance, but it is expected that having multiple redox active centres may increase the redox robustness of the material. 


\section{Conclusions}

A set of bipodal multichromic dyes, OA1, OA2 and OA3 have been synthesized and studied. In the absence of device data, these dyes not only show promise as light-harvesting agents but they also elucidate how future molecular systems can be engineered to achieve panchromaticity. An improved absorption envelope has been demonstrated when an additional donor moiety is attached to a dye system when compared to benchmark OA4. While these dyes appear suitable for DSSC applications the next challenge will be device fabrication and optimization. In addition to efficiency, device studies will investigate redox stability and dye binding to the semiconductor surface, to determine if our bipodal/bichromic features are desirable for organic dye design. 


\section{Chapter 4: Summary, Conclusions and Future work}

Two objectives have been met in this project. The design of family of dyes which have an improved absorption profile vs corresponding mono-donor systems; it can be hypothesized that the $\mathrm{J}_{\mathrm{sc}}$ should improve owing to the improved light-harvesting abilities imbued by the extra TPA donor as well, due to the reduced impedance owing to the lack of a barrier between the dye and the HTM. The stability of the device should see an improvement by future empirical studies of the dye loading on the titania surface.

Two distinct dye families have been created that exemplify the high-performing characteristics of the TPA donor and its flexible tunability. They show decent light-harvesting capabilities. In the first manuscript device data was obtained and the dye family showed relatively high efficiencies, even, outperforming the benchmark dye. A family of candidate multichromic and bipodal dyes for device fabrication have been investigated. Functionalization of a sensitizer with an additional donor unit had the property of improving the intensity of light absorption and increasing the absorption envelope. Due to their potential as excellent light-harvesting agents, they have been applied in DSSCs to determine their suitability towards further functionalization with pendant thiophene arms to pair it with the HTM project to design a fully solid-state device. Device data has been retrieved for the multichromic and bipodal series of dyes and their benchmarks. Discouraging efficiencies have been obtained due to inexperience with device fabrication (Figure 24) as well as the high electrode resistances (30-60 $\Omega$ ). Solvents utilized in dye loading also plays an important role in the efficiencies as well. The dye bath was made up of a DMF solvent and this has been shown to lead

to poor device efficiencies due to poor dye loading. ${ }^{63}$ It is encouraging that the benchmark was outperformed but further optimization of the device fabrication process is needed before conclusions can be made. 


\begin{tabular}{|c|c|c|c|c|c|}
\hline Dyes & Voc $(\mathbf{V})$ & Jsc $\left(\mathrm{A} / \mathrm{cm}^{2}\right)$ & $\begin{array}{c}\text { Pmax } \\
\left(\mathbf{W} / \mathrm{cm}^{2}\right)\end{array}$ & FF & efficiency \% \\
\hline OA1 & 0.481 & $8.97 \mathrm{E}-04$ & $1.72 \mathrm{E}-04$ & 0.397 & 1.00 \\
\hline OA2 & 0.458 & $7.08 \mathrm{E}-04$ & $1.51 \mathrm{E}-04$ & 0.466 & 1.00 \\
\hline OA3 & 0.444 & $3.36 \mathrm{E}-04$ & $7.70 \mathrm{E}-05$ & 0.52 & 1.01 \\
\hline OA4 & 0.306 & $1.05 \mathrm{E}-04$ & $1.96 \mathrm{E}-05$ & 0.609 & 1.00 \\
\hline L1 & 0.405 & $1.05 \mathrm{E}-04$ & $1.86 \mathrm{E}-04$ & 0.436 & 0.10 \\
\hline
\end{tabular}

Table 5 Device efficiency metrics.<smiles>N#C/C(=C\c1ccc(N(c2ccc(/C(C#N)=C(\O)C(=O)O)cc2)c2ccc(-c3ccc(N(c4ccc(-c5ccsc5)cc4)c4ccc(-c5ccsc5)cc4)cc3)cc2)cc1)C(=O)O</smiles>

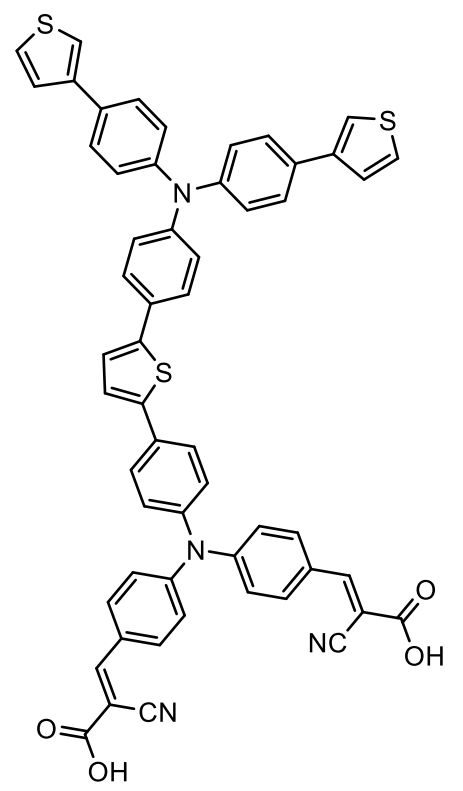<smiles>N#C/C(=C\c1ccc(-c2ccc(N(c3ccc(-c4ccc(N(c5ccc(-c6ccsc6)cc5)c5ccc(-c6ccsc6)cc5)cc4)cc3)c3ccc(-c4ccc(C=C(C(=O)O)C(=O)O)s4)cc3)cc2)s1)C(=O)O</smiles>

Figure 24 Candidate dyes for direct integration into a Hole-transport material. 


\section{1: Towards printable DSSC dyes}

Next generation photovoltaics are heading in the direction of being fabricated as thin-film solid state devices. Bulk heterojunction cells and dye-sensitized solar cells (DSSC) are two low cost photovoltaic devices that can be manufactured as thin films. This chapter will explore how $3 \mathrm{~d}$ printing technology could lead to novel and cost-effective ways of fabricating DSSCs. To explore $3 \mathrm{~d}$ printing of DSSCs as a proof of concept, all of the components must be incorporated as an ink formulation of some kind that can be extruded or printed with a simple inkjet printer. This presents itself as a challenge because intuitively it is difficult to conceptualize semiconducting oxides like FTO and $\mathrm{TiO}_{2}$ as extrudable or printable material. Considerable advances have been made in the literature with regards to ink formulations of metal oxides as colloidal and solgel inks as these two types are the most common methods of producing metal oxide ink formulations; dye ink formulations can be made as a regular solution.

Colloidal inks are ink formulations that are dispersions of nanoparticulates in moderately high boiling solvents such as: water, ethylene glycol, toluene and cyclohexanone. ${ }^{64}$ The required size of the nanoparticle dispersions is a parameter determined by the inkjet nozzle size. The films deposited by these inks still require processing even after solvent evaporation. This is for two reasons: to remove the surfactants originally used, and if a metal or oxide dispersion was created, to provide a proper conductive film morphology. ${ }^{65}$ Surfactants can disrupt the performance of printed thin films; the crude film can be treated to a high temperature or exposed to UV light. ${ }^{65}$ The use of capping agents that can easily cleave photocatalytically are becoming popular to reduce post-processing temperatures. 


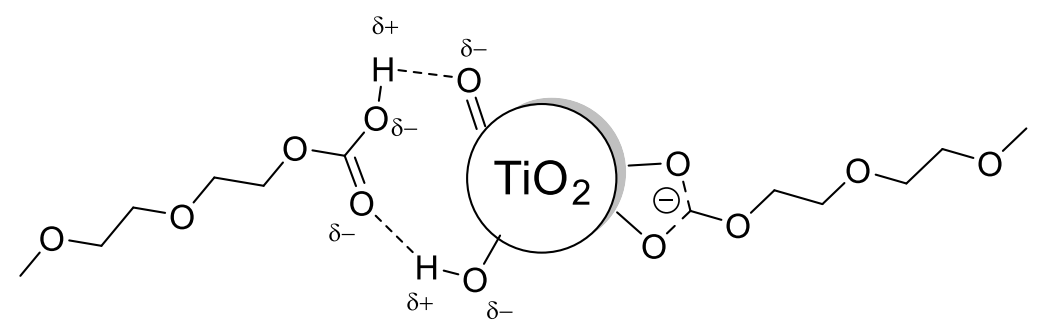

Figure 25 Surfactants are often deprotonated to promote stronger binding onto a colloidal particle (right-most surfactant). For surfactants that need to be removed easily, they can be left in their acidic form and bond through a hydrogen bonding motif (left surfactant).

The sol-gel process was developed as a low temperature glass making technique almost 200 years ago. ${ }^{66}$ The sol-gel is a binary network of liquid and solid phases that take on a gel-like constitution. The common method of synthesizing sol-gels, especially for additive manufacturing (or 3d-printing), is the hydrolysis and polycondensation of alkoxides. ${ }^{66,67}$ They are prominently used for the development of thin film oxides. ${ }^{66,67}$ However, they are also attractive for the design of ordered 3dimensional micro-and nano-structures. Due to their tunable viscosity, sol-gel inks have ability to be directly written on substrates as a filament or deposited as droplets with inkjet nozzles (provided the viscosity is low enough). Despite their advantages the high temperatures required to process sol-gel ink formulations make them disadvantageous to fabricate DSSCs.

Substrates are an important topic of discussion for 3d-printing, especially when using inkjet printing techniques. The printing of a device requires a base as foundation; this foundation prevents environmental contamination or prevents reactions with the outside world. This is analogous to the use of a chassis for any of the electrical instruments or machines that are produced. The substrate should also provide useful mechanical or optical properties beneficial to the operation of 3-D printed thin film devices: flexibility or transparency. Flexibility provides portability, cost-effectiveness and a thin profile for PV devices. ${ }^{68}$ Transparency is a required property for PV devices. 
Glass substrates are useful for a variety of thin film applications from transistors, display, photodetector and photovoltaic technology. ${ }^{68,69,70,71}$ Glass as an optical material is already prevailing due to their high optical transmittance even as thick sheets. Glass is inherently brittle, so in order to obtain flexibility, substrates are made to be extremely thin from $0.22 \mathrm{~mm}$ to 30 um. $^{56}$ Optimal flexibility was found to begin at a thickness of approximately 200 um. ${ }^{63}$ Bending radii are competitive with plastic substrates, as low as $12 \mathrm{~mm}^{57}$, can be obtained; the lower the bending radius (greater curvature), the better the flexibility. Glass is advantageous over substrates consisting of paper and plastic due to their high operating temperatures that are required to deform or melt. They are also chemically unreactive to a degree and impermeable to moisture and air. Wetting of glass substrates for a variety of organic and aqueous liquids is great: highest contact angles experimentally observed are $33^{\circ} .72$

Paper is not a conventional substrate for thin film devices and seems like an unusual candidate; but their environmentally benign nature and recyclability offers competitive leverage over plastic and glass substrates. Inkjet technology is already optimized for paper substrates. Paper has excellent mechanical flexibility but can crinkle and deform under too much stress. paper is made of cellulose fibrils, arranged in a disorganized manner creating micro-cavities that can scatter light: ${ }^{73,74}$ This hinders its optical transparency. Coatings will not induce transparency so it is paramount to figure out how to chemically tune or modify the morphology of cellulose fibres. Oxidation on cellulose can be performed by TEMPO (figure 27) to morph it into a highly packed structure ${ }^{75}$ 


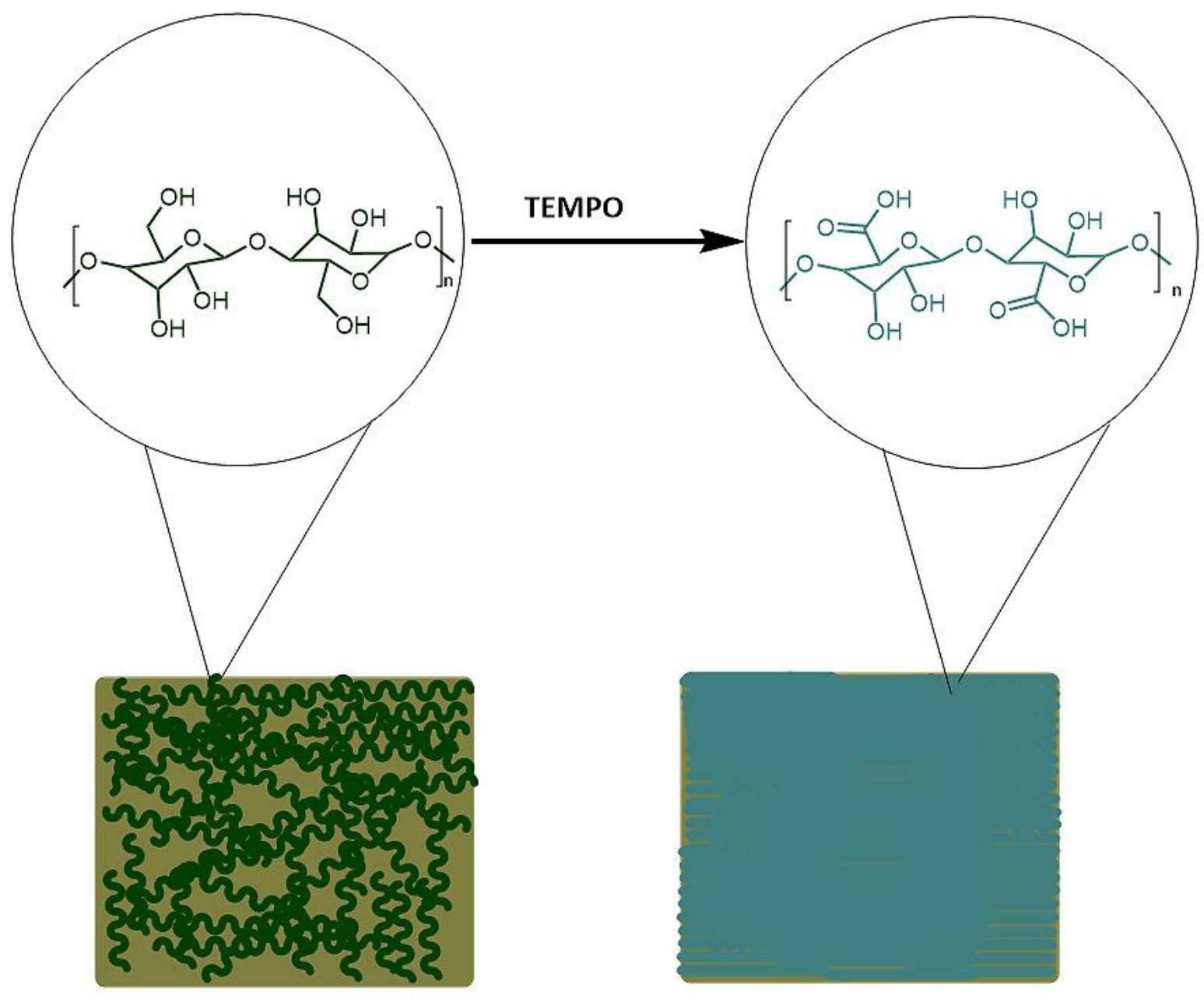

Figure 26 Regular paper has unevenly spaced cellulose fibres with microgaps that reflect light(left), oxidation allows the cellulose fibres to contract and close the gaps (right). ${ }^{74}$

The transmittance of TEMPO,(2,2,6,6-tetramethylpiperidin-1-yl)oxidanyl, oxidized paper is very high (96\%). ${ }^{74}$ The modification also showed improved mechanical properties (higher tensile strength and toughness) over regular paper. ${ }^{74}$ Overall the wet chemistry to treat regular paper with the TEMPO system lasted only 3-4 hours ${ }^{59}$ and is a cost-effective method for designing transparent paper.

Paper has a significantly higher permeability than plastics $\left(\right.$ a WVTR of $\left.359 \mathrm{~g} / \mathrm{m}^{2}\right) ;^{76}$ various coatings have been applied and the best obtained WVTR was $104 \mathrm{~g} / \mathrm{m}^{2}{ }^{61}$ It was interesting that the study done by on TEMPO oxidized paper $^{59}$ et al did not look into moisture and oxygen permeability 
for their densely packed cellulose paper: It would have been an intuitive direction to take for that research and will be required since moisture reduces the durability of DSSCs.

It is possible as a proof-of-concept to 3-D print a DSSC. The actual direct-writing of the substrates will not be practical, as mentioned in the previous section. Nonetheless, direct-writing of materials to produce a DSSC is possible through inkjet printing. A high $\mathrm{T}_{\mathrm{g}}$ glass substrate can be substituted for paper in a printer. The conductive glasses (ITO and/or FTO) and the mesoporous titania layer can be written as a colloidal ink formulations. A major problem will be dye loading onto titania. Normally, the titania layer is soaked in a solution of the dye to allow complete penetration into its pores. If the dye is printed directly onto titania, dye loading will be insufficient and this will reduce the photocurrent. The traditional iodide/triiodide liquid electrolyte reduces cell durability and alternative solid state electrolytes are being looked into as candidates for its replacement. ${ }^{77}$ Our group has published on dyes that can be in-situ polymerized with EDOT monomers to form a solidstate device. A solution of EDOT can be loaded into a cartridge to be printed onto the dye-loaded titania. This printing should be done under the exposure of light (the onset of absorption) to photopolymerize EDOT onto the pendant thiophene arms. A solid state DSSC will be competitive with silicon panels once its durability has been increased. Due to the similarities between the dyes in our original publication and the benchmark dye $\mathbf{L} \mathbf{1 / 1}$, it is necessary to furnish a new family of dyes with polymerizable sub-units. The 3-substituted thiophene arms performed the best so they are prime candidates to attach to the best performing dye of our new bichromic and bipodal family (figure 28). 


\section{$\underline{\text { References }}$}

(1) Kander, A. Economic growth, energy consumption and CO 2 emissions in Sweden 1800-2000; 2000.

(2) Asafu-Adjaye, J. Energy Econ. 2000, 615.

(3) Hoffert, M. I.; Caldeira, K.; Jain, a. K.; Haites, E. F.; Harvey, L. D. D.; Potter, S. D.; Schlesinger, M. E.; Schneider, S. H.; Watts, R. G.; Wigley, T. M. L.; Wuebbles, D. J. Nature 1998, 395 (October), 881.

(4) Lund, H. Energy 2007, 32 (6), 912.

(5) Mathiesen, B. V.; Lund, H.; Karlsson, K. Appl. Energy 2011, 88 (2), 488.

(6) Hoogwijk, M.; Faaij, A.; van den Broek, R.; Berndes, G.; Gielen, D.; Turkenburg, W. Biomass and Bioenergy 2003, 25 (2), 119.

(7) Feature, N. Nature 2008, 5 (August), 10.

(8) Hagfeldt, A.; Boschloo, G.; Sun, L.; Kloo, L.; Pettersson, H. Chem. Rev. 2010, 110 (11), 6595.

(9) Lewis, N. S.; Crabtree, G.; Nozik, A. J.; Wasielewski, M. R.; Alivisatos, P. Basic Energy Sci. Work. Sol. Energy Util. 2005, 276.

(10) Barkhouse, D. A. R.; Gunawan, O.; Gokmen, T.; Todorov, T. K.; Mitzi, D. B. Prog. Photovoltaics Res. Appl. 2012, 20 (1), 6.

(11) Fthenakis, V. M.; Bowerman, B. 3rd World Conf. onPhotovoltaic Energy Conversion, 2003. Proc. 2003, 1, 1.

(12) Burschka, J.; Pellet, N.; Moon, S.-J.; Humphry-Baker, R.; Gao, P.; Nazeeruddin, M. K.; Grätzel, M. Nature 2013, 499 (7458), 316.

(13) Kalowekamo, J.; Baker, E. Sol. Energy 2009, 83 (8), 1224.

(14) Nazeeruddin, M. K.; Kay, a; Miiller, E.; Liska, P.; Vlachopoulos, N.; Gratzel, M.; Lausanne, C.-; April, R. J. Am. Chem. Soc. 1993, 115 (4), 6382.

(15) O’Regan, B. C.; Durrant, J. R. Acc. Chem. Res. 2009, 42 (11), 1799.

(16) Boschloo, G.; Hagfeldt, A. Acc. Chem. Res. 2009, 42 (11), 1819.

(17) Hu, K.; Robson, K. C. D.; Johansson, P. G.; Berlinguette, C. P.; Meyer, G. J. J. Am. Chem. Soc. 2012, 134 (20), 8352. 
(18) Wang, H.; Liu, M.; Zhang, M.; Wang, P.; Miura, H.; Cheng, Y.; Bell, J. Phys. Chem. Chem. Phys. 2011, 13 (38), 17359.

(19) Tian, H.; Yu, Z.; Hagfeldt, A.; Kloo, L.; Sun, L. J. Am. Chem. Soc. 2011, 133 (24), 9413.

(20) Yum, J.-H.; Chen, P.; Grätzel, M.; Nazeeruddin, M. K. ChemSusChem 2008, 1 (8-9), 699.

(21) Pedersen, T.; Johansen, P.; Pedersen, H. Phys. Rev. B 2000, 61 (15), 10504.

(22) Simon, D. A. M. and J. D. Physical Chemistry: A Molecular Approach.

(23) Chen, J.; Wang, M. Chem. Res. Chinese Univ. 2013, 29 (3), 584.

(24) Sakong, C.; Kim, H. J.; Kim, S. H.; Namgoong, J. W.; Park, J. H.; Ryu, J.-H.; Kim, B.; Ko, M. J.; Kim, J. P. New J. Chem. 2012, 36 (10), 2025.

(25) Zhang, M.-D.; Pan, H.; Ju, X.-H.; Ji, Y.-J.; Qin, L.; Zheng, H.-G.; Zhou, X.-F. Phys. Chem. Chem. Phys. 2012, 14 (8), 2809.

(26) Xu, M. F.; Li, R. Z.; Pootrakulchote, N.; Shi, D.; Guo, J.; Yi, Z. H.; Zakeeruddin, S. M.; Grätzel, M.; Wang, P.; Wang, Y. J. Phys. Chem. C 2008, 112 (44), 17046.

(27) Bonnier, C.; Machin, D. D.; Abdi, O. K.; Robson, K. C. D.; Koivisto, B. D. Org. Biomol. Chem. 2013, 11 (40), 7011.

(28) Kissinger, P. T.; Lafayette, W.; Heineman, W. R. No. d, 702.

(29) Evans, D. H.; O’Connell, K. M.; Petersen, R. a.; Kelly, M. J. J. Chem. Educ. 1983, 60 (4), 290.

(30) Mabboil, G. A. 1983, 60 (9), 697.

(31) Mabbot, G. A. J. Chem. Educ. 1983, 60, 290.

(32) Mishra, A.; Fischer, M. K. R.; Büuerle, P. Angew. Chemie - Int. Ed. 2009, 48 (14), 2474.

(33) Yang, Z.; Shao, C.; Cao, D. RSC Adv. 2015, 5 (29), 22892.

(34) Bonnier, C.; Machin, D. D.; Abdi, O.; Koivisto, B. D. Org. Biomol. Chem. 2013, 11 (22), 3756.

(35) Lu, M.; Liang, M.; Han, H. Y.; Sun, Z.; Xue, S. J. Phys. Chem. C 2011, 115, 274.

(36) Liang, M.; Chen, J. Arylamine organic dyes for dye-sensitized solar cells.; 2013; Vol. 42.

(37) Yurchenko, O.; Freytag, D.; zur Borg, L.; Zentel, R.; Heinze, J.; Ludwigs, S. J. Phys. Chem. B 2012, 116 (1), 30. 
(38) Edvinsson, T.; Hagfeldt, A.; Boschloo, G. 2007, 1035.

(39) O’Regan, B.; Grätzel, M. Nature 1991, 353 (6346), 737.

(40) Armel, V.; Pringle, J. M.; Forsyth, M.; Macfarlane, D. R.; Officer, D. L.; Wagner, P. Chem. Commun. (Camb). 2010, 46 (18), 3146.

(41) Chung, I.; Lee, B.; He, J.; Chang, R. P. H.; Kanatzidis, M. G. Nature 2012, 485 (7399), 486.

(42) Yanagida, S.; Yu, Y.; Manseki, K. Acc. Chem. Res. 2009, 42 (11), 1827.

(43) Leandri, V.; Ruffo, R.; Trifiletti, V.; Abbotto, A. European J. Org. Chem. 2013, 2013 (30), 6793.

(44) Jean, R. Acc. Chem. Res. 2009, 42 (11), 1719.

(45) Mishra, A.; Bäuerle, P. Angew. Chemie - Int. Ed. 2012, 51 (9), 2020.

(46) Sun, Y.; Welch, G. C.; Leong, W. L.; Takacs, C. J.; Bazan, G. C.; Heeger, A. J. Nat. Mater. 2011, 11 (1), 44.

(47) Sun, X.; Liu, Y.; Xu, X.; Yang, C.; Yu, G.; Chen, S.; Zhao, Z.; Qiu, W.; Li, Y.; Zhu, D. J. Phys. Chem. B 2005, 109 (21), 10786.

(48) Jose, R.; Kumar, a.; Thavasi, V.; Fujihara, K.; Uchida, S.; Ramakrishna, S. Appl. Phys. Lett. 2008, $93(2), 023125$.

(49) Thavasi, V.; Renugopalakrishnan, V.; Jose, R.; Ramakrishna, S. Mater. Sci. Eng. R Reports 2009, $63(3), 81$.

(50) Ooyama, Y.; Harima, Y. European J. Org. Chem. 2009, No. 18, 2903.

(51) Robson, K. C. D.; Koivisto, B. D.; Yella, A.; Sporinova, B.; Nazeeruddin, M. K.; Baumgartner, T.; Grätzel, M.; Berlinguette, C. P. Inorg. Chem. 2011, 50 (12), 5494.

(52) Kanaparthi, R. K.; Kandhadi, J.; Giribabu, L. Tetrahedron 2012, 68 (40), 8383.

(53) Liang, M.; Chen, J. Arylamine organic dyes for dye-sensitized solar cells.; 2013; Vol. 42.

(54) Hagberg, D. P.; Marinado, T.; Karlsson, K. M.; Nonomura, K.; Qin, P.; Boschloo, G.; Brinck, T.; Hagfeldt, A.; Sun, L. J. Org. Chem. 2007, 72 (25), 9550.

(55) Hwang, S.; Lee, J. H.; Park, C.; Lee, H.; Kim, C.; Park, C.; Lee, M.-H.; Lee, W.; Park, J.; Kim, K.; Park, N.-G.; Kim, C. Chem. Commun. 2007, No. 46, 4887.

(56) Liang, M.; Xu, W.; Cai, F.; Chen, P.; Peng, B.; Chen, J. 2007, 4465. 
(57) Hsieh, C.-P.; Lu, H.-P.; Chiu, C.-L.; Lee, C.-W.; Chuang, S.-H.; Mai, C.-L.; Yen, W.-N.; Hsu, S.-J.; Diau, E. W.-G.; Yeh, C.-Y. J. Mater. Chem. 2010, 20 (6), 1127.

(58) Zeng, W.; Cao, Y.; Bai, Y.; Wang, Y.; Shi, Y.; Zhang, M.; Wang, F.; Pan, C.; Wang, P. Chem. Mater. 2010, 22 (5), 1915.

(59) Hong, Y. P.; Liao, J. Y.; Cao, D. R.; Zang, X. F.; Kuang, D. B.; Wang, L. Y.; Meier, H.; Su, C. Y. J. Org. Chem. 2011, 76, 8015.

(60) Yousaf, M.; Lough, a. J.; Schott, E.; Koivisto, B. D. RSC Adv. 2015, 5 (71), 57490.

(61) Yang, C.-H.; Liao, S.-H.; Sun, Y.-K.; Chuang, Y.-Y.; Wang, T.-L.; Shieh, Y.-T.; Lin, W.-C. J. Phys. Chem. C 2010, 114 (49), 21786.

(62) Oum, K.; Flender, O.; Lohse, P. W.; Scholz, M.; Hagfeldt, A.; Boschloo, G.; Lenzer, T. Phys. Chem. Chem. Phys. 2014, 16 (17), 8019.

(63) Tian, H.; Yang, X.; Chen, R.; Zhang, R.; Hagfeldt, A.; Sun, L. J. Phys. Chem. C 2008, 112 (29), 11023.

(64) Cummins, G.; Desmulliez, M. P. Y. Circuit World 2012, 38 (4), 193.

(65) Bosch-Jimenez, P.; Yu, Y.; Lira-Cantu, M.; Domingo, C.; Ayllón, J. a. J. Colloid Interface Sci. 2014, $416,112$.

(66) Hench, L. L.; West, J. K. Chem. Rev. 1990, 90 (1), 33.

(67) Duoss, E. B.; Twardowski, M.; Lewis, J. a. Adv. Mater. 2007, 19 (21), 3485.

(68) Flat, F.; Displays, P.; Wiley, J. No Title.

(69) Aga, R. S.; Lombardi, J. P.; Bartsch, C. M.; Member, S.; Heckman, E. M. 2014, 26 (3), 305.

(70) Garner, S. M.; Fong, H. H.; He, M.; Cimo, P.; Li, X.; Cai, Y.; Ouyang, S.; Xie, Y.; Shi, Q.; Cai, S. 2013 IEEE Photonics Conf. 2013, 1, 176.

(71) Peng, C.-Y.; Dhakal, T. P.; Garner, S.; Cimo, P.; Lu, S.; Westgate, C. R. Thin Solid Films 2014, 3.

(72) Fowkes, F. M. .

(73) Bollström, R.; Pettersson, F.; Dolietis, P.; Preston, J.; Österbacka, R.; Toivakka, M. Nanotechnology 2014, 25 (9), 094003.

(74) Fang, Z.; Zhu, H.; Yuan, Y.; Ha, D.; Zhu, S.; Preston, C.; Chen, Q.; Li, Y.; Han, X.; Lee, S.; Chen, G.; Li, T.; Munday, J.; Huang, J.; Hu, L. Nano Lett. 2014, 14 (2), 765. 
(75) Zhu, H.; Fang, Z.; Preston, C.; Li, Y.; Hu, L. Energy Environ. Sci. 2014, 7 (1), 269.

(76) Russo, A.; Ahn, B. Y.; Adams, J. J.; Duoss, E. B.; Bernhard, J. T.; Lewis, J. a. Adv. Mater. 2011, 23 (30), 3426.

(77) Bonnier, C.; Machin, D. D.; Abdi, O. K.; Robson, K. C. D.; Koivisto, B. D. Org. Biomol. Chem. 2013, $11(40), 7011$. 


\title{
Supporting Information for
}

Organic and Biomolecular Chemistry

\section{The Effect of Donor-modification in Organic Light-harvesting Motifs: Triphenylamine Donors Appended with Polymerisable Thienyl Subunits}

\author{
by
}

Catherine Bonnier, Devin D. Machin, Omar K. Abdi, Kiyoshi C. D. Robson, and Bryan D. Koivisto*

\author{
bryan.koivisto@ryerson.ca
}

\section{$\underline{\text { Table of Contents }}$}

General Considerations and Device Fabrication

p. S2

Figure S1 and Figure S2

p. S3

Experimental Procedures and Characterisation

p. S4 - S12

References

p. $\mathrm{S} 13$

${ }^{1} \mathrm{H}$ and ${ }^{13} \mathrm{C}\left\{{ }^{1} \mathrm{H}\right\}$ NMR Spectra

p. $S 14-S 40$

\section{General Considerations}


All reagents were purchased from Aldrich except $\mathrm{Pd}\left(\mathrm{PPh}_{3}\right)_{4}$ (Pressure Chemical Co., Pittsburg, PA). Purification by column chromatography was carried out using silica (Silicycle: ultrapure flash silica). Analytical thin-layer chromatography was performed on aluminum-backed sheets precoated with silica $60 \mathrm{~F} 254$ adsorbent $(0.25 \mathrm{~mm}$ thick; Silicycle) and visualized under UV light. IR data was collected in $\mathrm{KBr}$ using a Perkin Elmer Spectrum 1 Fourier Transform Infrared spectrophotometer. Melting points were determined using a Fisher-Johns Melting Point Apparatus. Cyclic voltammetry data was collected using a MetrOhm $\mu$-Autolab Type III potentiostat/galvanostat and UV-Vis absorption profiles were collected using an Agilent Cary 5000 UV-vis-NIR spectrophotometer. Routine ${ }^{1} \mathrm{H},{ }^{13} \mathrm{C}\left\{{ }^{1} \mathrm{H}\right\}$, NMR spectra were recorded at 400 and $100 \mathrm{MHz}$, respectively, on a Bruker AV 400 instrument at ambient temperature. Chemical shifts $(\delta)$ are reported in parts per million (ppm) from low to high field and referenced to a residual nondeuterated solvent $\left(\mathrm{CHCl}_{3}\right)$ for ${ }^{1} \mathrm{H}$ and ${ }^{13} \mathrm{C}$ nuclei. Standard abbreviations indicating multiplicity are used as follows: $\mathrm{s}=$ singlet; $\mathrm{d}=$ doublet; $\mathrm{m}=$ multiplet; $b r=$ broad. DFT calculations were performed using Gaussian 09M version C. 4,4,5,5tetramethyl-2-(thiophen-2-yl)-1,3,2-dioxaborolane $(\boldsymbol{A})^{1}, \quad 2$-(5-(1,3-dioxolan-2-yl)thiophen-2-yl)-4,4,5,5tetramethyl-1,3,2-dioxaborolane $(\boldsymbol{C})^{2}$, ethyl (2,5-dibromothiophene-3-yl)methyl(methyl)phosphinate $(D)^{3}$, and compounds $\mathbf{1}^{4}, \mathbf{2} a^{5}, \mathbf{2} b^{6}$ and $9 a^{7}$ and $9 b^{8}$ were prepared as previously reported.

Cell Fabrication. Photoanodes were fabricated by screen-printing methods on fluorine-doped tinoxide [FTO; Hartford Glass; TEC $8\left(8 \Omega \mathrm{cm}^{-2}\right)$ ] using 2 layers of $18 \mathrm{NR}-\mathrm{T}$ ( $20 \mathrm{~nm}$ particles, $12 \mu \mathrm{m}$ thick), and 1 layer of WER4-O (100 nm particles, $6 \mu \mathrm{m}$ thick) for a total thickness of $18 \mu \mathrm{m}$. The FTO glass was cleaned by sonication in a detergent solution for $30 \mathrm{~min}$ followed by subsequent rinsing with

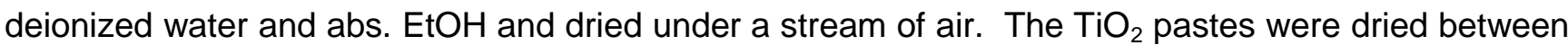
layers in an oven at $120^{\circ} \mathrm{C}$ for $25 \mathrm{~min}$. Once the desired thickness had been achieved, the anode was fired to $450{ }^{\circ} \mathrm{C}$ for $20 \mathrm{~min}$ in an ambient atmosphere and left to room temperature. The $\mathrm{TiO}_{2}$ substrates were treated with $\mathrm{TiCl}_{4}(\mathrm{aq})(0.05 \mathrm{M})$ at $70{ }^{\circ} \mathrm{C}$ for $30 \mathrm{~min}$ and subsequently rinsed with $\mathrm{H}_{2} \mathrm{O}$ and then dried prior to heating. The electrodes were heated to $450{ }^{\circ} \mathrm{C}$ for $20 \mathrm{~min}$ in an ambient atmosphere and left to cool to $80^{\circ} \mathrm{C}$ prior to immersing into a $\mathrm{CHCl}_{3}$ solution containing the dye $(0.25$ $\mathrm{mM})$ and chenodeoxycholic acid $(2.5 \mathrm{mM})$ for $16 \mathrm{~h}$. The stained films were then rinsed with copious amounts of $\mathrm{CHCl}_{3}$ and dried. The cells were fabricated using Pt-coated counter-electrode [FTO TEC$\left.15\left(15 \Omega \mathrm{cm}^{-2}\right)\right]$ and sealed with a $30 \mu \mathrm{m}$ Surlyn (Dupont) gasket by resistive heating. The Z1137 electrolyte used for this study was $\mathrm{I}_{3}^{-} / \mathrm{I}^{-}$[1.0 M 1,3- dimethylimidazolium iodide (DMII), $60 \mathrm{mM} \mathrm{I}, 0.5 \mathrm{M}$ tert-butylpyridine, $0.05 \mathrm{M} \mathrm{Nal}$ and $0.1 \mathrm{M}$ GuNCS in a mixed solvent system of acetonitrile and valeronitrile $(85: 15, v / v)]$. The electrolyte was introduced into the two-sandwiched electrodes via vacuum backfilling through a hole in the counter electrode. In the cases where the $\mathrm{I}_{3}^{-} / \mathrm{I}^{-}$electrolyte was used, the hole was sealed with an aluminum-backed Bynel $\circledast$ foil (Dyesol ${ }^{\mathrm{TM}}$ ). The active area of the $\mathrm{TiO}_{2}$ was $0.26 \mathrm{~cm}^{2}$. Silver bus bars were added to all cells after sealing. Dyes devices were made and tested in triplicate with standard deviations in device efficiency not exceeding $+/-0.2 \%$ 


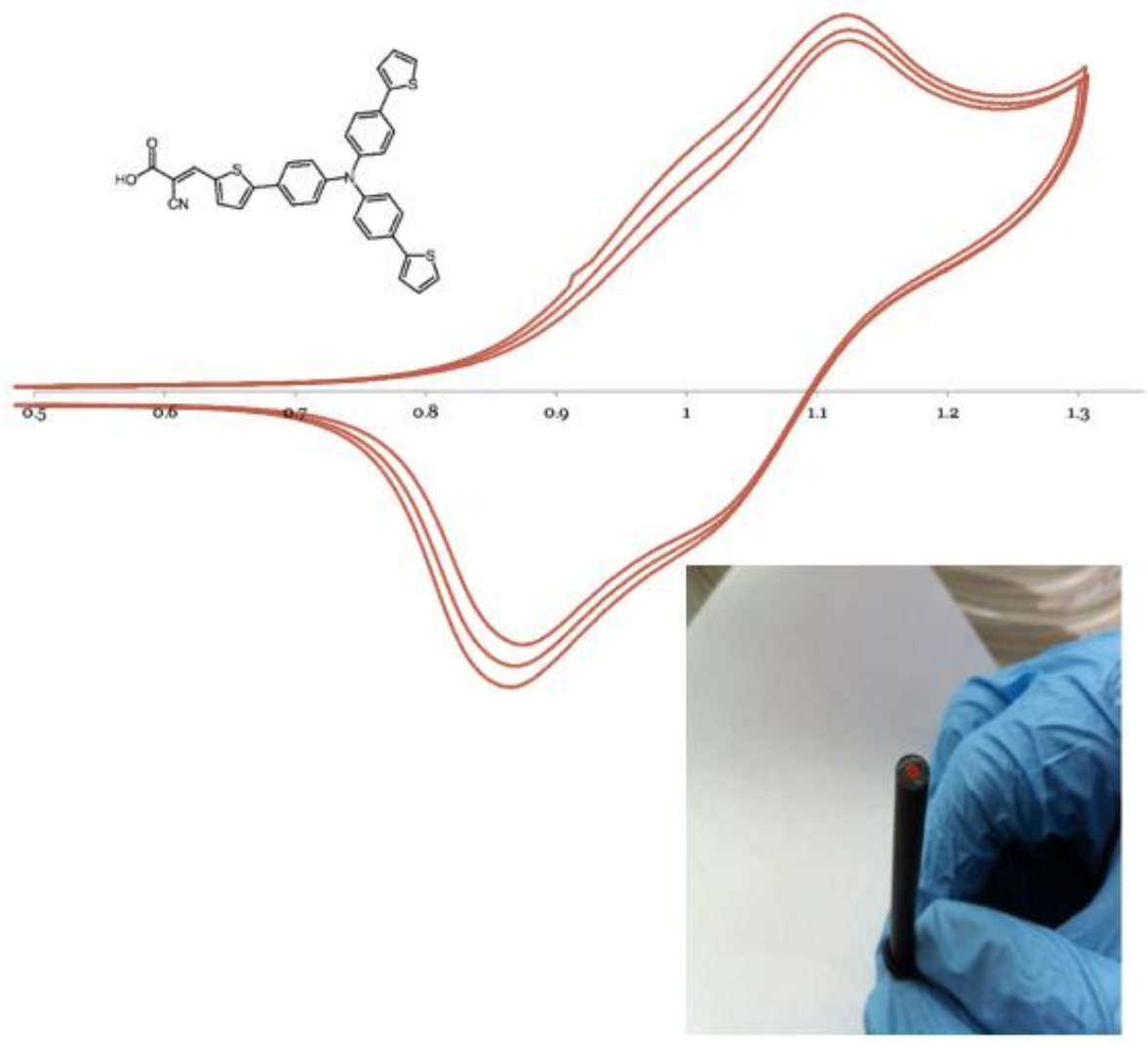

Figure S1. Film formation at the electrode surface. Cyclic voltammetry scans 10, 11 and 12 for dye $4 b$. 


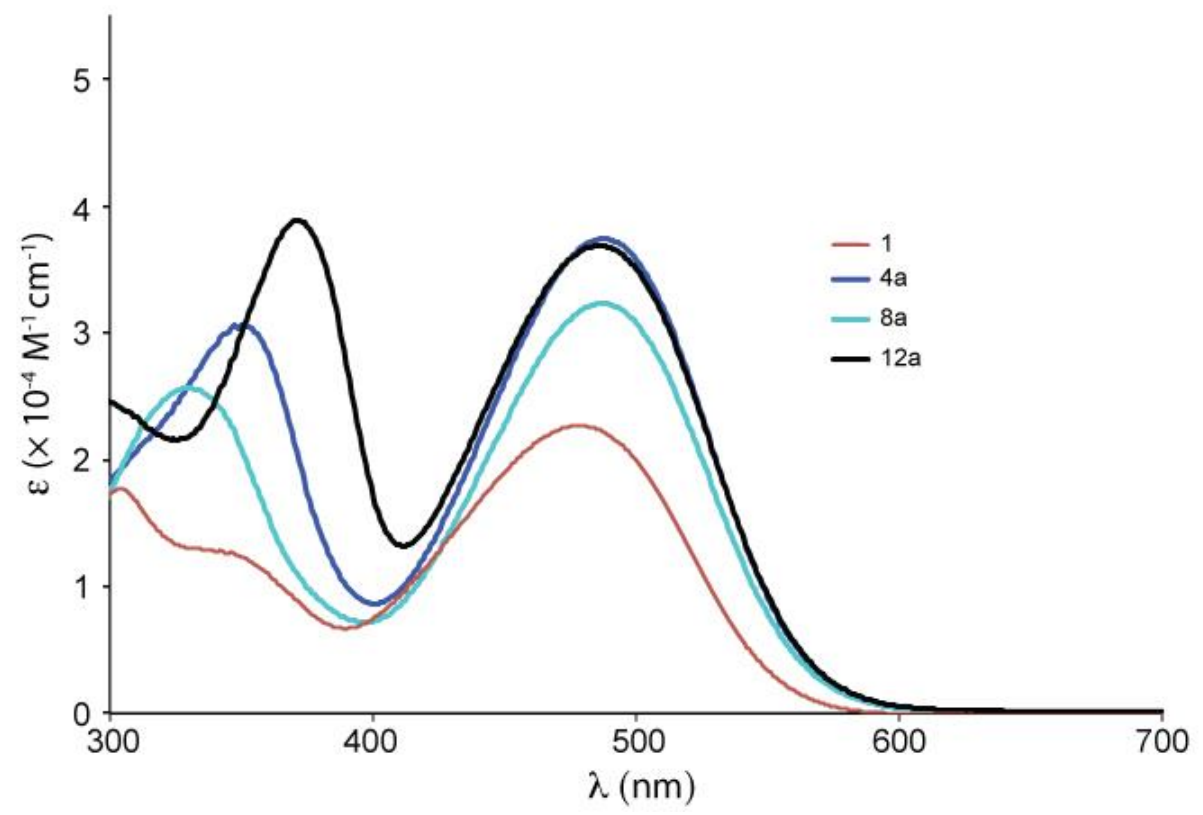

Figure S2. UV-vis spectra in DCM for the mono-substituted TPA dyes 4a, 8a, 12b and benchmark dye 1. 


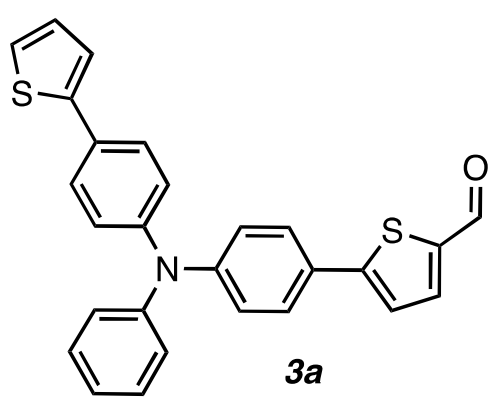

Synthesis of 3a: Under an atmosphere of $\mathrm{N}_{2}, 2 \boldsymbol{a}(160 \mathrm{mg}, 0.37 \mathrm{mmol})$ and $\boldsymbol{A}(89 \mathrm{mg}, 0.42 \mathrm{mmol})$ were dissolved in $55 \mathrm{~mL}$ of a mixture of THF: $\mathrm{H}_{2} \mathrm{O} 9: 1$ and the solution was sparged 10 min with $\mathrm{N}_{2}$. $\mathrm{K}_{2} \mathrm{CO}_{3}(254 \mathrm{mg}, 1.84 \mathrm{mmol})$ and $\mathrm{Pd}\left(\mathrm{PPh}_{3}\right)_{4}(43 \mathrm{mg}, 0.037 \mathrm{mmol})$ were added and the mixture was refluxed $12 \mathrm{~h}$. After being cooled to room temperature, $50 \mathrm{~mL}$ of $\mathrm{H}_{2} \mathrm{O}$ were added and the organic layer was separated. The aqueous layer was extracted with $\mathrm{Et}_{2} \mathrm{O}(3 \times 25 \mathrm{~mL})$ and the combined organic layers were dried over $\mathrm{MgSO}_{4}$, filtered and volatiles were removed in vacuo. The crude material was purified via column chromatography using $\mathrm{CH}_{2} \mathrm{Cl}_{2}$ as the eluent, affording the desired product as a yellow solid (110 mg, $68 \%)$. Mp 123-124 ${ }^{\circ} \mathrm{C}$; IR $\left(\mathrm{KBr}, \mathrm{cm}^{-1}\right)$ 1664. ${ }^{1} \mathrm{H} \mathrm{NMR}(400 \mathrm{MHz}$, acetone- $\left.\mathrm{d}_{6}\right): \delta=9.91(\mathrm{~m}, 1 \mathrm{H}), 7.94\left(\mathrm{~d}, 1 \mathrm{H},{ }^{3} \mathrm{~J}_{\mathrm{HH}}=3.9 \mathrm{~Hz}\right), 7.72\left(\mathrm{~d}, 2 \mathrm{H},{ }^{3} \mathrm{~J}_{\mathrm{HH}}=8.8 \mathrm{~Hz}\right), 7.65\left(\mathrm{~d}, 2 \mathrm{H},{ }^{3} \mathrm{~J}_{\mathrm{HH}}\right.$ $=8.6 \mathrm{~Hz}), 7.58(\mathrm{~d}, 1 \mathrm{H}), 7.40(\mathrm{~m}, 4 \mathrm{H}), 7.15(\mathrm{~m}, 8 \mathrm{H}) \cdot{ }^{13} \mathrm{C}\left\{{ }^{1} \mathrm{H}\right\}$ NMR $\left(100 \mathrm{MHz}\right.$, acetone- $\left.\mathrm{d}_{6}\right): \delta=183.7$, $154.1,149.7,147.7,147.3,144.5,142.7,139.3,130.6,129.1,128.3,128.2,128.1,127.7,127.6$, 126.3, 126.1, 126.0, 125.8, 125.5, 125.2, 124.5, 123.8, 123.6. HRMS (DART): $\mathrm{m} / \mathrm{z} 438.0994\left[(\mathrm{M}+\mathrm{H})^{+}\right]$, calcd for ${ }^{12} \mathrm{C}_{27}{ }^{1} \mathrm{H}_{20}{ }^{14} \mathrm{~N}^{16} \mathrm{O}^{32} \mathrm{~S}_{2}{ }^{+}: \mathrm{m} / \mathrm{z} 438.0986$.

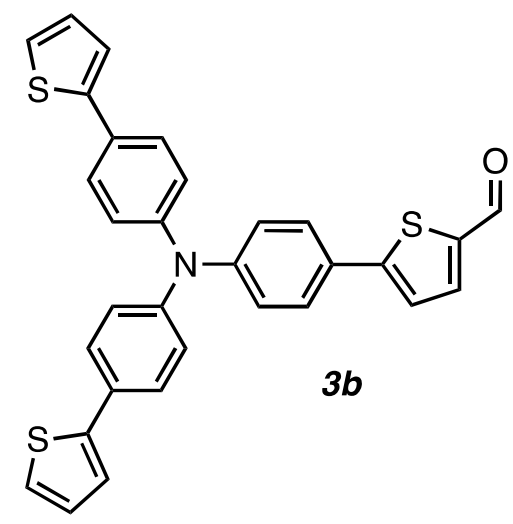

Synthesis of $\boldsymbol{3} \boldsymbol{b}$ : Under an atmosphere of $\mathrm{N}_{2}, \boldsymbol{2} \boldsymbol{b}(294 \mathrm{mg}, 0.57 \mathrm{mmol})$ and $\boldsymbol{A}(275 \mathrm{mg}, 1.31 \mathrm{mmol})$ were dissolved in $55 \mathrm{~mL}$ of a mixture of THF: $\mathrm{H}_{2} \mathrm{O} 9: 1$ and the solution was sparged 10 min with $\mathrm{N}_{2}$. 
$\mathrm{K}_{2} \mathrm{CO}_{3}(788 \mathrm{mg}, 5.7 \mathrm{mmol})$ and $\mathrm{Pd}\left(\mathrm{PPh}_{3}\right)_{4}(132 \mathrm{mg}, 0.144 \mathrm{mmol})$ were added and the mixture was refluxed $12 \mathrm{~h}$. After being cooled to room temperature, $25 \mathrm{~mL}$ of $\mathrm{H}_{2} \mathrm{O}$ were added and the organic layer was separated. The aqueous layer was extracted with $\mathrm{Et}_{2} \mathrm{O}(3 \times 25 \mathrm{~mL})$ and the combined organic layers were dried over $\mathrm{MgSO}_{4}$, filtered and volatiles were removed in vacuo. The crude material was purified via column chromatography using $\mathrm{CH}_{2} \mathrm{Cl}_{2}$ as the eluent, affording the desired product as a yellow solid (192 mg, $65 \%)$. Mp 98-100 ${ }^{\circ} \mathrm{C}$; IR $\left(\mathrm{KBr}, \mathrm{cm}^{-1}\right) 1663 .{ }^{1} \mathrm{H} \mathrm{NMR}(400 \mathrm{MHz}$, acetone- $\left.\mathrm{d}_{6}\right): \delta=9.92(\mathrm{~s}, 1 \mathrm{H}), 7.96\left(\mathrm{~d}, 1 \mathrm{H},{ }^{3} \mathrm{~J}_{\mathrm{HH}}=4.0 \mathrm{~Hz}\right), 7.75\left(\mathrm{~d}, 2 \mathrm{H},{ }^{3} \mathrm{~J}_{\mathrm{HH}}=8.7 \mathrm{~Hz}\right), 7.67\left(\mathrm{~d}, 4 \mathrm{H},{ }^{3} \mathrm{~J}_{\mathrm{HH}}\right.$ $=8.6 \mathrm{~Hz}), 7.60(\mathrm{~d}, 1 \mathrm{H}), 7.43(\mathrm{~d}, 4 \mathrm{H}), 7.19(\mathrm{~m}, 6 \mathrm{H}), 7.12(\mathrm{~m}, 2 \mathrm{H}) .{ }^{13} \mathrm{C}\left\{{ }^{1} \mathrm{H}\right\} \mathrm{NMR}\left(100 \mathrm{MHz}\right.$, acetone- $\left.\mathrm{d}_{6}\right)$ : $\delta=183.7,154.0,149.3,147.0,144.4,142.8,139.4,131.0,129.2,128.3,128.0,127.7,126.1,125.6$, 124.7, 124.1, 123.9. HRMS (DART): $\mathrm{m} / \mathrm{z} 520.0860\left[(\mathrm{M}+\mathrm{H})^{+}\right]$, calcd for ${ }^{12} \mathrm{C}_{31}{ }^{1} \mathrm{H}_{22}{ }^{14} \mathrm{~N}^{16} \mathrm{O}^{32} \mathrm{~S}_{3}{ }^{+}: \mathrm{m} / \mathrm{z}$ 520.0864 .

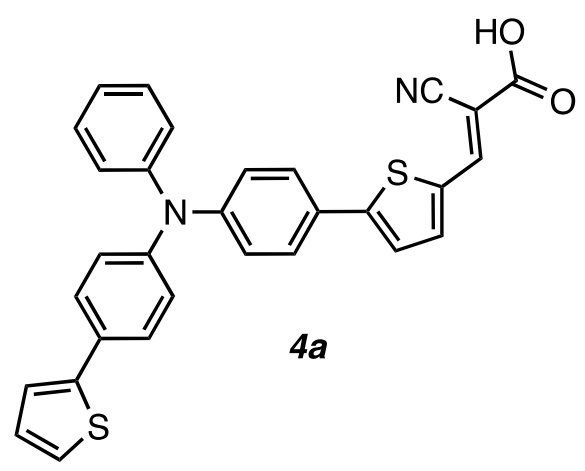

Synthesis of $4 a$ : $3 a(50 \mathrm{mg}, 0.11 \mathrm{mmol})$ was dissolved in $25 \mathrm{~mL}$ of $\mathrm{CHCl}_{3}$ and cyanoacetic acid (19 $\mathrm{mg}, 0.22 \mathrm{mmol})$ was added, followed by piperidine $(3 \mu \mathrm{L}, 0.03 \mathrm{mmol})$. The mixture was refluxed $12 \mathrm{~h}$ and after being cooled at room temperature, the organic layer was washed with $\mathrm{HCl} 1 \mathrm{~N}(3 \times 25 \mathrm{~mL})$. The organic layer was dried over $\mathrm{MgSO}_{4}$, filtered and volatiles were removed in vacuo. The crude product was recrystallized from hexanes: $\mathrm{CH}_{2} \mathrm{Cl}_{2} 3: 1$, affording the desired product as a dark red solid (49 mg, $88 \%)$. Mp 168-171 ${ }^{\circ} \mathrm{C}$; IR $\left(\mathrm{KBr}, \mathrm{cm}^{-1}\right)$ 2217, 1686. ${ }^{1} \mathrm{H}$ NMR $\left(400 \mathrm{MHz}\right.$, acetone- $\left.\mathrm{d}_{6}\right): \delta=8.42$ $(\mathrm{s}, 1 \mathrm{H}), 7.97\left(\mathrm{~d}, 1 \mathrm{H},{ }^{3} \mathrm{~J}_{\mathrm{HH}}=3.9 \mathrm{~Hz}\right), 7.75\left(\mathrm{~d}, 2 \mathrm{H},{ }^{3} \mathrm{~J}_{\mathrm{HH}}=8.7 \mathrm{~Hz}\right), 7.64(\mathrm{~m}, 3 \mathrm{H}), 7.39(\mathrm{~m}, 4 \mathrm{H}), 7.16(\mathrm{~m}$, $8 \mathrm{H}) .{ }^{13} \mathrm{C}\left\{{ }^{1} \mathrm{H}\right\} \mathrm{NMR}\left(100 \mathrm{MHz}\right.$, acetone- $\left.\mathrm{d}_{6}\right): \delta=154.8,149.9,147.6,147.4,147.2,144.5,141.6,135.0$, $130.8,130.6,130.5,129.1,128.3,127.7,126.4,126.2,125.9,125.5,125.3,124.6,123.8,123.4$, 117.0, $\quad C=\mathrm{O}$ signal not detected. HRMS (DART): $\mathrm{m} / \mathrm{z} 505.1041 \quad\left[(\mathrm{M}+\mathrm{H})^{+}\right]$, calcd for ${ }^{12} \mathrm{C}_{30}{ }^{1} \mathrm{H}_{21}{ }^{14} \mathrm{~N}_{2}{ }^{16} \mathrm{O}_{2}{ }^{32} \mathrm{~S}_{2}{ }^{+}: \mathrm{m} / \mathrm{z} 505.1044$. 


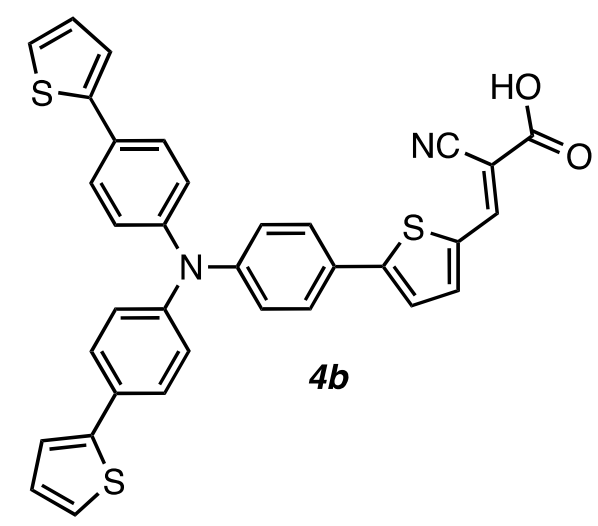

Synthesis of $4 \boldsymbol{b}: \mathbf{3 b}\left(50 \mathrm{mg}, 0.10 \mathrm{mmol}\right.$ ) was dissolved in $25 \mathrm{~mL}$ of $\mathrm{CHCl}_{3}$ and cyanoacetic acid (16 $\mathrm{mg}, 0.19 \mathrm{mmol}$ ) was added, followed by piperidine $(3 \mu \mathrm{L}, 0.03 \mathrm{mmol})$. The mixture was refluxed $12 \mathrm{~h}$ and after being cooled at room temperature, the organic layer was washed with $\mathrm{HCl} 1 \mathrm{~N}(3 \times 25 \mathrm{~mL})$. The organic layer was dried over $\mathrm{MgSO}_{4}$, filtered and volatiles were removed in vacuo. The crude product was recrystallized from hexanes: $\mathrm{CH}_{2} \mathrm{Cl}_{2} 3: 1$, affording the desired product as a dark red solid (53 mg, $90 \%)$. Mp 213-216 ${ }^{\circ} \mathrm{C}$; IR $\left(\mathrm{KBr}, \mathrm{cm}^{-1}\right)$ 2217, 1693. ${ }^{1} \mathrm{H}$ NMR $\left(400 \mathrm{MHz}\right.$, acetone- $\left.\mathrm{d}_{6}\right): \delta=8.39$ $(\mathrm{s}, 1 \mathrm{H}), 7.94\left(\mathrm{~d}, 1 \mathrm{H},{ }^{3} \mathrm{~J}_{\mathrm{HH}}=4.4 \mathrm{~Hz}\right), 7.77\left(\mathrm{~d}, 2 \mathrm{H},{ }^{3} \mathrm{~J}_{\mathrm{HH}}=8.6 \mathrm{~Hz}\right), 7.68\left(\mathrm{~d}, 4 \mathrm{H},{ }^{3} \mathrm{~J}_{\mathrm{HH}}=8.5 \mathrm{~Hz}\right), 7.63(\mathrm{~d}$, $1 \mathrm{H}), 7.44(\mathrm{~m}, 4 \mathrm{H}), 7.20(\mathrm{~m}, 6 \mathrm{H}), 7.13(\mathrm{~m}, 2 \mathrm{H})$. Compound was too insoluble to obtain ${ }^{13} \mathrm{C}\left\{{ }^{1} \mathrm{H}\right\}$ spectrum after $24 \mathrm{~h}$. HRMS (DART): $\mathrm{m} / \mathrm{z} 587.0925\left[(\mathrm{M}+\mathrm{H})^{+}\right]$, calcd for ${ }^{12} \mathrm{C}_{34}{ }^{1} \mathrm{H}_{23}{ }^{14} \mathrm{~N}_{2}{ }^{16} \mathrm{O}_{2}{ }^{32} \mathrm{~S}_{3}{ }^{+}: \mathrm{m} / \mathrm{z}$ 587.0922.

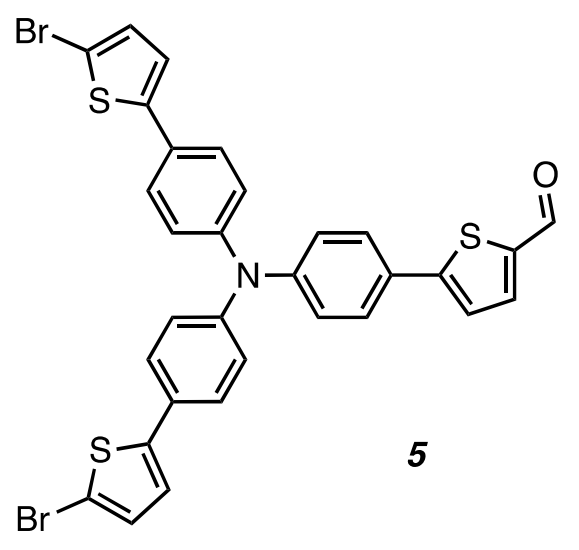

Synthesis of 5: Under an atmosphere of $\mathrm{N}_{2}, 3 \boldsymbol{b}(59 \mathrm{mg}, 0.11 \mathrm{mmol})$ was dissolved in $50 \mathrm{~mL}$ of a mixture of THF:EtOAc 1:1 and N-bromosuccinimide $(40 \mathrm{mg}, 0.23 \mathrm{mmol})$ was added. The mixture was stirred at room temperature for $12 \mathrm{~h}$ and volatiles were removed in vacuo. The crude product was purified via column chromatography using $\mathrm{CH}_{2} \mathrm{Cl}_{2}$ as the eluent, affording the desired compound as 
an orange solid (64 mg, $83 \%)$. Mp 157-159 ${ }^{\circ} \mathrm{C}$; IR $\left(\mathrm{KBr}, \mathrm{cm}^{-1}\right)$ 1667. ${ }^{1} \mathrm{H} \mathrm{NMR}\left(400 \mathrm{MHz}, \mathrm{CDCl}_{3}\right): \delta=$ $9.87(\mathrm{~s}, 1 \mathrm{H}), 7.73\left(\mathrm{~d}, 1 \mathrm{H},{ }^{3} \mathrm{~J}_{\mathrm{HH}}=3.9 \mathrm{~Hz}\right), 7.57\left(\mathrm{~d}, 2 \mathrm{H},{ }^{3} \mathrm{~J}_{\mathrm{HH}}=8.6 \mathrm{~Hz}\right), 7.43,\left(\mathrm{~d}, 4 \mathrm{H},{ }^{3} \mathrm{~J}_{\mathrm{HH}}=8.6 \mathrm{~Hz}\right), 7.34$ $(\mathrm{d}, 1 \mathrm{H}), 7.14(\mathrm{~d}, 2 \mathrm{H}), 7.13(\mathrm{~d}, 4 \mathrm{H}), 7.01(\mathrm{~m}, 4 \mathrm{H}) .{ }^{13} \mathrm{C}\left\{{ }^{1} \mathrm{H}\right\} \mathrm{NMR}\left(100 \mathrm{MHz}, \mathrm{CDCl}_{3}\right): \delta=182.8,154.2$, 148.3, 146.5, 145.4, 141.9, 137.8, 131.1, 129.4, 127.6, 127.5, 126.9, 125.2, 123.7, 123.4, 123.0, 111.1. HRMS (DART): $m / z 675.9077\left[(\mathrm{M}+\mathrm{H})^{+}\right]$, (calcd for ${ }^{12} \mathrm{C}_{31}{ }^{1} \mathrm{H}_{20}{ }^{79} \mathrm{Br}_{2}{ }^{14} \mathrm{~N}^{16} \mathrm{O}^{32} \mathrm{~S}_{3}{ }^{+}: \mathrm{m} / z 675.9074$.<smiles>N#C/C(=C\c1ccc(-c2ccc(N(c3ccc(-c4ccc(Br)s4)cc3)c3ccc(-c4ccc(Br)s4)cc3)cc2)s1)C(=O)O</smiles>

Synthesis of $6 \mathbf{b}: 5$ ( $50 \mathrm{mg}, 0.10 \mathrm{mmol}$ ) was dissolved in $25 \mathrm{~mL}$ of $\mathrm{CHCl}_{3}$ and cyanoacetic acid (16 $\mathrm{mg}, 0.19 \mathrm{mmol})$ was added, followed by piperidine $(2 \mu \mathrm{L}, 0.02 \mathrm{mmol})$. The mixture was refluxed $12 \mathrm{~h}$ and after being cooled at room temperature, the organic layer was washed with $\mathrm{HCl} 1 \mathrm{~N}(3 \times 25 \mathrm{~mL})$. The organic layer was dried over $\mathrm{MgSO}_{4}$, filtered and volatiles were removed in vacuo. The crude product was recrystallized from hexanes: $\mathrm{CH}_{2} \mathrm{Cl}_{2} 3: 1$, affording a dark red solid (49 mg, $89 \%$ ). Mp 169-170 ${ }^{\circ} \mathrm{C}$; IR $\left(\mathrm{KBr}, \mathrm{cm}^{-1}\right)$ 2217, 1687. ${ }^{1} \mathrm{H}$ NMR $\left(400 \mathrm{MHz}\right.$, acetone- $\left.\mathrm{d}_{6}\right): \delta=8.39(\mathrm{~s}, 1 \mathrm{H}), 7.94(\mathrm{~d}, 2 \mathrm{H}$, $\left.{ }^{3} \mathrm{~J}_{\mathrm{HH}}=4.4 \mathrm{~Hz}\right), 7.77(\mathrm{~d}, 2 \mathrm{H}, 8.6 \mathrm{~Hz}), 7.68\left(\mathrm{~d}, 4 \mathrm{H},{ }^{3} \mathrm{~J}_{\mathrm{HH}}=8.5 \mathrm{~Hz}\right), 7.63(\mathrm{~d}, 1 \mathrm{H}), 7.44(\mathrm{~m}, 3 \mathrm{H}), 7.20(\mathrm{~m}$, $6 \mathrm{H}), 7.12(\mathrm{~m}, 2 \mathrm{H})$. Compound was too insoluble to detect ${ }^{13} \mathrm{C}$ signals after $24 \mathrm{~h}$. HRMS (DART): $\mathrm{m} / \mathrm{z}$ $698.9243\left[\left(\mathrm{M}+\mathrm{H}-\mathrm{CO}_{2}\right)^{+}\right]$, calcd for ${ }^{12} \mathrm{C}_{33}{ }^{1} \mathrm{H}_{21}{ }^{79} \mathrm{Br}_{2}{ }^{14} \mathrm{~N}_{2}{ }^{32} \mathrm{~S}_{3}{ }^{+}: \mathrm{m} / \mathrm{z} 698.9234$.

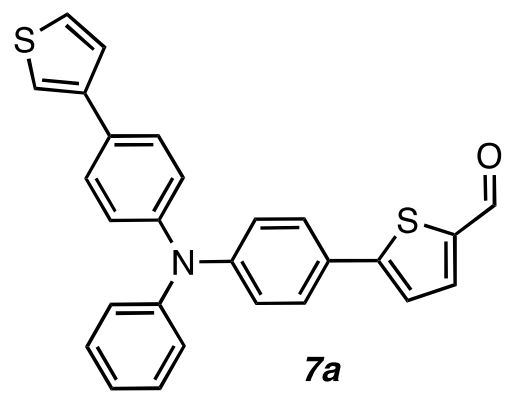

Synthesis of 7a: Under an atmosphere of $\mathrm{N}_{2}, 2 \boldsymbol{a}(200 \mathrm{mg}, 0.46 \mathrm{mmol})$ and $\boldsymbol{B}(68 \mathrm{mg}, 0.53 \mathrm{mmol})$ were dissolved in $55 \mathrm{~mL}$ of a mixture of THF: $\mathrm{H}_{2} \mathrm{O} 9: 1$ and the solution was sparged 10 min with $\mathrm{N}_{2}$. 
$\mathrm{K}_{2} \mathrm{CO}_{3}$ (318 mg, $\left.2.3 \mathrm{mmol}\right)$ and $\mathrm{Pd}\left(\mathrm{PPh}_{3}\right)_{4}(53 \mathrm{mg}, 0.046 \mathrm{mmol}$ ) were added and the mixture was refluxed $12 \mathrm{~h}$. After being cooled to room temperature, $50 \mathrm{~mL}$ of $\mathrm{H}_{2} \mathrm{O}$ were added and the organic layer was separated. The aqueous layer was extracted with $\mathrm{Et}_{2} \mathrm{O}(3 \times 25 \mathrm{~mL})$ and the combined organic layers were dried over $\mathrm{MgSO}_{4}$, filtered and volatiles were removed in vacuo. The crude material was purified via column chromatography using hexanes: $\mathrm{CH}_{2} \mathrm{Cl}_{2}$ 1:1 as the eluent, affording the desired product as a yellow solid (110 mg, 68\%). Mp 94-97 ${ }^{\circ} \mathrm{C}$; IR $\left(\mathrm{KBr}, \mathrm{cm}^{-1}\right)$ 1662. ${ }^{1} \mathrm{H}$ NMR $(400$ $\mathrm{MHz}$, acetone- $\left.\mathrm{d}_{6}\right): \delta=9.90(\mathrm{~m}, 1 \mathrm{H}), 7.94\left(\mathrm{~d}, 1 \mathrm{H},{ }^{3} \mathrm{~J}_{\mathrm{HH}}=4.0 \mathrm{~Hz}\right), 7.71(\mathrm{~m}, 5 \mathrm{H}), 7.56(\mathrm{~m}, 2 \mathrm{H}), 7.52(\mathrm{~m}$, $1 \mathrm{H}), 7.38(\mathrm{~m}, 2 \mathrm{H}), 7.17(\mathrm{~m}, 5 \mathrm{H}), 7.09\left(\mathrm{~d}, 2 \mathrm{H},{ }^{3} \mathrm{~J}_{\mathrm{HH}}=8.8 \mathrm{~Hz}\right) \cdot{ }^{13} \mathrm{C}\left\{{ }^{1} \mathrm{H}\right\} \mathrm{NMR}\left(100 \mathrm{MHz}\right.$, acetone- $\left.\mathrm{d}_{6}\right): \delta=$ 183.7, 154.2, 149.9, 147.8, 146.9, 142.6, 142.4, 139.4, 132.3, 130.6, 128.3, 128.2, 127.4, 127.3, 126.9, 126.2, 126.0, 125.1, 124.5, 123.3, 120.7. HRMS (DART): $\mathrm{m} / z 438.0986\left[(\mathrm{M}+\mathrm{H})^{+}\right]$, calcd for ${ }^{12} \mathrm{C}_{27}{ }^{1} \mathrm{H}_{20}{ }^{14} \mathrm{~N}^{16} \mathrm{O}^{32} \mathrm{~S}_{2}^{+}: \mathrm{m} / \mathrm{z} 487.0986$.

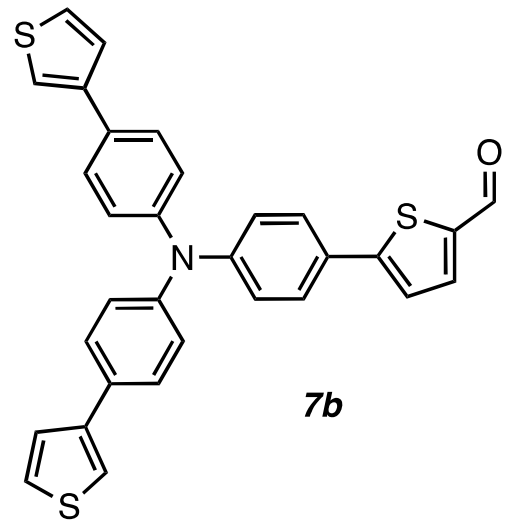

Synthesis of $\mathbf{7 b}$ : Under an atmosphere of $\mathrm{N}_{2}, \mathbf{2} \boldsymbol{b}(250 \mathrm{mg}, 0.49 \mathrm{mmol})$ and $\boldsymbol{B}$ (145 $\left.\mathrm{mg}, 1.13 \mathrm{mmol}\right)$ were dissolved in $55 \mathrm{~mL}$ of a mixture of THF: $\mathrm{H}_{2} \mathrm{O}$ 9:1 and the solution was sparged 10 min with $\mathrm{N}_{2}$. $\mathrm{K}_{2} \mathrm{CO}_{3}(677 \mathrm{mg}, 4.9 \mathrm{mmol})$ and $\mathrm{Pd}\left(\mathrm{PPh}_{3}\right)_{4}(113 \mathrm{mg}, 0.098 \mathrm{mmol})$ were added and the mixture was refluxed $12 \mathrm{~h}$. After being cooled to room temperature, $25 \mathrm{~mL}$ of $\mathrm{H}_{2} \mathrm{O}$ were added and the organic layer was separated. The aqueous layer was extracted with $\mathrm{Et}_{2} \mathrm{O}(3 \times 25 \mathrm{~mL})$ and the combined organic layers were dried over $\mathrm{MgSO}_{4}$, filtered and volatiles were removed in vacuo. The crude material was purified via column chromatography using $\mathrm{CH}_{2} \mathrm{Cl}_{2}$ as the eluent, affording the desired product as a yellow solid (113 mg, $44 \%)$. Mp 112-115 ${ }^{\circ} \mathrm{C}$; IR $\left(\mathrm{KBr}, \mathrm{cm}^{-1}\right)$ 1661. ${ }^{1} \mathrm{H} \mathrm{NMR}(400 \mathrm{MHz}$, $\left.\mathrm{CDCl}_{3}\right): \delta=9.86(\mathrm{~s}, 1 \mathrm{H}), 7.72\left(\mathrm{~d}, 1 \mathrm{H},{ }^{3} \mathrm{~J}_{\mathrm{HH}}=4.0 \mathrm{~Hz}\right), 7.56\left(\mathrm{~d}, 2 \mathrm{H},{ }^{3} \mathrm{~J}_{\mathrm{HH}}=8.6 \mathrm{~Hz}\right), 7.54\left(\mathrm{~d}, 4 \mathrm{H},{ }^{3} \mathrm{~J}_{\mathrm{HH}}=\right.$ $8.6 \mathrm{~Hz}), 7.40(\mathrm{~m}, 6 \mathrm{H}), 7.33(\mathrm{~d}, 1 \mathrm{H}), 7.19(\mathrm{~d}, 4 \mathrm{H}), 7.14(\mathrm{~d}, 2 \mathrm{H}) .{ }^{13} \mathrm{C}\left\{{ }^{1} \mathrm{H}\right\} \mathrm{NMR}\left(100 \mathrm{MHz}, \mathrm{CDCl}_{3}\right): \delta=$ 182.8, 154.6, 148.9, 146.0, 141.8, 141.6, 137.8, 131.7, 127.6, 127.5, 126.7, 126.5, 126.3, 125.4, 123.1, 123.0, 119.9. HRMS (DART): $\mathrm{m} / \mathrm{z} 520.0859\left[(\mathrm{M}+\mathrm{H})^{+}\right]$, calcd for ${ }^{12} \mathrm{C}_{31}{ }^{1} \mathrm{H}_{22}{ }^{14} \mathrm{~N}^{16} \mathrm{O}^{32} \mathrm{~S}_{3}{ }^{+}: \mathrm{m} / \mathrm{z}$ 520.0864 . 


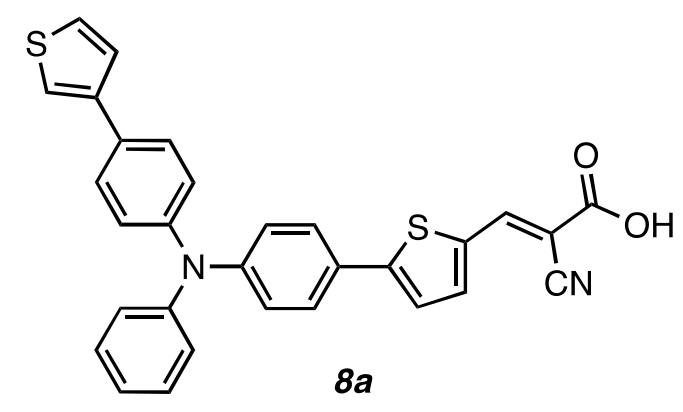

Synthesis of $8 a$ : $7 a(49 \mathrm{mg}, 0.11 \mathrm{mmol})$ was dissolved in $25 \mathrm{~mL}$ of $\mathrm{CHCl}_{3}$ and cyanoacetic acid (19 $\mathrm{mg}, 0.22 \mathrm{mmol}$ ) was added, followed by piperidine $(3 \mu \mathrm{L}, 0.03 \mathrm{mmol})$. The mixture was refluxed $12 \mathrm{~h}$ and after being cooled at room temperature, the organic layer was washed with $\mathrm{HCl} 1 \mathrm{~N}(3 \times 25 \mathrm{~mL})$. The organic layer was dried over $\mathrm{MgSO}_{4}$, filtered and volatiles were removed in vacuo. The crude product was recrystallized from hexanes: $\mathrm{CH}_{2} \mathrm{Cl}_{2} 3: 1$, affording the desired product as a dark red solid (52 mg, $94 \%)$. Mp 210-212 ${ }^{\circ} \mathrm{C}$; IR $\left(\mathrm{KBr}, \mathrm{cm}^{-1}\right)$ 2217, 1687. ${ }^{1} \mathrm{H}$ NMR $\left(400 \mathrm{MHz}\right.$, acetone- $\left.\mathrm{d}_{6}\right): \delta=8.42$ $(\mathrm{s}, 1 \mathrm{H}), 7.96\left(\mathrm{~d}, 1 \mathrm{H},{ }^{3} \mathrm{~J}_{\mathrm{HH}}=4.1 \mathrm{~Hz}\right), 7.72(\mathrm{~m}, 5 \mathrm{H}), 7.62(\mathrm{~d}, 1 \mathrm{H}), 7.56(\mathrm{~m}, 1 \mathrm{H}), 7.53(\mathrm{~m}, 1 \mathrm{H}), 7.39(\mathrm{~m}$, $2 \mathrm{H}), 7.18(\mathrm{~m}, 5 \mathrm{H}), 7.11\left(\mathrm{~d}, 2 \mathrm{H},{ }^{3} \mathrm{JHH}_{\mathrm{HH}}=8.8 \mathrm{~Hz}\right) \cdot{ }^{13} \mathrm{C}\left\{{ }^{1} \mathrm{H}\right\} \mathrm{NMR}\left(100 \mathrm{MHz}\right.$, acetone- $\left.\mathrm{d}_{6}\right): \delta=164.0,154.9$, $150.1,147.7,147.4,146.8,146.6,142.4,141.6,134.9,132.5,130.6,128.3,127.4,127.0,126.9$, 126.3, 126.2, 125.2, 124.6, 123.4, 123.1, 120.8, 117.0. HRMS (DART): $\mathrm{m} / \mathrm{z} 505.1056\left[(\mathrm{M}+\mathrm{H})^{+}\right]$, calcd for ${ }^{12} \mathrm{C}_{30}{ }^{1} \mathrm{H}_{21}{ }^{14} \mathrm{~N}_{2}{ }^{16} \mathrm{O}_{2}{ }^{32} \mathrm{~S}_{2}{ }^{+}: \mathrm{m} / \mathrm{z} 505.1044$.

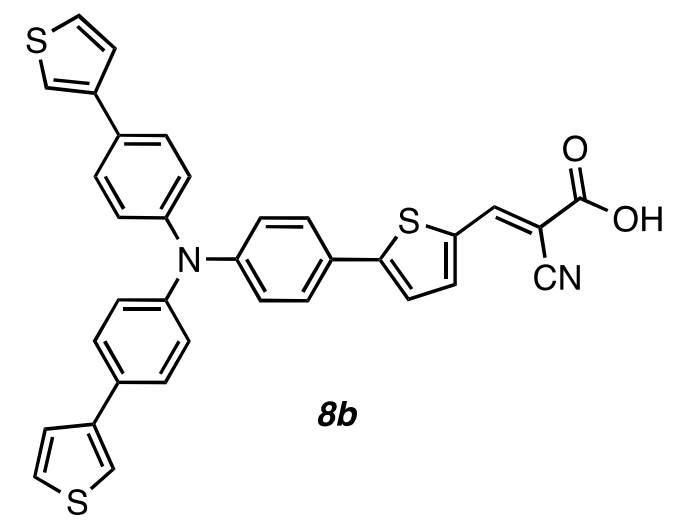

Synthesis of $8 \boldsymbol{b}: \mathbf{7 b}$ (53 $\mathrm{mg}, 0.10 \mathrm{mmol}$ ) was dissolved in $25 \mathrm{~mL}$ of $\mathrm{CHCl}_{3}$ and cyanoacetic acid (17 $\mathrm{mg}, 0.20 \mathrm{mmol}$ ) was added, followed by piperidine $(3 \mu \mathrm{L}, 0.03 \mathrm{mmol})$. The mixture was refluxed $12 \mathrm{~h}$ and after being cooled at room temperature, the organic layer was washed with $\mathrm{HCl} 1 \mathrm{~N}(3 \times 25 \mathrm{~mL})$. The organic layer was dried over $\mathrm{MgSO}_{4}$, filtered and volatiles were removed in vacuo. The crude product was recrystallized from hexanes: $\mathrm{CH}_{2} \mathrm{Cl}_{2} 3: 1$, affording the desired product as a dark red solid (68 mg, quantitative). Mp 164-168 ${ }^{\circ} \mathrm{C}$ (decomp); IR $\left(\mathrm{KBr}, \mathrm{cm}^{-1}\right)$ 2218, 1689. ${ }^{1} \mathrm{H}$ NMR $(400 \mathrm{MHz}$, $\left.\mathrm{CDCl}_{3}\right): \delta=8.32(\mathrm{~s}, 1 \mathrm{H}), 7.78\left(\mathrm{~d}, 1 \mathrm{H},{ }^{3} \mathrm{~J}_{\mathrm{HH}}=4.2 \mathrm{~Hz}\right), 7.58\left(\mathrm{~d}, 2 \mathrm{H},{ }^{3} \mathrm{~J}_{\mathrm{HH}}=8.8 \mathrm{~Hz}\right), 7.55\left(\mathrm{~d}, 4 \mathrm{H},{ }^{3} \mathrm{~J}_{\mathrm{HH}}=\right.$ 
8.6 Hz), $7.41(\mathrm{~m}, 6 \mathrm{H}), 7.36(\mathrm{~d}, 1 \mathrm{H}), 7.19(\mathrm{~d}, 4 \mathrm{H}), 7.14(\mathrm{~d}, 2 \mathrm{H}) .{ }^{13} \mathrm{C}\left\{{ }^{1} \mathrm{H}\right\} \mathrm{NMR}\left(100 \mathrm{MHz}, \mathrm{CDCl}_{3}\right): \delta=$ $149.3,147.9,145.8,141.8,140.4,140.4,137.4,134.0,131.9,127.7,127.6,126.5,126.3,126.1$, 125.6, 125.5, 123.6, 122.6, 120.0, $C=\mathrm{O}$ signal not detected. HRMS (DART): $\mathrm{m} / \mathrm{z} 587.0918\left[(\mathrm{M}+\mathrm{H})^{+}\right]$, calcd for ${ }^{12} \mathrm{C}_{34}{ }^{1} \mathrm{H}_{23}{ }^{14} \mathrm{~N}_{2}{ }^{16} \mathrm{O}_{2}{ }^{32} \mathrm{~S}_{3}{ }^{+}: \mathrm{m} / \mathrm{z} 587.0922$.

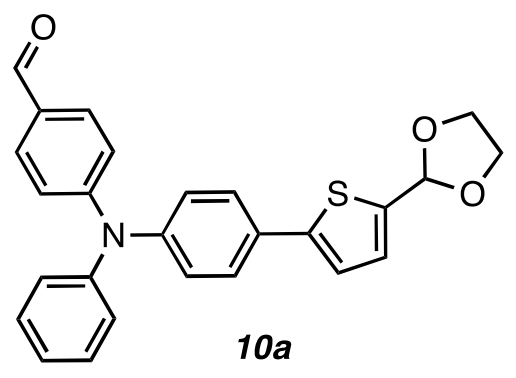

Synthesis of 10a: Under an atmosphere of $\mathrm{N}_{2}, 9 a(700 \mathrm{~g}, 2.0 \mathrm{mmol})$ and $\boldsymbol{C}(846 \mathrm{mg}, 3.0 \mathrm{mmol})$ were dissolved in $70 \mathrm{~mL}$ of a mixture of THF: $\mathrm{H}_{2} \mathrm{O} 9: 1$ and the solution was sparged 10 min with $\mathrm{N}_{2} . \mathrm{K}_{2} \mathrm{CO}_{3}$ $(1.27 \mathrm{~g}, 10.0 \mathrm{mmol})$ and $\mathrm{Pd}\left(\mathrm{PPh}_{3}\right)_{4}(208 \mathrm{mg}, 0.20 \mathrm{mmol})$ were added and the mixture was refluxed 12 h. After being cooled to room temperature, $50 \mathrm{~mL}$ of $\mathrm{H}_{2} \mathrm{O}$ were added and the organic layer was separated. The aqueous layer was extracted with $\mathrm{Et}_{2} \mathrm{O}(3 \times 50 \mathrm{~mL})$ and the combined organic layers were dried over $\mathrm{MgSO}_{4}$, filtered and volatiles were removed in vacuo. The crude material was purified via column chromatography using $\mathrm{CH}_{2} \mathrm{Cl}_{2}$ as the eluent, affording the desired product as a yellow oil (455 mg, $53 \%$ ), which was used as is. IR $\left(\mathrm{KBr}, \mathrm{cm}^{-1}\right)$ 1686. ${ }^{1} \mathrm{H} \mathrm{NMR}\left(400 \mathrm{MHz}, \mathrm{CDCl}_{3}\right): \delta=9.83$ (s, $1 \mathrm{H}), 7.70\left(\mathrm{~d}, 2 \mathrm{H},{ }^{3} \mathrm{~J}_{\mathrm{HH}}=8.4 \mathrm{~Hz}\right), 7.53\left(\mathrm{~d}, 2 \mathrm{H},{ }^{3} \mathrm{~J}_{\mathrm{HH}}=8.8 \mathrm{~Hz}\right), 7.36(\mathrm{~m}, 2 \mathrm{H}), 7.16(\mathrm{~m}, 7 \mathrm{H}), 7.06(\mathrm{~m}, 2 \mathrm{H})$, $6.09(\mathrm{~s}, 1 \mathrm{H}), 4.10(\mathrm{~m}, 4 \mathrm{H}) .{ }^{13} \mathrm{C}\left\{{ }^{1} \mathrm{H}\right\} \mathrm{NMR}\left(100 \mathrm{MHz}, \mathrm{CDCl}_{3}\right): \delta=190.6,153.2,146.1,145.8,144.7$, $141.0,131.5,130.0,129.7,127.4,127.2,127.1,126.5,126.2,125.5,122.6,120.1,100.5,65.4$. HRMS (DART): $m / z 428.1328\left[(\mathrm{M}+\mathrm{H})^{+}\right]$, calcd for ${ }^{12} \mathrm{C}_{26}{ }^{1} \mathrm{H}_{22}{ }^{14} \mathrm{~N}^{16} \mathrm{O}_{3}{ }^{32} \mathrm{~S}^{+}: \mathrm{m} / \mathrm{z} 428.1320$.<smiles>O=Cc1ccc(N(c2ccc(C=O)cc2)c2ccc(-c3ccc(C4OCCO4)s3)cc2)cc1</smiles> 
Synthesis of 10b: Under an atmosphere of $\mathrm{N}_{2}, 9 \boldsymbol{b}(1.0 \mathrm{~g}, 2.63 \mathrm{mmol})$ and $\boldsymbol{C}(1.11 \mathrm{~g}, 3.95 \mathrm{mmol})$ were dissolved in $90 \mathrm{~mL}$ of a mixture of THF: $\mathrm{H}_{2} \mathrm{O} 9: 1$ and the solution was sparged 10 min with $\mathrm{N}_{2} . \mathrm{K}_{2} \mathrm{CO}_{3}$ $(1.82 \mathrm{~g}, 13.2 \mathrm{mmol})$ and $\mathrm{Pd}\left(\mathrm{PPh}_{3}\right)_{4}(300 \mathrm{mg}, 0.26 \mathrm{mmol})$ were added and the mixture was refluxed 12 h. After being cooled to room temperature, $75 \mathrm{~mL}$ of $\mathrm{H}_{2} \mathrm{O}$ were added and the organic layer was separated. The aqueous layer was extracted with $\mathrm{Et}_{2} \mathrm{O}(3 \times 50 \mathrm{~mL})$ and the combined organic layers were dried over $\mathrm{MgSO}_{4}$, filtered and volatiles were removed in vacuo. The crude material was purified via column chromatography using $\mathrm{CH}_{2} \mathrm{Cl}_{2}$ as the eluent, affording the desired product as a yellow solid (1.114 g, $93 \%$ \%). Mp 84-89 ${ }^{\circ} \mathrm{C}$; IR $\left(\mathrm{KBr}, \mathrm{cm}^{-1}\right)$ 1693. ${ }^{1} \mathrm{H} \mathrm{NMR}\left(400 \mathrm{MHz}, \mathrm{CDCl}_{3}\right): \delta=9.91(\mathrm{~s}, 1 \mathrm{H})$, $7.80\left(\mathrm{~d}, 4 \mathrm{H},{ }^{3} \mathrm{~J}_{\mathrm{HH}}=8.6 \mathrm{~Hz}\right), 7.59\left(\mathrm{~d}, 2 \mathrm{H},{ }^{3} \mathrm{~J}_{\mathrm{HH}}=8.5 \mathrm{~Hz}\right), 7.22(\mathrm{~d}, 4 \mathrm{H}), 7.16(\mathrm{~m}, 4 \mathrm{H}), 6.10(\mathrm{~s}, 1 \mathrm{H}), 4.11$ $(\mathrm{m}, 4 \mathrm{H}) .{ }^{13} \mathrm{C}\left\{{ }^{1} \mathrm{H}\right\} \operatorname{NMR}\left(100 \mathrm{MHz}, \mathrm{CDCl}_{3}\right): \delta=190.6,151.9,145.1,141.5,132.3,131.7,131.5,127.6$, $127.5,127.1,123.7,123.2,123.1,100.4,65.5$. HRMS (DART): $\mathrm{m} / \mathrm{z} 456.1278\left[(\mathrm{M}+\mathrm{H})^{+}\right]$, calcd for ${ }^{12} \mathrm{C}_{27}{ }^{1} \mathrm{H}_{22}{ }^{14} \mathrm{~N}^{16} \mathrm{O}_{4}{ }^{32} \mathrm{~S}^{+}: \mathrm{m} / \mathrm{z} 456.1270$.

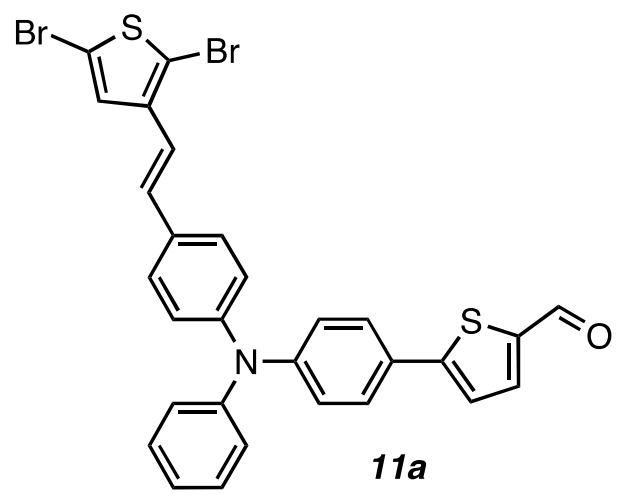

Synthesis of 11a: Under an atmosphere of $\mathrm{N}_{2}, 10 a(414 \mathrm{mg}, 0.97 \mathrm{mmol})$ and $\boldsymbol{D}(419 \mathrm{mg}, 1.07 \mathrm{mmol})$ were solubilized in $25 \mathrm{~mL}$ of dry THF and tBuOK $(130 \mathrm{mg}, 1.16 \mathrm{mmol}$ ) was added in one portion. The mixture was refluxed $24 \mathrm{~h}$ and cooled to room temperature. Volatiles were removed in vacuo and the crude product was purified via column chromatography using $\mathrm{CH}_{2} \mathrm{Cl}_{2}$ :hexanes $2: 1$ as the eluent, affording a mixture of the desired compound and its corresponding protected aldehyde. This mixture was then refluxed in $60 \mathrm{~mL}$ of glacial $\mathrm{AcOH}: \mathrm{H}_{2} \mathrm{O} 2: 1$ for $1 \mathrm{~h}$. After being cooled to room temperature, the solution was diluted with $150 \mathrm{~mL}$ of $\mathrm{H}_{2} \mathrm{O}$ and extracted using $\mathrm{CH}_{2} \mathrm{Cl}_{2}(3 \times 50 \mathrm{~mL})$. The combined organic fractions were dried over $\mathrm{MgSO}_{4}$, filtered and volatiles were removed in vacuo, affording the desired product as a yellow solid $(252 \mathrm{mg}, 39 \%)$. Mp 95-98 ${ }^{\circ} \mathrm{C}$; IR $\left(\mathrm{KBr}, \mathrm{cm}^{-1}\right)$ 1662. ${ }^{1} \mathrm{H}$ NMR $(400$ $\left.\mathrm{MHz}, \mathrm{CDCl}_{3}\right): \delta=9.86(\mathrm{~s}, 1 \mathrm{H}), 7.72\left(\mathrm{~d}, 1 \mathrm{H},{ }^{3} \mathrm{~J}_{\mathrm{HH}}=4.0 \mathrm{~Hz}\right), 7.54\left(\mathrm{~d}, 2 \mathrm{H},{ }^{3} \mathrm{~J}_{\mathrm{HH}}=8.7 \mathrm{~Hz}\right), 7.41(\mathrm{~d}, 2 \mathrm{H})$, $7.32(\mathrm{~m}, 3 \mathrm{H}), 7.21(\mathrm{~s}, 1 \mathrm{H}), 7.16(\mathrm{~d}, 2 \mathrm{H}), 7.11(\mathrm{~m}, 4 \mathrm{H}), 6.92\left(\mathrm{~d}, 1 \mathrm{H},{ }^{3} \mathrm{~J}_{\mathrm{HH}}=16.3 \mathrm{~Hz}\right), 6.86(\mathrm{~d}, 1 \mathrm{H})$. ${ }^{13} \mathrm{C}\left\{{ }^{1} \mathrm{H}\right\}$ NMR $\left(100 \mathrm{MHz}, \mathrm{CDCl}_{3}\right): \delta=182.8,154.5,148.8,147.1,146.8,141.7,139.4,137.8,131.9$, $130.7,129.8,127.5,127.4,126.9,125.6,124.6,124.5,123.2,123.2,119.1,112.0,109.8$. HRMS (DART): $m / z 619.9362\left[(\mathrm{M}+\mathrm{H})^{+}\right]$, calcd for ${ }^{12} \mathrm{C}_{29}{ }^{1} \mathrm{H}_{20}{ }^{79} \mathrm{Br}_{21}{ }^{14} \mathrm{~N}^{16} \mathrm{O}^{32} \mathrm{~S}_{2}{ }^{+}: m / z 619.9353$. 
<smiles>O=Cc1ccc(-c2ccc(N(c3ccc(/C=C/c4cc(Br)sc4Br)cc3)c3ccc(/C=C/c4cc(Br)sc4Br)cc3)cc2)s1</smiles>

Synthesis of 11b: Under an atmosphere of $\mathrm{N}_{2}, 10 \mathrm{~b}(439 \mathrm{mg}, 0.96 \mathrm{mmol})$ and $\boldsymbol{D}(808 \mathrm{mg}, 2.06 \mathrm{mmol})$ were solubilized in $30 \mathrm{~mL}$ of dry THF and tBuOK $(255 \mathrm{mg}, 2.27 \mathrm{mmol})$ was added in one portion. The mixture was refluxed $24 \mathrm{~h}$ and cooled to room temperature. Volatiles were removed in vacuo and the crude product was purified via column chromatography using $\mathrm{CH}_{2} \mathrm{Cl}_{2}$ :hexanes $3: 1$ as the eluent, affording a mixture of the desired compound and its corresponding protected aldehyde. This mixture was then refluxed in $60 \mathrm{~mL}$ of glacial $\mathrm{AcOH}: \mathrm{H}_{2} \mathrm{O} 2: 1$ for $1 \mathrm{~h}$. After being cooled to room temperature, the solution was diluted with $150 \mathrm{~mL}$ of $\mathrm{H}_{2} \mathrm{O}$ and extracted using $\mathrm{CH}_{2} \mathrm{Cl}_{2}(3 \times 50 \mathrm{~mL})$. The combined organic fractions were dried over $\mathrm{MgSO}_{4}$, filtered and volatiles were removed in vacuo, affording the desired product as an orange solid (158 mg, $19 \%)$. Mp 147-149 ${ }^{\circ} \mathrm{C}$; IR $\left(\mathrm{KBr}, \mathrm{cm}^{-1}\right)$ 1655. ${ }^{1} \mathrm{H}$ NMR $\left(400 \mathrm{MHz}, \mathrm{CDCl}_{3}\right): \delta=9.87(\mathrm{~s}, 1 \mathrm{H}), 7.72\left(\mathrm{~d}, 1 \mathrm{H},{ }^{3} \mathrm{~J}_{\mathrm{HH}}=4.0 \mathrm{~Hz}\right), 7.56\left(\mathrm{~d}, 2 \mathrm{H},{ }^{3} \mathrm{~J}_{\mathrm{HH}}=8.6 \mathrm{~Hz}\right), 7.43(\mathrm{~d}$, $\left.4 \mathrm{H},{ }^{3} \mathrm{~J}_{\mathrm{HH}}=8.6 \mathrm{~Hz}\right), 7.33(\mathrm{~d}, 1 \mathrm{H}), 7.21(\mathrm{~s}, 2 \mathrm{H}), 7.13(\mathrm{~m}, 6 \mathrm{H}), 6.93\left(\mathrm{~d}, 2 \mathrm{H},{ }^{3} \mathrm{~J}_{\mathrm{HH}}=16.2 \mathrm{~Hz}\right), 6.86(\mathrm{~d}, 2 \mathrm{H})$. ${ }^{13} \mathrm{C}\left\{{ }^{1} \mathrm{H}\right\}$ NMR $\left(100 \mathrm{MHz}, \mathrm{CDCl}_{3}\right): \delta=154.3,148.4,146.7,141.8,139.3,137.8,132.3,131.9,130.7$, 130.6, 130.2, 127.9, 127.6, 127.5, 124.9, 124.5, 123.8, 123.4, 121.5, 119.4, 112.0, 110.0. HRMS (DART): $m / z 887.7532\left[(\mathrm{M}+\mathrm{H})^{+}\right]$, calcd for ${ }^{12} \mathrm{C}_{35}{ }^{1} \mathrm{H}_{22}{ }^{79} \mathrm{Br}_{2}{ }^{81} \mathrm{Br}_{2}{ }^{14} \mathrm{~N}^{16} \mathrm{O}^{32} \mathrm{~S}_{3}{ }^{+}: m / z ~ 887.7556$. 


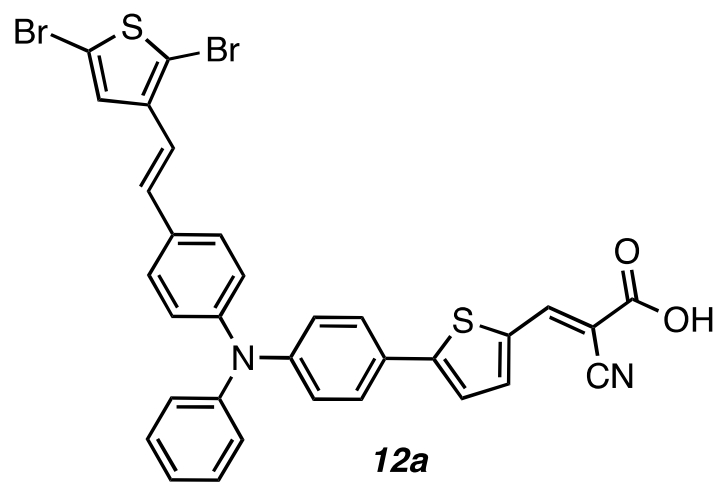

Synthesis of 12a: 11a (70 mg, $0.11 \mathrm{mmol})$ was dissolved in $25 \mathrm{~mL}$ of $\mathrm{CHCl}_{3}$ and cyanoacetic acid (19 $\mathrm{mg}, 0.23 \mathrm{mmol}$ ) was added, followed by piperidine $(3 \mu \mathrm{L}, 0.03 \mathrm{mmol})$. The mixture was refluxed $12 \mathrm{~h}$ and after being cooled at room temperature, the organic layer was washed with $\mathrm{HCl} 1 \mathrm{~N}(3 \times 25$ $\mathrm{mL}$ ). The organic layer was dried over $\mathrm{MgSO}_{4}$, filtered and volatiles were removed in vacuo. The crude product was recrystallized from hexanes: $\mathrm{CH}_{2} \mathrm{Cl}_{2} 3: 1$, affording the desired product as a dark red solid (59 mg, $78 \%$ ). Mp 211-215 ${ }^{\circ} \mathrm{C}$ (decomp.); IR $\left(\mathrm{KBr}, \mathrm{cm}^{-1}\right)$ 2217, 1688. ${ }^{1} \mathrm{H} \mathrm{NMR}(400 \mathrm{MHz}$, $\left.\mathrm{CDCl}_{3}\right): \delta=8.31(\mathrm{~s}, 1 \mathrm{H}), 7.77\left(\mathrm{~d}, 1 \mathrm{H},{ }^{3} \mathrm{~J}_{\mathrm{HH}}=3.9 \mathrm{~Hz}\right), 7.57\left(\mathrm{~d}, 2 \mathrm{H},{ }^{3} \mathrm{~J}_{\mathrm{HH}}=8.5 \mathrm{~Hz}\right), 7.42(\mathrm{~d}, 2 \mathrm{H}), 7.33(\mathrm{~m}$, $3 \mathrm{H}), 7.21(\mathrm{~s}, 1 \mathrm{H}), 7.16(\mathrm{~m}, 3 \mathrm{H}), 7.10(\mathrm{~m}, 4 \mathrm{H}), 6.92\left(\mathrm{~d}, 1 \mathrm{H},{ }^{3} \mathrm{~J}_{\mathrm{HH}}=16.2 \mathrm{~Hz}\right), 6.86(\mathrm{~d}, 1 \mathrm{H}) .{ }^{13} \mathrm{C}\left\{{ }^{1} \mathrm{H}\right\} \mathrm{NMR}$ $\left(100 \mathrm{MHz}, \mathrm{CDCl}_{3}\right): \delta=166.6,156.2,149.2,147.9,146.9,146.3,140.4,139.4,134.0,132.2,130.7$, $129.8,127.9,127.8,127.7,127.5,126.3,125.8,124.8,124.7,123.7,122.9,119.3,116.1,112.0$, 109.9. HRMS (DART): $m / z 642.9525\left[\left(\mathrm{M}+\mathrm{H}-\mathrm{CO}_{2}\right)^{+}\right]$, calcd for ${ }^{12} \mathrm{C}_{31}{ }^{1} \mathrm{H}_{21}{ }^{79} \mathrm{Br}_{2}{ }^{14} \mathrm{~N}_{2}{ }^{32} \mathrm{~S}_{2}{ }^{+}: \mathrm{m} / z 642.9513$.<smiles>N#C/C(=C\c1ccc(-c2ccc(N(c3ccc(/C=C/c4cc(Br)sc4Br)cc3)c3ccc(/C=C/c4cc(Br)sc4Br)cc3)cc2)s1)C(=O)O</smiles>

Synthesis of $12 b: 11 b(70 \mathrm{mg}, 0.08 \mathrm{mmol})$ was dissolved in $25 \mathrm{~mL}$ of $\mathrm{CHCl}_{3}$ and cyanoacetic acid (13 $\mathrm{mg}, 0.16 \mathrm{mmol}$ ) was added, followed by piperidine $(2 \mu \mathrm{L}, 0.02 \mathrm{mmol})$. The mixture was refluxed 
$12 \mathrm{~h}$ and after being cooled at room temperature, the organic layer was washed with $\mathrm{HCl} 1 \mathrm{~N}(3 \times 25$ $\mathrm{mL}$ ). The organic layer was dried over $\mathrm{MgSO}_{4}$, filtered and volatiles were removed in vacuo. The crude product was recrystallized from hexanes: $\mathrm{CH}_{2} \mathrm{Cl}_{2} 3: 1$, affording the desired product as a dark red solid (70 mg, $92 \%)$. Mp 183-184 ${ }^{\circ} \mathrm{C}$; IR $\left(\mathrm{KBr}, \mathrm{cm}^{-1}\right) 2217,1686 .{ }^{1} \mathrm{H} \mathrm{NMR}\left(400 \mathrm{MHz}, \mathrm{CDCl}_{3}\right): \delta=8.31$ $(\mathrm{s}, 1 \mathrm{H}), 7.77\left(\mathrm{~d}, 1 \mathrm{H},{ }^{3} \mathrm{~J}_{\mathrm{HH}}=4.0 \mathrm{~Hz}\right), 7.59\left(\mathrm{~d}, 2 \mathrm{H},{ }^{3} \mathrm{~J}_{\mathrm{HH}}=8.6 \mathrm{~Hz}\right), 7.44\left(\mathrm{~d}, 4 \mathrm{H},{ }^{3} \mathrm{~J}_{\mathrm{HH}}=8.5 \mathrm{~Hz}\right), 7.37(\mathrm{~d}$, $1 \mathrm{H}), 7.22(\mathrm{~s}, 2 \mathrm{H}), 7.13(\mathrm{~m}, 6 \mathrm{H}), 6.94\left(\mathrm{~d}, 2 \mathrm{H},{ }^{3} \mathrm{~J}_{\mathrm{HH}}=16.2 \mathrm{~Hz}\right), 6.87(\mathrm{~d}, 2 \mathrm{H}) .{ }^{13} \mathrm{C}\left\{{ }^{1} \mathrm{H}\right\} \mathrm{NMR}(100 \mathrm{MHz}$, $\left.\mathrm{CDCl}_{3}\right): \delta=155.9,148.8,147.9,147.8,146.5,140.4,139.3,134.2,132.6,130.6,127.0,127.8,127.5$, $126.8,125.1,123.8,123.5,119.5,116.1,112.1,110.0, C=O$ signal not detected. HRMS (DART): $\mathrm{m} / \mathrm{z}$ $910.7727\left[\left(\mathrm{M}+\mathrm{H}-\mathrm{CO}_{2}\right)^{+}\right]$, calcd for ${ }^{12} \mathrm{C}_{37} \mathrm{H}_{23}{ }^{79} \mathrm{Br}_{2}{ }^{81} \mathrm{Br}_{2}{ }^{14} \mathrm{~N}_{2}{ }^{32} \mathrm{~S}_{4}{ }^{+}: \mathrm{m} / \mathrm{z} 910.7716$.

\section{References}

1. Dienes, Y.; Durben, S.; Kárpáti, T.; Neumann, T.; Englert, U.; Nyulászi, L.; Baumgartner, T. Chem. Eur. J., 2007, 13, 7487.

2. Steinberger, S.; Mishra, A.; Reinold, E.; Mena-Osteritz, E.; Müller, H.; Uhrich, C.; Pfeiffer, M.; Bäuerle, P. J. Mater. Chem., 2012, 22, 2701.

3. Lu, K.; Sun, X.; Liu, Y.; Di, C.; Xi, H.; Yu, G.; Gao, X.; Du, C. J. Polym. Sci., Part A: Polym. Chem., 2009, 47, 1381.

4. Hagberg, D. P.; Marinado, T.; Karlsson, K. M.; Nonomura, K.; Qin, P.; Boschloo, G.; Brinck, T.; Hagfeldt, A.; Sun, L. J. Org. Chem., 2007, 72, 9550.

5. Zhang, L.; Liu, Y.; Wang, Z.; Liang, M.; Sun, Z.; Xue, S. Tetrahedron, 2010, 66, 3318.

6. Hagberg, D. P.; Jiang, X.; Gabrielsson, E.; Linder, M.; Marinado, T.; Brinck, T.; Hagfeldt, A.; Sun, L. J. Mater. Chem., 2009, 19, 7232.

7. Wang, H.; Li, Z.; Shao, P.; Liang, Y.; Wang, H.; Qin, J.; Gong, Q. New J. Chem., 2005, 29, 792.

8. Ghosh, K.; Masanta, G.; Chattopadhyay, A. P. Eur. J. Org. Chem., 2009, 4515. 


\section{Appendix B}

\section{Supporting information for}

Organic and Biomolecular Chemistry

The Synthesis and Study of Bichromic Triphenylamine-based Dyes Furnished with Bipodal Features for Lightharvesting Applications.

by

Omar K. Abdi, Hardeep S. Devgan, Eduardo Schott and Bryan D. Koivisto*

bryan.koivisto@ryerson.ca

$\underline{\text { Table of Contents }}$

Synthetic scheme S1.

p. S2

Figure S1 and S2

p.S3-S4

General considerations

p.S5

Experimental Procedures and Characterization

p. S6-S8

${ }^{1} \mathrm{H}$ and ${ }^{13} \mathrm{C}\left\{{ }^{1} \mathrm{H}\right\}$ NMR Spectra

p. S9-S23

References

P. S24 


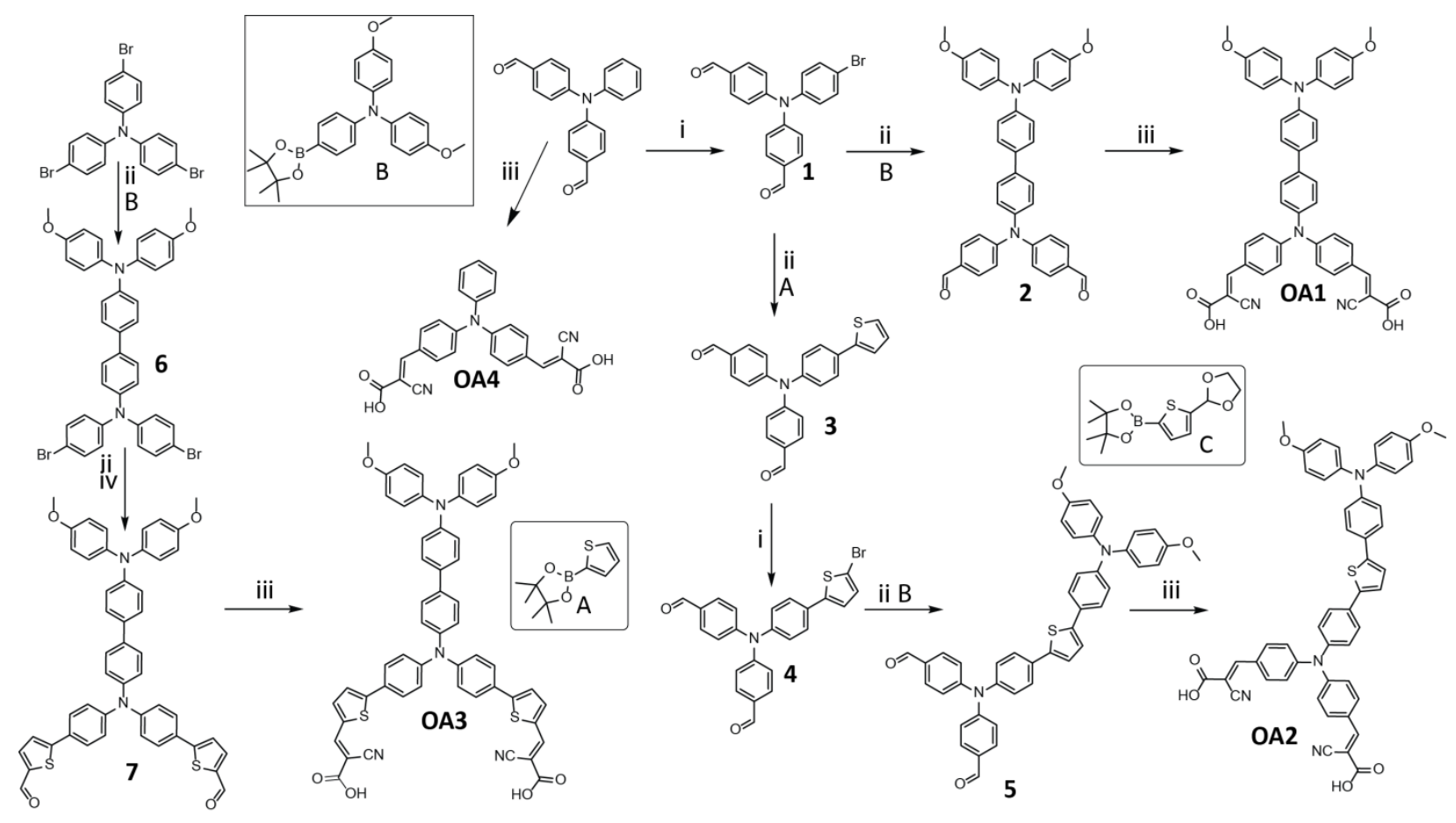

Scheme S1 Synthesis of dyes OA1, OA2, OA3 and OA4. Reaction conditions i) N-bromosuccinimide (1.10 eq), THF-EtOAc (1:1), 2 days; ii) $\mathrm{Pd}\left(\mathrm{PPh}_{3}\right)_{4}(0.10 \mathrm{eq}), \mathrm{NaOH}$ (8 eq), THF:water (9:1), reflux 12 hours; iii) cyanoacetic acid (4 eq), piperidine (0.25 eq), $\mathrm{CHCl}_{3}$, reflux 8 hours; iv) acetic acid: water (2:1), reflux 12 hours. 

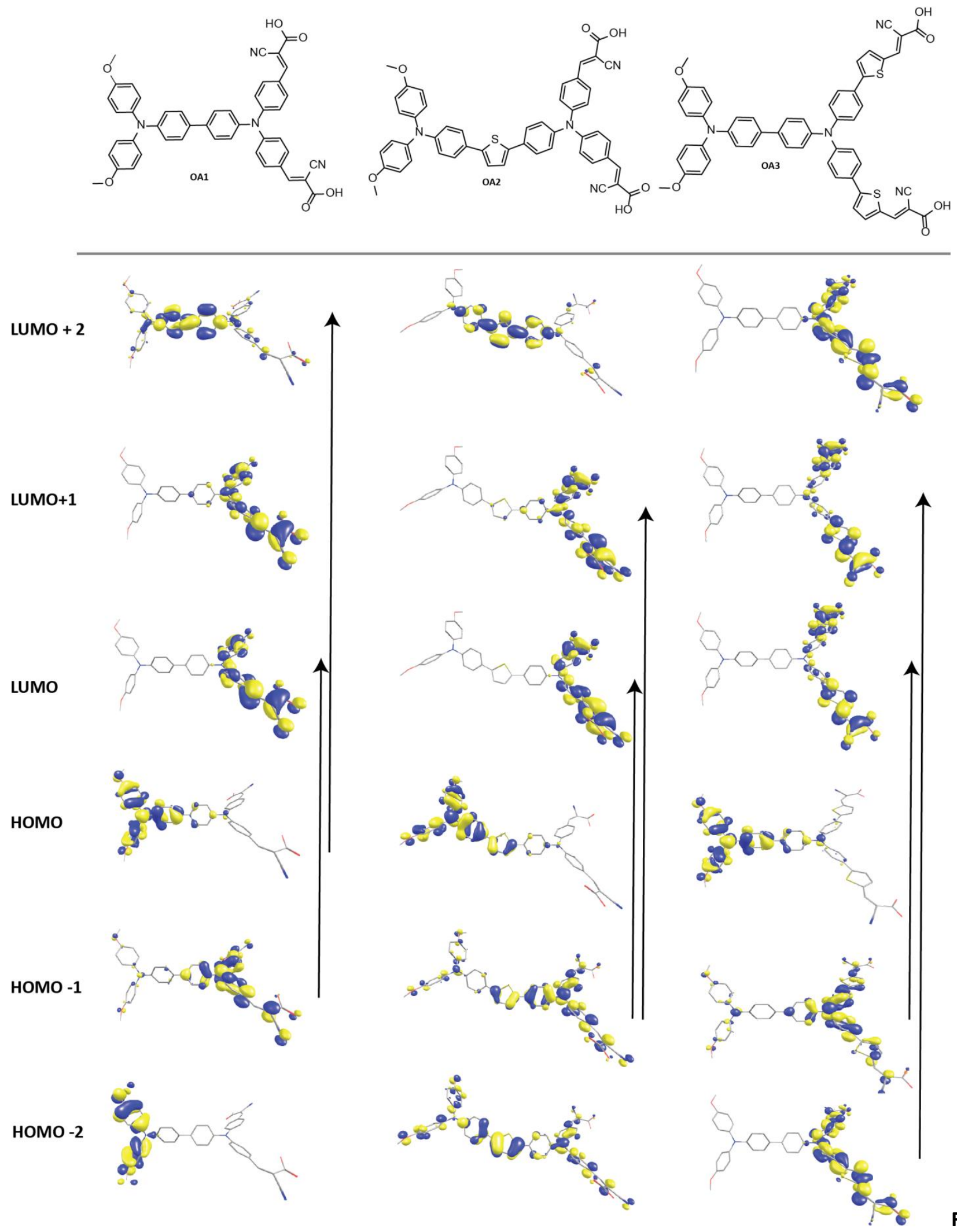

Fig

S1. Frontier molecular orbitals as predicted by DFT (B3LYP/6-31G) for OA1, OA2 and OA3 with inclusion of the dominant transitions as calculated by TD-DFT. 


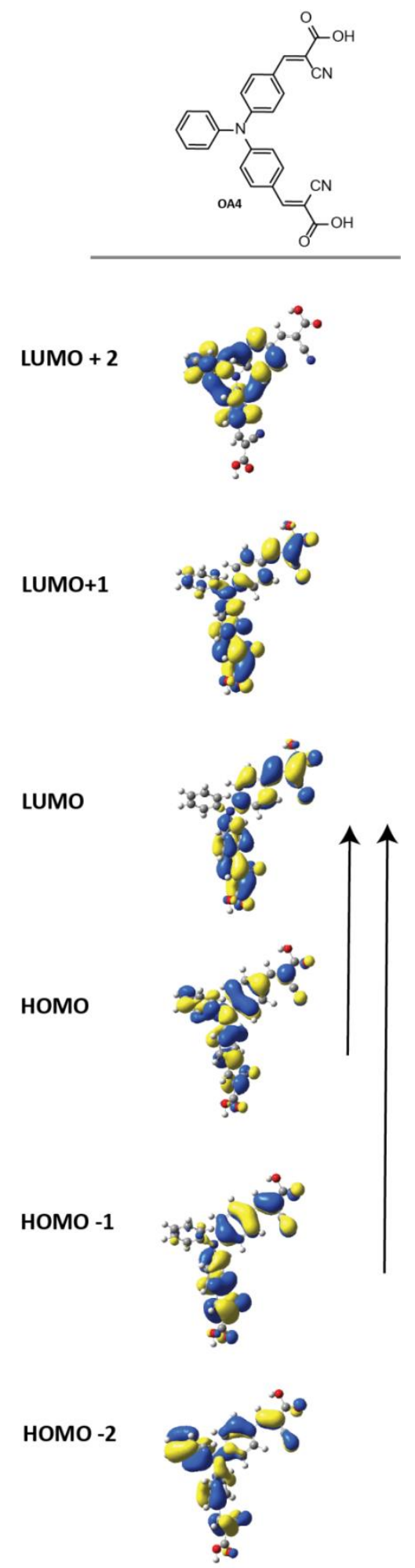

Fig S2. Frontier molecular orbitals as predicted by DFT (B3LYP /6-31G) for OA4 with inclusion of the dominant transitions as calculated by TD-DFT. 


\section{General Considerations}

All reagents were purchased from Aldrich. Purification by column chromatography was carried out using silica (Silicycle: ultrapure flash silica P60). Analytical thin-layer chromatography was performed on aluminum-backed sheets precoated with silica 60 F254 adsorbent $(0.25 \mathrm{~mm}$ thick; Silicycle) and visualized under UV light. RT refers to room temperature. Routine ${ }^{1} \mathrm{H},{ }^{13} \mathrm{C}$, spectra were recorded at 400 and $100 \mathrm{MHz}$, respectively, on a Bruker AV 400 instrument at ambient temperature. Chemical shifts $(\delta)$ are reported in parts per million (ppm) from low to high field and referenced to a residual non-deuterated solvent for ${ }^{1} \mathrm{H}$ and ${ }^{13} \mathrm{C}$ nuclei). Standard abbreviations indicating multiplicity are used as follows: $\mathrm{s}=$ singlet; $\mathrm{d}=$ doublet; $\mathrm{q}=$ quartet; $\mathrm{m}=\mathrm{multiplet}$; and $\mathrm{br}$ = broad. High resolution mass spectroscopy (HRMS) results were obtained from Queen University, Kingston Ontario. Electron impact (EI) mass spectrometry and Electrospray ionization (ESI) techniques were used for the ionization; time of flight (TOF) was used for analysis. UV-Vis data was taken using Cary Series Spectrophotometer from Agilent Technologies and dichloromethane (having the onset peak at $230 \mathrm{~nm}$ ) was used as a solvent. Infrared spectroscopy data was collected using the Cary 630 series FTIR spectrometer. The GAUSSIAN 09 computational package ${ }^{1}$ was used to perform ground-state geometry optimization calculations employing Becke's three-parameter hybrid exchange functional and the Lee-Yang-Parr non-local correlation functional B3LYP2 and 6-311G* basis set was used for all the atoms. Time-dependent density functional theory calculations were also performed using this methodology, and the first 200 singlet excited states were calculated. Calculations by the first-principles method were used to obtain accurate excitation energies and oscillator strengths. Solvent was modeled with the polarizable continuum model using acetonitrile as the solvent. 


\section{Synthetic Procedure}

Synthesis of 1: Under an atmosphere of $\mathrm{N}_{2}$, diformylTPA $(2.83 \mathrm{~g}, 9.41 \mathrm{mmol})$ was dissolved in $75 \mathrm{~mL}$ of THF:EtOAc (1:1) and $\mathrm{N}$-bromosuccinimide $(1.84 \mathrm{~g}, 10.4 \mathrm{mmol})$ was added in one portion. The flask was covered with $\mathrm{Al}$ foil and the mixture was stirred overnight. Volatiles were removed in vacuo and the crude was purified via column chromatography over silica using hexanes:EtOAc (3:2) as the eluent, affording the desired product as a yellow-green solid $(2.33 \mathrm{~g}, 65 \%) .{ }^{1} \mathrm{H}$ NMR $\left(400 \mathrm{MHz}\right.$, chloroform- $\left.\mathrm{d}_{3}\right)$ : $\delta=9.91(\mathrm{a}, \mathrm{s}, 2 \mathrm{H}), 7.79\left(\mathrm{~b}, \mathrm{~d}, 4 \mathrm{H},{ }^{3} \mathrm{~J}_{\mathrm{HH}}=8 \mathrm{~Hz}\right), 7.50\left(\mathrm{~d}, \mathrm{~d}, 2 \mathrm{H},{ }^{3} \mathrm{~J}_{\mathrm{HH}}=8 \mathrm{~Hz}\right), 7.18(\mathrm{c}, \mathrm{d}$, $\left.4 \mathrm{H},{ }^{3} \mathrm{~J}_{\mathrm{HH}}=8 \mathrm{~Hz}\right), 7.05\left(\mathrm{e}, \mathrm{d}, 2 \mathrm{H},{ }^{3} \mathrm{~J}_{\mathrm{HH}}=8 \mathrm{~Hz}\right)$.

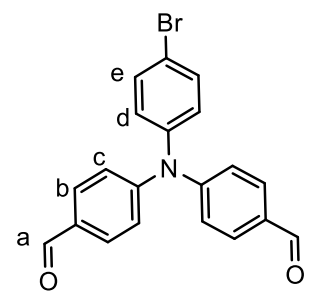<smiles>O=Cc1ccc(N(c2ccc(OI)cc2)c2ccc(-c3ccc(N(c4ccc(C=O)cc4)c4ccc(OCI)cc4)cc3)cc2)cc1</smiles>

Synthesis of 2: Under an atmosphere of $\mathrm{N}_{2}$, molecule $1(0.282 \mathrm{~g}, 0.74 \mathrm{mmol})$ was dissolved in $60 \mathrm{~mL}$ of THF: $\mathrm{H}_{2} \mathrm{O}(9: 1)$ and molecule $\mathbf{B}(0.42 \mathrm{~g}, 0.97 \mathrm{mmol})$ was added into the same flask. The flask was sparged for 15 minutes. The flask was charged with $\mathrm{Pd}\left(\mathrm{PPh}_{3}\right)_{4}(10 \mathrm{~mol} \%)$ followed by $\mathrm{NaOH}(8 \mathrm{eq})$ and refluxed overnight. Volatiles were removed in vacuo and an extraction with DCM was performed. The crude was purified via column chromatography over silica using using a gradient elution from DCM to hexanes:EtOAc (3:2) affording the desired product as a yellow solid $(0.251 \mathrm{~g}, 47 \%) .{ }^{1} \mathrm{H}$ NMR $\left(400 \mathrm{MHz}\right.$, chloroform- $\left.\mathrm{d}_{3}\right): \delta=9.90(\mathrm{a}, \mathrm{s}, 2 \mathrm{H}), 7.79\left(\mathrm{~b}, \mathrm{~d}, 4 \mathrm{H},{ }^{3} \mathrm{~J}_{\mathrm{HH}}=8 \mathrm{~Hz}\right), 7.56(\mathrm{e}$, $\left.\mathrm{d}, 2 \mathrm{H},{ }^{3} \mathrm{~J}_{\mathrm{HH}}=8 \mathrm{~Hz}\right), 7.40\left(\mathrm{f}, \mathrm{d}, 2 \mathrm{H},{ }^{3} \mathrm{~J}_{\mathrm{HH}}=8 \mathrm{~Hz}\right), 7.23\left(\mathrm{c}, \mathrm{d}, 4 \mathrm{H},{ }^{3} \mathrm{~J}_{\mathrm{HH}}=8 \mathrm{~Hz}\right), 7.18(\mathrm{~d}, 2$ $\left.\mathrm{H},{ }^{3} \mathrm{~J}_{\mathrm{HH}}=8 \mathrm{~Hz}\right), 7.09\left(\mathrm{~h}, \mathrm{~d}, 4 \mathrm{H},{ }^{3} \mathrm{~J}_{\mathrm{HH}}=8 \mathrm{~Hz}\right), 6.98\left(\mathrm{~g}, 2 \mathrm{H},{ }^{3} \mathrm{~J}_{\mathrm{HH}}=8 \mathrm{~Hz}\right), 6.85(\mathrm{i}, \mathrm{d}, 4 \mathrm{H}$, $\left.{ }^{3} \mathrm{~J}_{\mathrm{HH}}=8 \mathrm{~Hz}\right), 3.81(\mathrm{j}, \mathrm{s}, 6 \mathrm{H})$.

Synthesis of OA1: Molecule $2(0.233 \mathrm{~g}, 0.38 \mathrm{mmol})$ was dissolved in a 100 minimal amount of $\mathrm{CHCl}_{3}$ and cyanoacetic acid. Piperidine was then added. The mixture was refluxed overnight. The organic layer was washed with $\mathrm{HCl} 1 \mathrm{~N}$ and volatiles removed in vacuo. The crude was recrystallized in dcm:hexane (1:1) as a crimson red solid $(0.091 \mathrm{~g}, 39 \%)$; IR $\left(\mathrm{cm}^{-1}\right)$ 2229, 1720. ${ }^{1} \mathrm{H}$ NMR $(400 \mathrm{MHz}$, dimethylsulfoxide- $\left.\mathrm{d}_{6}\right): \delta 8.21(\mathrm{a}, \mathrm{s}, 2 \mathrm{H}), 8.01\left(\mathrm{~b}, \mathrm{~d}, 4 \mathrm{H},{ }^{3} \mathrm{~J}_{\mathrm{HH}}=8 \mathrm{~Hz}\right), 7.66(\mathrm{e}, \mathrm{d}, 2 \mathrm{H}$, $\left.{ }^{3} \mathrm{~J}_{\mathrm{HH}}=8 \mathrm{~Hz}\right), 7.51\left(\mathrm{f}, \mathrm{d}, 2 \mathrm{H},{ }^{3} \mathrm{~J}_{\mathrm{HH}}=8 \mathrm{~Hz}\right), 7.22\left(\mathrm{~d}, \mathrm{~d}, 2 \mathrm{H},{ }^{3} \mathrm{~J}_{\mathrm{HH}}=8 \mathrm{~Hz}\right), 7.19(\mathrm{c}, \mathrm{d}, 4 \mathrm{H}$, $\left.{ }^{3} \mathrm{~J}_{\mathrm{HH}}=8 \mathrm{~Hz}\right), 7.05(\mathrm{i}, \mathrm{d}, 4 \mathrm{H}), 6.92\left(\mathrm{~h}, \mathrm{~d}, 4 \mathrm{H},{ }^{3} \mathrm{~J}_{\mathrm{HH}}=8 \mathrm{~Hz}\right), 6.81\left(\mathrm{~g}, \mathrm{~d}, 2 \mathrm{H},{ }^{3} \mathrm{~J}_{\mathrm{HH}}=8\right.$ $\mathrm{Hz}) 3.75(\mathrm{~s}, 6 \mathrm{H}) .{ }^{13} \mathrm{C}\left\{{ }^{1} \mathrm{H}\right\} \mathrm{NMR}(100 \mathrm{MHz}$, dimethylsulfoxide-d6) $\delta=163.70,155.93$, $152.99,149.92,148.05,143.05,139.83,137.88,132.73,130.37,127.61,127.24$, 126.95, 125.99, 122.60, 119.09, 116.63, 115.01, 55.25.HRMS (ESI): $m / z$ 737.24194 $((\mathrm{M}-\mathrm{H}]-)$ calculated for $\mathrm{C}_{46} \mathrm{H}_{34} \mathrm{~N}_{4} \mathrm{O}_{6}: m / z$ 737.24056.

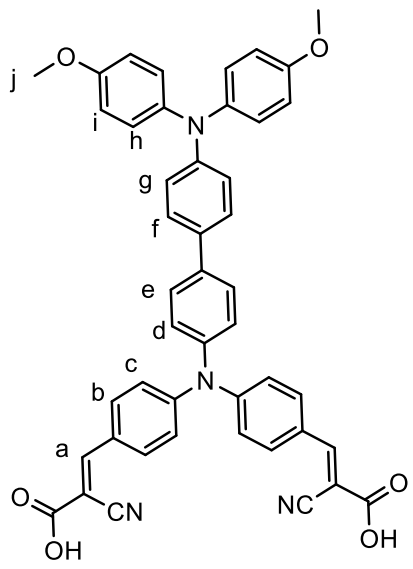<smiles>O=Cc1ccc(N(c2ccc(C=O)cc2)c2ccc(-c3cccs3)cc2)cc1</smiles>

Synthesis of 3: Under an atmosphere of $\mathrm{N}_{2}$, molecule A $(2.00 \mathrm{~g}, 5.26 \mathrm{mmol})$ was dissolved in $60 \mathrm{~mL}$ of THF: $\mathrm{H}_{2} \mathrm{O}(9: 1)$ and molecule 1 (1.105 g, $5.26 \mathrm{mmol}$ ) was added into the same flask. The flask was sparged for 15 minutes and then charged with $\mathrm{Pd}\left(\mathrm{PPh}_{3}\right)_{4}(10$ mol\%) followed by $\mathrm{NaOH}(8 \mathrm{eq})$ and refluxed overnight. Volatiles were removed in vacuo and an extraction with DCM was performed. The crude was purified via column chromatography over silica using hexanes:EtOAc (3:2) affording the desired product as a neon yellow, waxy oil.(1.0381 g, 51\%). ${ }^{1} \mathrm{H}$ NMR $\left(400 \mathrm{MHz}\right.$, chloroform- $\left.\mathrm{d}_{3}\right): \delta=9.91(\mathrm{a}, \mathrm{s}, 2$ $\mathrm{H}), 7.79\left(\mathrm{~b}, \mathrm{~d}, 4 \mathrm{H},{ }^{3} \mathrm{~J}_{\mathrm{HH}}=8 \mathrm{~Hz}\right), 7.62\left(\mathrm{e}, \mathrm{d}, 2 \mathrm{H},{ }^{3} \mathrm{~J}_{\mathrm{HH}}=8 \mathrm{~Hz}\right), 7.31\left(\mathrm{~d}, \mathrm{~d}, 2 \mathrm{H},{ }^{3} \mathrm{~J}_{\mathrm{HH}}=8 \mathrm{~Hz}\right)$, $7.22\left(\mathrm{c}, 4 \mathrm{H},{ }^{3} \mathrm{~J}_{\mathrm{HH}}=8 \mathrm{~Hz}\right), 7.17\left(\mathrm{f}+\mathrm{h}, \mathrm{d}, 2 \mathrm{H},{ }^{3} \mathrm{~J}_{\mathrm{HH}}=8 \mathrm{~Hz}\right), 7.10\left(\mathrm{~g}, \mathrm{t}, 1 \mathrm{H},{ }^{3} \mathrm{~J}_{\mathrm{HH}}=8 \mathrm{~Hz}\right)$. 
Synthesis of 4: Under an atmosphere of $\mathrm{N}_{2}$, Molecule $3(0.30 \mathrm{~g}, 0.79 \mathrm{mmol})$ was dissolved in $75 \mathrm{~mL}$ of THF:EtOAc (1:1) and $N$-bromosuccinimide $(0.16 \mathrm{~g}, 0.9 \mathrm{mmol})$ was added in one portion. The flask was covered with $\mathrm{Al}$ foil and the mixture was stirred overnight. Volatiles were removed in vacuo and the crude was purified via column chromatography over silica using hexanes:EtOAc (3:1) as the eluent, affording the desired product as a yellow waxy solid. $(0.201 \mathrm{~g}, 57 \%)$. ${ }^{1} \mathrm{H}$ NMR $\left(400 \mathrm{MHz}\right.$, chloroform- $\left.\mathrm{d}_{3}\right): \delta=9.91$ $(\mathrm{a}, \mathrm{s}, 2 \mathrm{H}), 7.79\left(\mathrm{~b}, \mathrm{~d}, 4 \mathrm{H},{ }^{3} \mathrm{~J}_{\mathrm{HH}}=8 \mathrm{~Hz}\right), 7.51\left(\mathrm{~d}, \mathrm{~d}, 2 \mathrm{H},{ }^{3} \mathrm{~J}_{\mathrm{HH}}=8 \mathrm{~Hz}\right), 7.22\left(\mathrm{c}, \mathrm{d}, 4 \mathrm{H},{ }^{3} \mathrm{~J}_{\mathrm{HH}}=8\right.$ $\mathrm{Hz}), 7.16\left(\mathrm{e}, \mathrm{d}, 2 \mathrm{H},{ }^{3} \mathrm{~J}_{\mathrm{HH}}=8 \mathrm{~Hz}\right), 7.04(\mathrm{f}+\mathrm{g}, \mathrm{s}, 2 \mathrm{H})$.

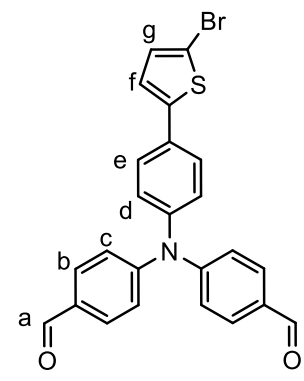

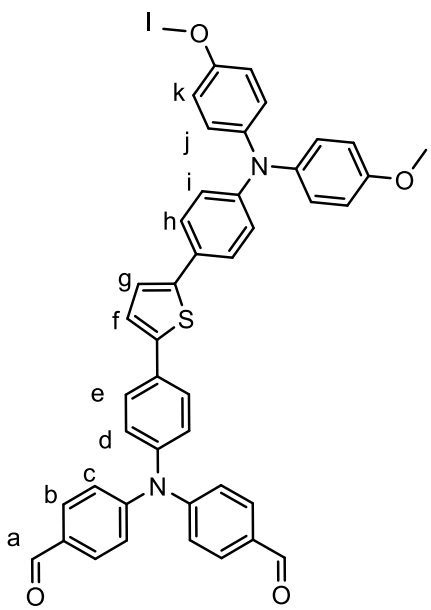

Synthesis of 5: Under an atmosphere of $\mathrm{N}_{2}$, molecule $4(.622 \mathrm{~g}, 1.34 \mathrm{mmol})$ was dissolved in $60 \mathrm{~mL}$ of THF: $\mathrm{H}_{2} \mathrm{O}(9: 1)$ and molecule $\mathbf{B}(0.638 \mathrm{~g}, 1.48 \mathrm{mmol})$ was added into the same flask. The flask was sparged for 15 minutes. The flask was charged with $\mathrm{Pd}\left(\mathrm{PPh}_{3}\right)_{4}(10 \mathrm{~mol} \%)$ followed by $\mathrm{NaOH}(8 \mathrm{eq})$ and refluxed overnight. Volatiles were removed in vacuo and an extraction with DCM was performed. The crude was purified via column chromatography over silica using hexanes:EtOAc (3:1) affording the desired product as a yellow solid. $(0.361 \mathrm{~g}$, $39 \%) .{ }^{1} \mathrm{H}$ NMR $\left(400 \mathrm{MHz}\right.$, chloroform- $\left.\mathrm{d}_{3}\right): \delta=9.90(\mathrm{a}, \mathrm{s}, 2 \mathrm{H}), 7.79\left(\mathrm{~b}, \mathrm{~d}, 4 \mathrm{H},{ }^{3} \mathrm{~J}_{\mathrm{HH}}=\right.$ $8 \mathrm{~Hz}), 7.61\left(\mathrm{f}+\mathrm{g}, \mathrm{d}, 2 \mathrm{H},{ }^{3} \mathrm{~J}_{\mathrm{HH}}=8 \mathrm{~Hz}\right), 7.43\left(\mathrm{~d}, \mathrm{~d}, 2 \mathrm{H},{ }^{3} \mathrm{~J}_{\mathrm{HH}}=8 \mathrm{~Hz}\right), 7.23(\mathrm{c}, \mathrm{d}, 4 \mathrm{H}$, $\left.{ }^{3} \mathrm{~J}_{\mathrm{HH}}=8 \mathrm{~Hz}\right), 7.16\left(\mathrm{~h}+\mathrm{e}, \mathrm{d}, 4 \mathrm{H},{ }^{3} \mathrm{~J}_{\mathrm{HH}}=8 \mathrm{~Hz}\right), 7.08(\mathrm{k}, \mathrm{d}, 4 \mathrm{H}), 6.92\left(\mathrm{i}, \mathrm{d}, 2 \mathrm{H},{ }^{3} \mathrm{~J}_{\mathrm{HH}}=\right.$ $8 \mathrm{~Hz}), 6.85\left(\mathrm{j}, \mathrm{d}, 4 \mathrm{H},{ }^{3} \mathrm{~J}_{\mathrm{HH}}=8 \mathrm{~Hz}\right), 3.81(\mathrm{~s}, 6 \mathrm{H}) .{ }^{13} \mathrm{C}\left\{{ }^{1} \mathrm{H}\right\} \mathrm{NMR}\left(100 \mathrm{MHz}, \mathrm{CDCl}_{3}\right)$ $\delta 190.62,156.21,151.91,148.58,144.58,144.42,140.88,140.67,132.52$, $131.59,131.49,127.24,126.86,126.40,126.20,124.42,123.08,122.80,120.50$, $114.89,55.63$.

Synthesis of OA2: Molecule 5 (0.434 g, $0.632 \mathrm{mmol})$ was dissolved in a in $100 \mathrm{ml}$ amount of $\mathrm{CHCl}_{3}$ and 2.5 equivalents cyanoacetic acid. Piperidine was then added. The mixture was refluxed overnight. The organic layer was washed with $\mathrm{HCl} 1 \mathrm{~N}$ and volatiles removed in vacuo. The crude was recrystallized in dcm:hexane (1:1) as a crimson red solid $(0.217 \mathrm{~g}, 50 \%)$. IR $\left(\mathrm{cm}^{-1}\right) 2223.819$, 1695.602. ${ }^{1} \mathrm{H}$ NMR $\left(400 \mathrm{MHz}\right.$, dimethylsulfoxide- $\left.\mathrm{d}_{6}\right): \delta=8.22(\mathrm{a}, \mathrm{s}, 2 \mathrm{H}), 8.01$ (b, d, $\left.4 \mathrm{H},{ }^{3} \mathrm{~J}_{\mathrm{HH}}=8 \mathrm{~Hz}\right), 7.70\left(\mathrm{e}, \mathrm{d}, 2 \mathrm{H},{ }^{3} \mathrm{~J}_{\mathrm{HH}}=8 \mathrm{~Hz}\right), 7.47(\mathrm{~h}+\mathrm{g}, \mathrm{m}, 3 \mathrm{H}), 7.32$ $\left(\mathrm{f}, \mathrm{d}, 1 \mathrm{H},{ }^{3} \mathrm{~J}_{\mathrm{HH}}=8 \mathrm{~Hz}\right), 7.19(\mathrm{c}+\mathrm{d}, \mathrm{m}, 6 \mathrm{H}), 7.03\left(\mathrm{k}, \mathrm{d}, 4 \mathrm{H},{ }^{3} \mathrm{~J}_{\mathrm{HH}}=8 \mathrm{~Hz}\right), 6.91(\mathrm{j}, \mathrm{d}$, $\left.4 \mathrm{H},{ }^{3} \mathrm{~J}_{\mathrm{HH}}=8 \mathrm{~Hz}\right), 6.77\left(\mathrm{l}, \mathrm{d}, 2 \mathrm{H},{ }^{3} \mathrm{~J}_{\mathrm{HH}}=8 \mathrm{~Hz}\right), 3.74(\mathrm{l}, \mathrm{s}, 6 \mathrm{H}) .{ }^{13} \mathrm{C}\left\{{ }^{1} \mathrm{H}\right\} \mathrm{NMR}(100$ $\left.\mathrm{MHz}, \mathrm{CDCl}_{3}\right) \delta 163.67,155.93,152.98,149.75,148.08,143.67,143.28$, $140.05,139.69,132.72,131.53,127.21,126.82,126.67,126.15,126.10$, $125.09,123.30,122.79,119.23,116.56,114.99,100.70,55.23,30.65 .$. HRMS (ESI): $m / z 819.22961((\mathrm{M}-\mathrm{H}]-)$ calculated for $\mathrm{C}_{50} \mathrm{H}_{36} \mathrm{~N}_{4} \mathrm{O}_{6} \mathrm{~S}: \mathrm{m} / z 819.22828$<smiles>COc1ccc(N(c2ccc(OCI)cc2)c2ccc(-c3ccc(N(c4ccc(Br)cc4)c4ccc(Br)cc4)cc3)cc2)cc1</smiles>

Synthesis of 6: Under an atmosphere of $\mathrm{N}_{2}$, para-

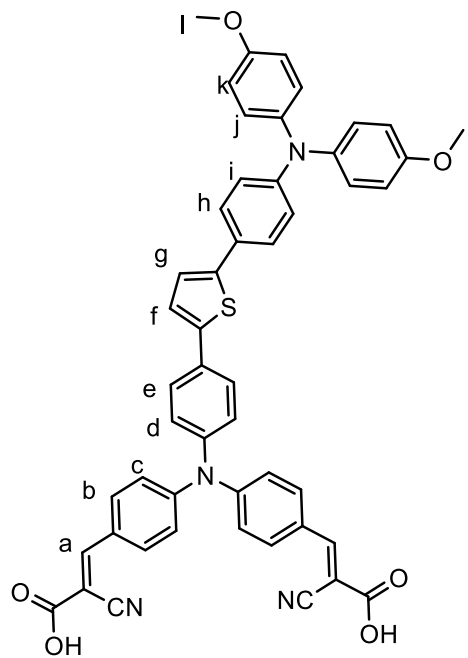
tribromo-triphenylamne $(1.5 \mathrm{~g}, 3.11 \mathrm{mmol})$ was dissolved in $150 \mathrm{~mL}$ of $\mathrm{THF}: \mathrm{H}_{2} \mathrm{O}(9: 1)$ and molecule B (1.475 g, $3.42 \mathrm{mmol})$ was added into the same flask. The flask was sparged for 15 minutes. The flask was charged with $\mathrm{Pd}\left(\mathrm{PPh}_{3}\right)_{4}(10 \mathrm{~mol} \%)$ followed by $\mathrm{NaOH}(8 \mathrm{eq})$ and refluxed overnight. Volatiles were removed in vacuo and an extraction with DCM was performed. The crude was purified via column chromatography over silica using hexanes:EtOAc (7:3) affording the desired product as a white solid. $(0.410 \mathrm{~g}$, $19 \%) .{ }^{1} \mathrm{H}$ NMR $\left(400 \mathrm{MHz}\right.$, chloroform- $\left.\mathrm{d}_{3}\right): \delta=7.44\left(\mathrm{~d}, \mathrm{~d}, 2 \mathrm{H},{ }^{3} \mathrm{~J}_{\mathrm{HH}}=8 \mathrm{~Hz}\right), 7.39-7.33$ $(\mathrm{a}+\mathrm{d}, \mathrm{m}, 6 \mathrm{H}), 7.08\left(\mathrm{~b}+\mathrm{c}, \mathrm{d}, 6 \mathrm{H},{ }^{3} \mathrm{~J}_{\mathrm{HH}}=8 \mathrm{~Hz}\right), 6.97\left(\mathrm{~h}, \mathrm{~d}, 4 \mathrm{H},{ }^{3} \mathrm{~J}_{\mathrm{HH}}=8 \mathrm{~Hz}\right), 6.84(\mathrm{f}+\mathrm{g}, \mathrm{d}$, $\left.6 \mathrm{H},{ }^{3} \mathrm{~J}_{\mathrm{HH}}=8 \mathrm{~Hz}\right), 3.80(\mathrm{l}, \mathrm{s}, 6 \mathrm{H})$. HRMS (ESI): $\mathrm{m} / \mathrm{z} 706.0657$ calculated for $\mathrm{C}_{48} \mathrm{H}_{36} \mathrm{~N}_{2} \mathrm{O}_{4} \mathrm{~S}_{2}: \mathrm{m} / 2706.07$. 
<smiles>COc1ccc(N(c2ccc(-c3ccc(N(c4ccc(-c5ccc(C=O)s5)cc4)c4ccc(-c5ccc(C=O)s5)cc4)cc3)cc2)c2ccc(OC)c(I)c2)cc1</smiles>

Synthesis of 7: Under an atmosphere of $\mathrm{N}_{2}, 6(.410 \mathrm{~g}, 0.58 \mathrm{mmol})$ was dissolved in $60 \mathrm{~mL}$ of THF: $\mathrm{H}_{2} \mathrm{O}(9: 1)$ and molecule c $(0.344 \mathrm{~g}, 1.22 \mathrm{mmol})$ was added into the same flask. The flask was sparged for 15 minutes. The flask was charged with $\mathrm{Pd}\left(\mathrm{PPh}_{3}\right)_{4}(10 \mathrm{~mol} \%)$ followed by $\mathrm{NaOH}(8 \mathrm{eq})$ and refluxed overnight. Volatiles were removed in vacuo and an extraction with DCM was performed. The crude was purified via column chromatography over silica using hexanes:EtOAc (7:3) affording the desired product as a red solid.( $0.023 \mathrm{~g}, 5$ $\%) .{ }^{1} \mathrm{H}$ NMR $\left(400 \mathrm{MHz}\right.$, chloroform- $\left.\mathrm{d}_{3}\right): \delta=9.87(\mathrm{a}, \mathrm{s}, 2 \mathrm{H}), 7.72\left(\mathrm{~b}, \mathrm{~d}, 2 \mathrm{H},{ }^{3} \mathrm{~J}_{\mathrm{HH}}=\right.$ $8 \mathrm{~Hz}), 7.58\left(\mathrm{~d}, \mathrm{~d}, 4 \mathrm{H},{ }^{3} \mathrm{~J}_{\mathrm{HH}}=8 \mathrm{~Hz}\right), 7.51\left(\mathrm{c}, \mathrm{d}, 2 \mathrm{H},{ }^{3} \mathrm{~J}_{\mathrm{HH}}=8 \mathrm{~Hz}\right), 7.40(\mathrm{~g}, \mathrm{~d}, 2 \mathrm{H}$, $\left.{ }^{3} \mathrm{~J}_{\mathrm{HH}}=8 \mathrm{~Hz}\right), 7.34\left(\mathrm{~h}, \mathrm{~d}, 2 \mathrm{H},{ }^{3} \mathrm{~J}_{\mathrm{HH}}=8 \mathrm{~Hz}\right), 7.18\left(\mathrm{e}+\mathrm{f}, \mathrm{m}, 6 \mathrm{H},{ }^{3} \mathrm{~J}_{\mathrm{HH}}=8 \mathrm{~Hz}\right), 7.09(\mathrm{j}$, $\left.\mathrm{d}, 4 \mathrm{H},{ }^{3} \mathrm{~J}_{\mathrm{HH}}=8 \mathrm{~Hz}\right), 6.99\left(\mathrm{i}, \mathrm{d}, 2 \mathrm{H},{ }^{3} \mathrm{~J}_{\mathrm{HH}}=8 \mathrm{~Hz}\right), 6.85\left(\mathrm{k}, \mathrm{d}, 4 \mathrm{H},{ }^{3} \mathrm{~J}_{\mathrm{HH}}=8 \mathrm{~Hz}\right)$, $3.81(\mathrm{I}, \mathrm{s}, 6 \mathrm{H})$. HRMS (ESI): $\mathrm{m} / \mathrm{z} 768.211110$ calculated for $\mathrm{C}_{48} \mathrm{H}_{36} \mathrm{~N}_{2} \mathrm{O}_{4} \mathrm{~S}_{2}: \mathrm{m} / \mathrm{z}$ 768.21 .

Synthesis of OA3: Molecule $7(0.027 \mathrm{~g}, 0.03 \mathrm{mmol})$ was dissolved in $50 \mathrm{ml}$ $\mathrm{CHCl}_{3}$ and 2.5 equivalents of cyanoacetic acid. 3 drops of piperidine was then added. The mixture was refluxed and monitored via thin layer chromatography. The organic layer was washed with $\mathrm{HCl} 1 \mathrm{~N}$ and volatiles removed in vacuo. The crude was recrystallized in $\mathrm{dcm}$ :hexane (1:1) as a crimson red solid ( 0.023 g, 84\%). IR $\left(\mathrm{cm}^{-1}\right)$ 2222.788, 1649.201. ${ }^{1} \mathrm{H}$ NMR $(400 \mathrm{MHz}$, dimethylsulfoxide$\left.\mathrm{d}_{6}\right): \delta=8.44(\mathrm{a}, \mathrm{s}, 2), 8.00(\mathrm{~b}, \mathrm{~m}, 2 \mathrm{H}), 7.81\left(\mathrm{~d}, \mathrm{~d}, 4 \mathrm{H},{ }^{3} \mathrm{~J}_{\mathrm{HH}}=8 \mathrm{~Hz}\right), 7.67(\mathrm{e}, \mathrm{d}, 4$ $\left.\mathrm{H},{ }^{3} \mathrm{~J}_{\mathrm{HH}}=8 \mathrm{~Hz}\right), 7.54\left(\mathrm{c}, \mathrm{d}, 2 \mathrm{H},{ }^{3} \mathrm{~J}_{\mathrm{HH}}=8 \mathrm{~Hz}\right), 7.30-7.23\left(\mathrm{~g}+\mathrm{h}, \mathrm{m}, 6 \mathrm{H},{ }^{3} \mathrm{~J}_{\mathrm{HH}}=8\right.$ $\mathrm{Hz}), 7.10\left(\mathrm{k}, \mathrm{d}, 4 \mathrm{H},{ }^{3} \mathrm{~J}_{\mathrm{HH}}=8 \mathrm{~Hz}\right), 6.93\left(\mathrm{j}+\mathrm{i}, \mathrm{d}, 6 \mathrm{H},{ }^{3} \mathrm{~J}_{\mathrm{HH}}=8 \mathrm{~Hz}\right), 3.80(\mathrm{l}, \mathrm{s}, 6 \mathrm{H})$. ${ }^{13} \mathrm{C}\left\{{ }^{1} \mathrm{H}\right\}$ NMR $\left(100 \mathrm{MHz}\right.$, dimethylsulfoxide- $\left.\mathrm{d}_{6}\right) \delta 200.01,155.86,147.16,147.16$, $144.51,144.51,139.98,135.90,135.90,135.13,135.13,130.85,130.85$, $129.30,127.26,127.03,126.80,125.44,125.43,123.95,123.73,119.46$, $118.80,115.02,55.29,43.68,30.71,22.20,21.72$.

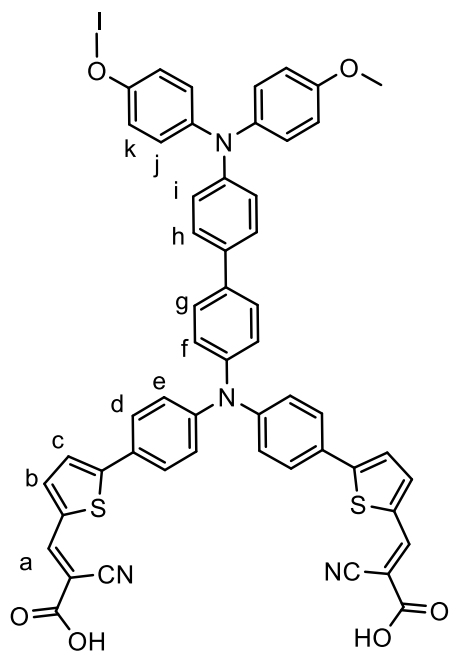

Synthesis of OA4: diformyITPA $(0.950 \mathrm{~g}, 3.15 \mathrm{mmol})$ was dissolved in $50 \mathrm{ml}$ of $\mathrm{CHCl}_{3}$ and cyanoacetic<smiles>N#C/C(=C\c1ccc(N(c2ccc(I)cc2)c2ccc(/C=C(\C#N)C(=O)O)cc2)cc1)C(=O)O</smiles>
acid. 3 drops of piperidine was then added. The mixture was refluxed and monitored via thin layer chromatography. The organic layer was washed with $\mathrm{HCl}$ $1 \mathrm{~N}$ and volatiles removed in vacuo. The crude was recrystallized in $\mathrm{dcm}$ :hexane (1:1) as a dark orange solid ( $0.026 \mathrm{~g}, 0.019 \%)$. IR $\left(\mathrm{cm}^{-1}\right) 2217.502,1699.994 .{ }^{1} \mathrm{H}$ NMR $\left(400 \mathrm{MHz}\right.$, dimethylsulfoxide- $\left.\mathrm{d}_{6}\right): \delta=8.22(\mathrm{a}, \mathrm{s}, 2), 8.01\left(\mathrm{~b}, \mathrm{~d}, 2 \mathrm{H},{ }^{3} \mathrm{~J}_{\mathrm{HH}}=8\right.$ $\mathrm{Hz}), 7.48\left(\mathrm{e}, \mathrm{t}, 2 \mathrm{H},{ }^{3} \mathrm{~J}_{\mathrm{HH}}=8 \mathrm{~Hz}\right), 7.33\left(\mathrm{f}, \mathrm{t}, 1 \mathrm{H},{ }^{3} \mathrm{~J}_{\mathrm{HH}}=8 \mathrm{~Hz}\right), 7.23\left(\mathrm{~d}, \mathrm{~d}, 2 \mathrm{H},{ }^{3} \mathrm{~J}_{\mathrm{HH}}=\right.$ $8 \mathrm{~Hz}), 7.16\left(\mathrm{c}, \mathrm{d}, 4 \mathrm{H},{ }^{3} \mathrm{~J}_{\mathrm{HH}}=8 \mathrm{~Hz}\right) \cdot{ }^{13} \mathrm{C}\left\{{ }^{1} \mathrm{H}\right\} \operatorname{NMR}(100 \mathrm{MHz}$, dimethylsulfoxide-d6) $\delta 163.95,154.21,152.60,150.28,133.76,132.19,132.15,129.22,126.18$, $126.10,123.50,123.45,121.89,121.84,116.94,116.80,100.75$. 


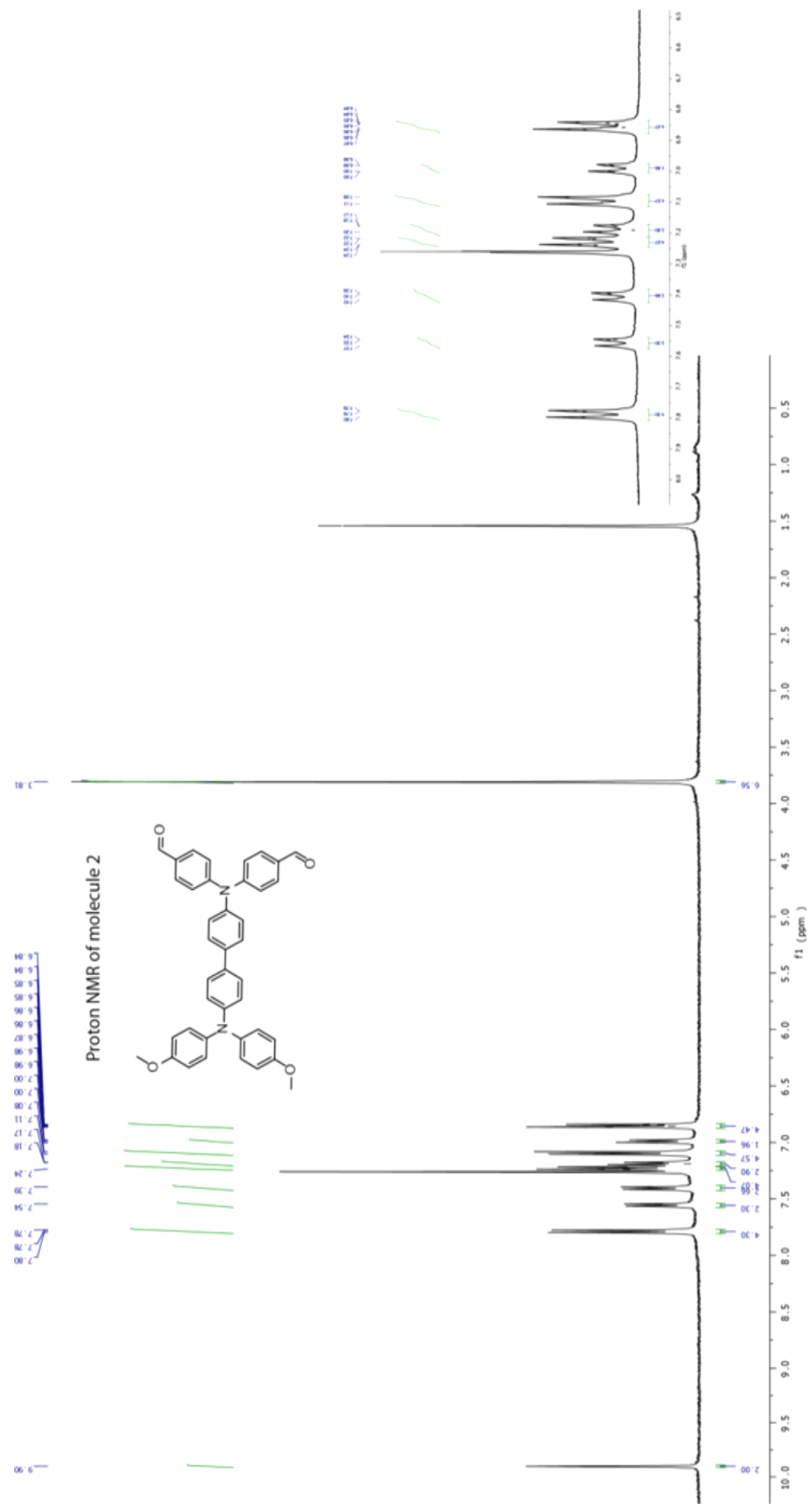




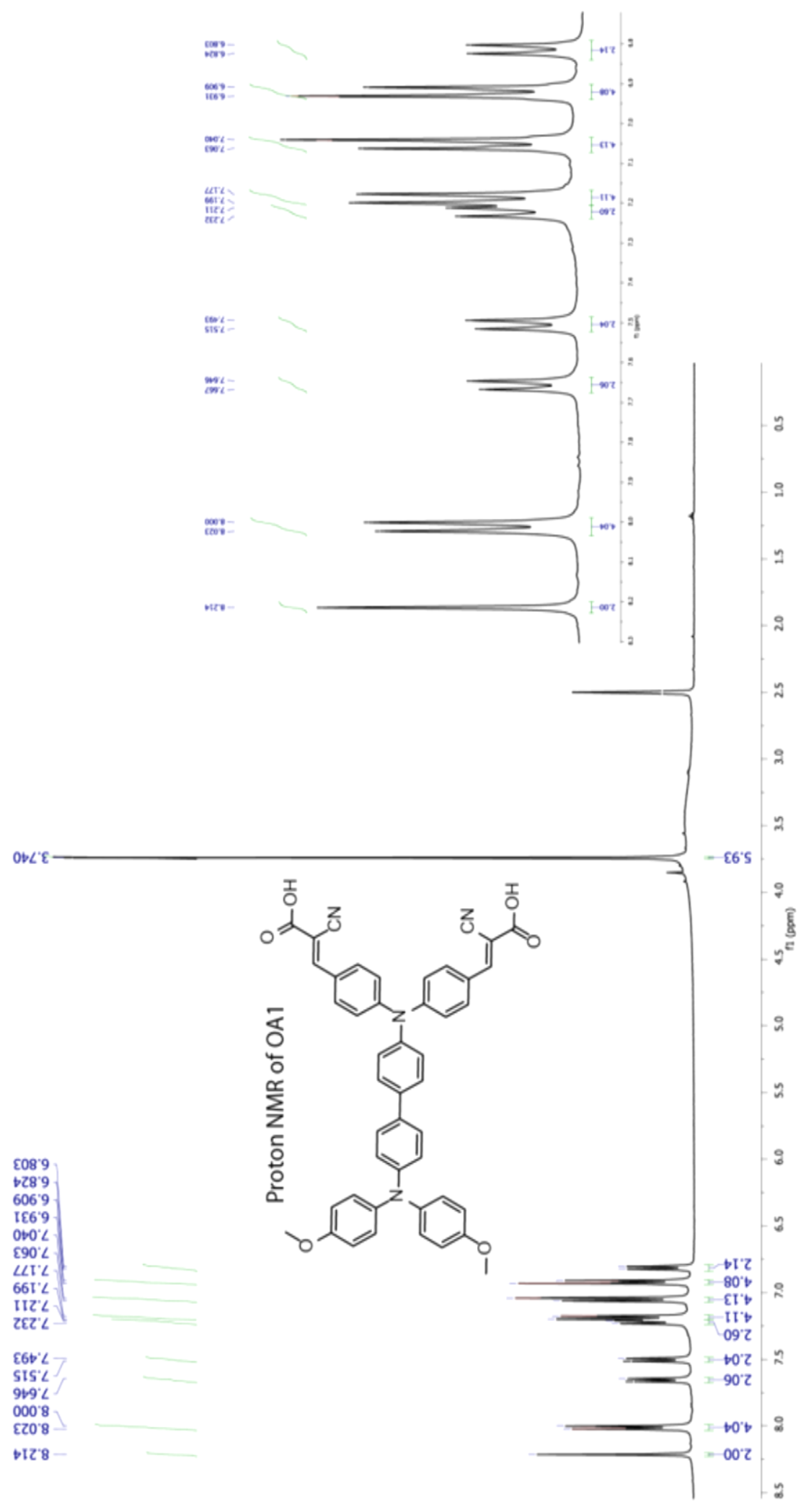




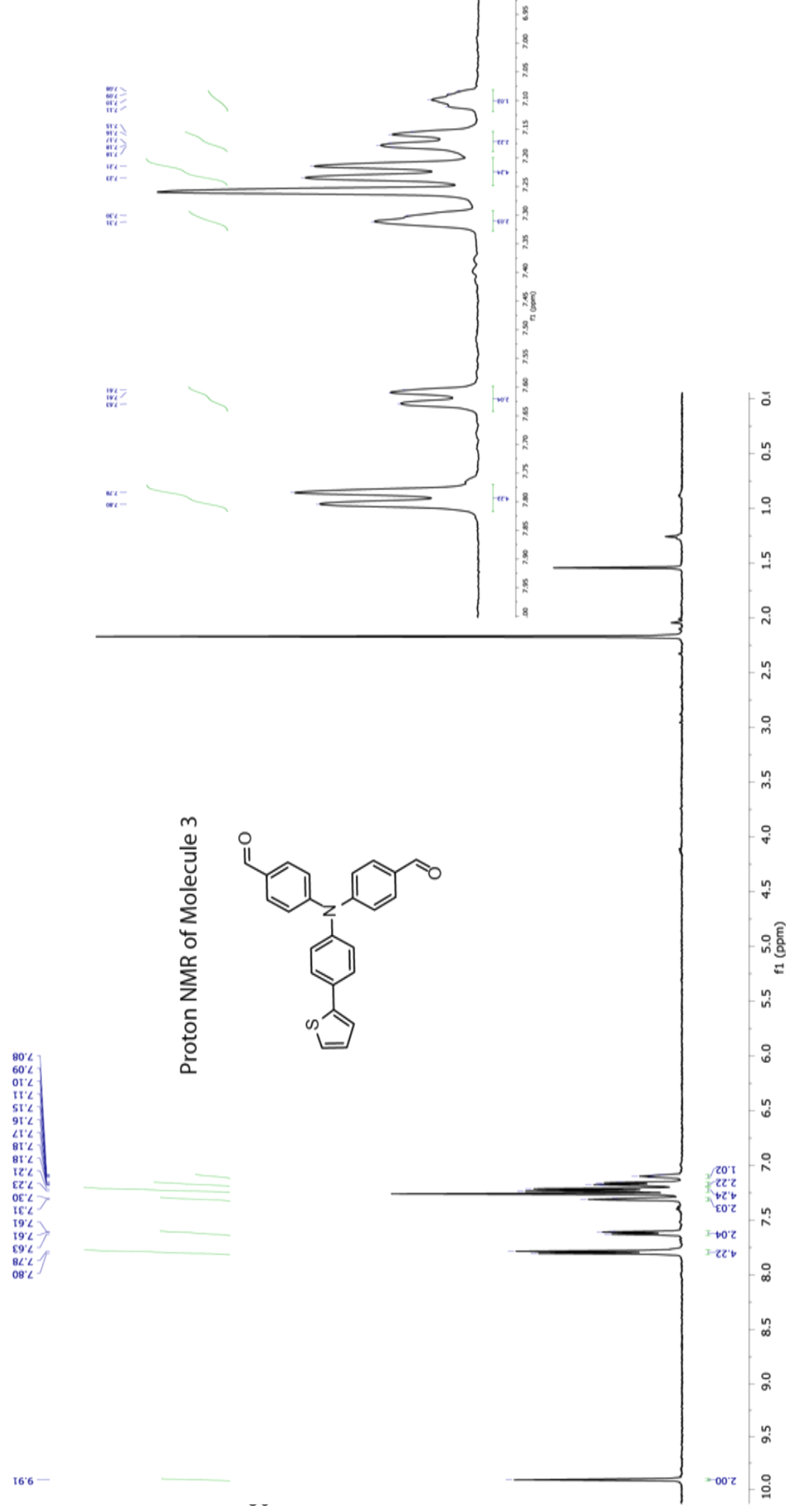




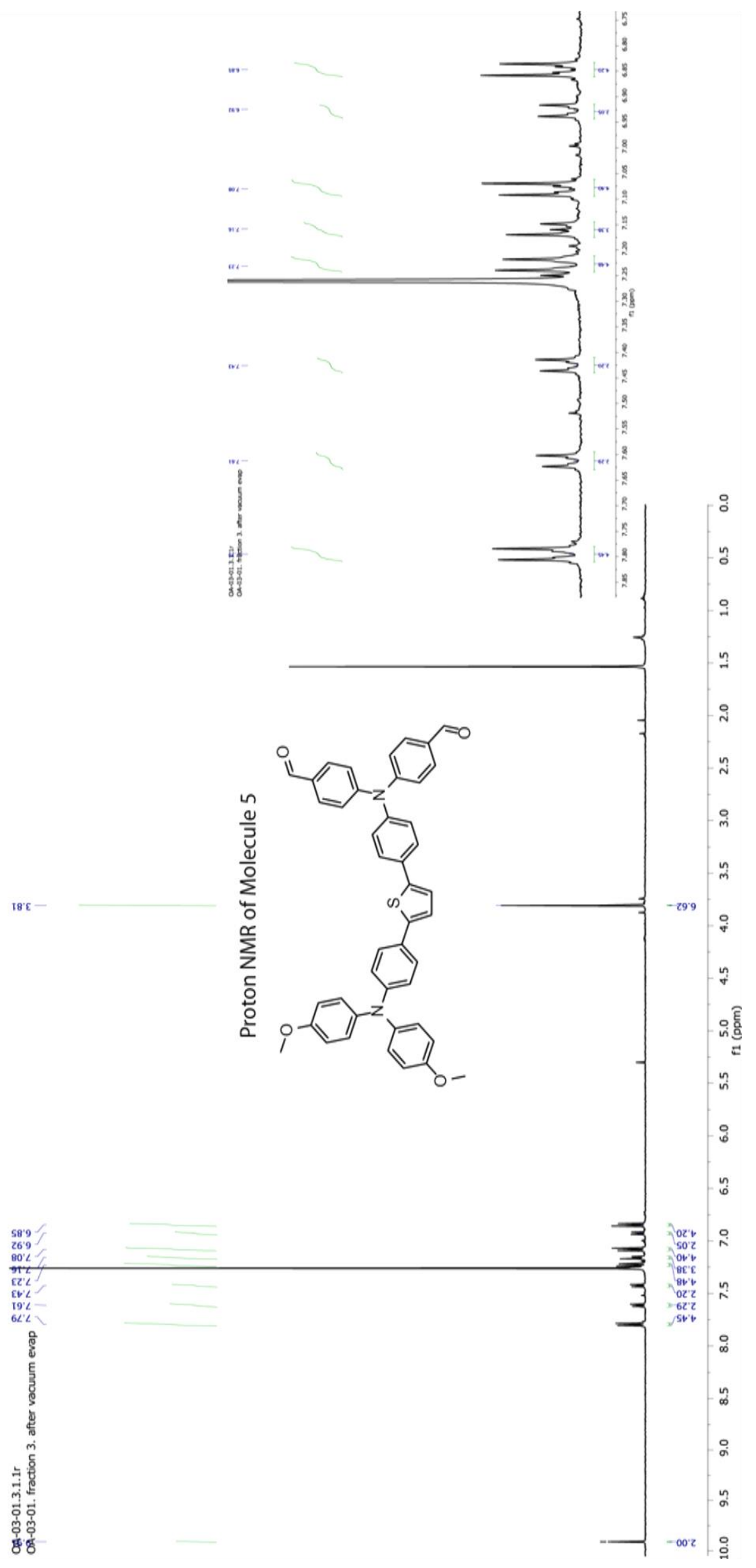




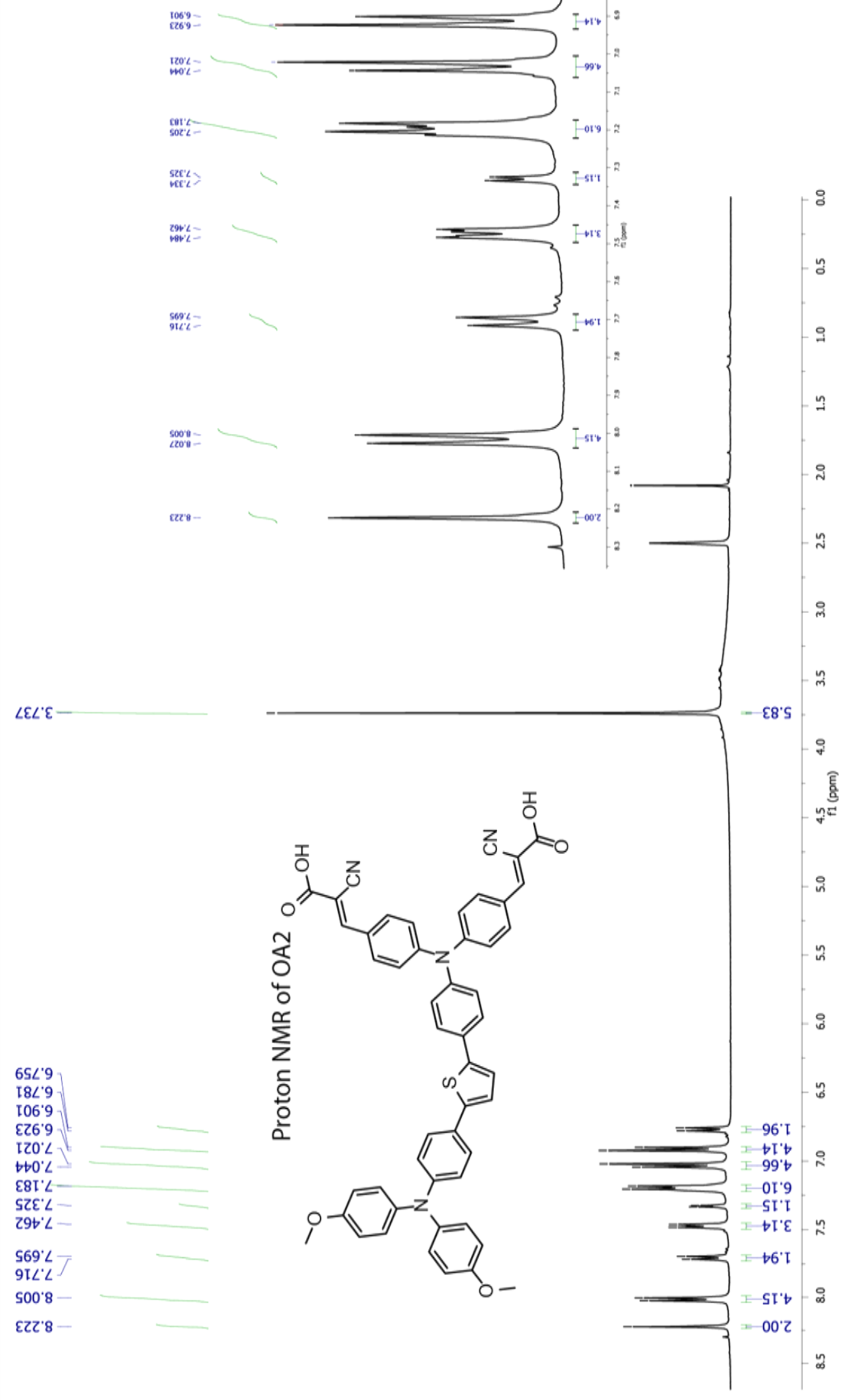




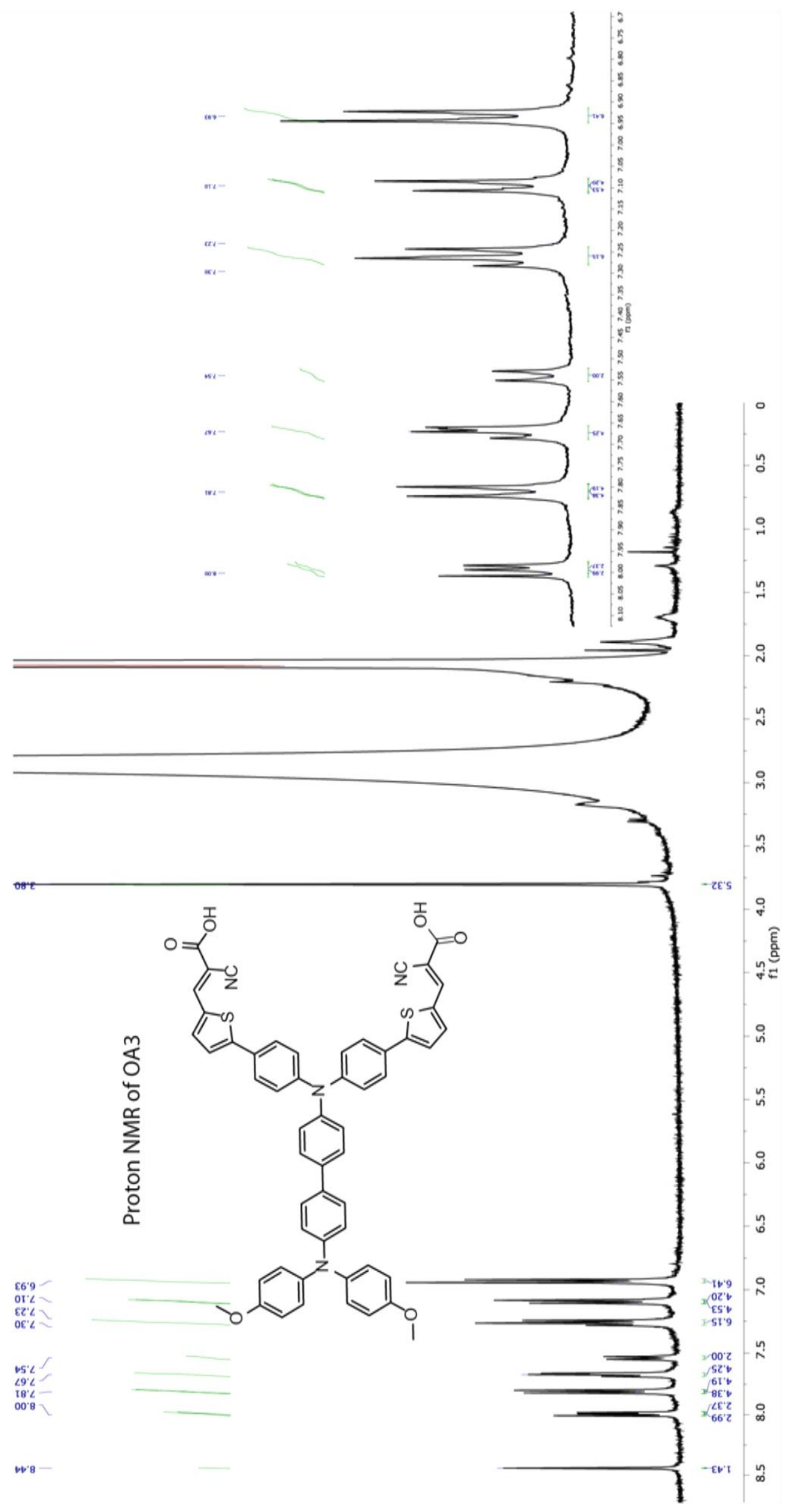




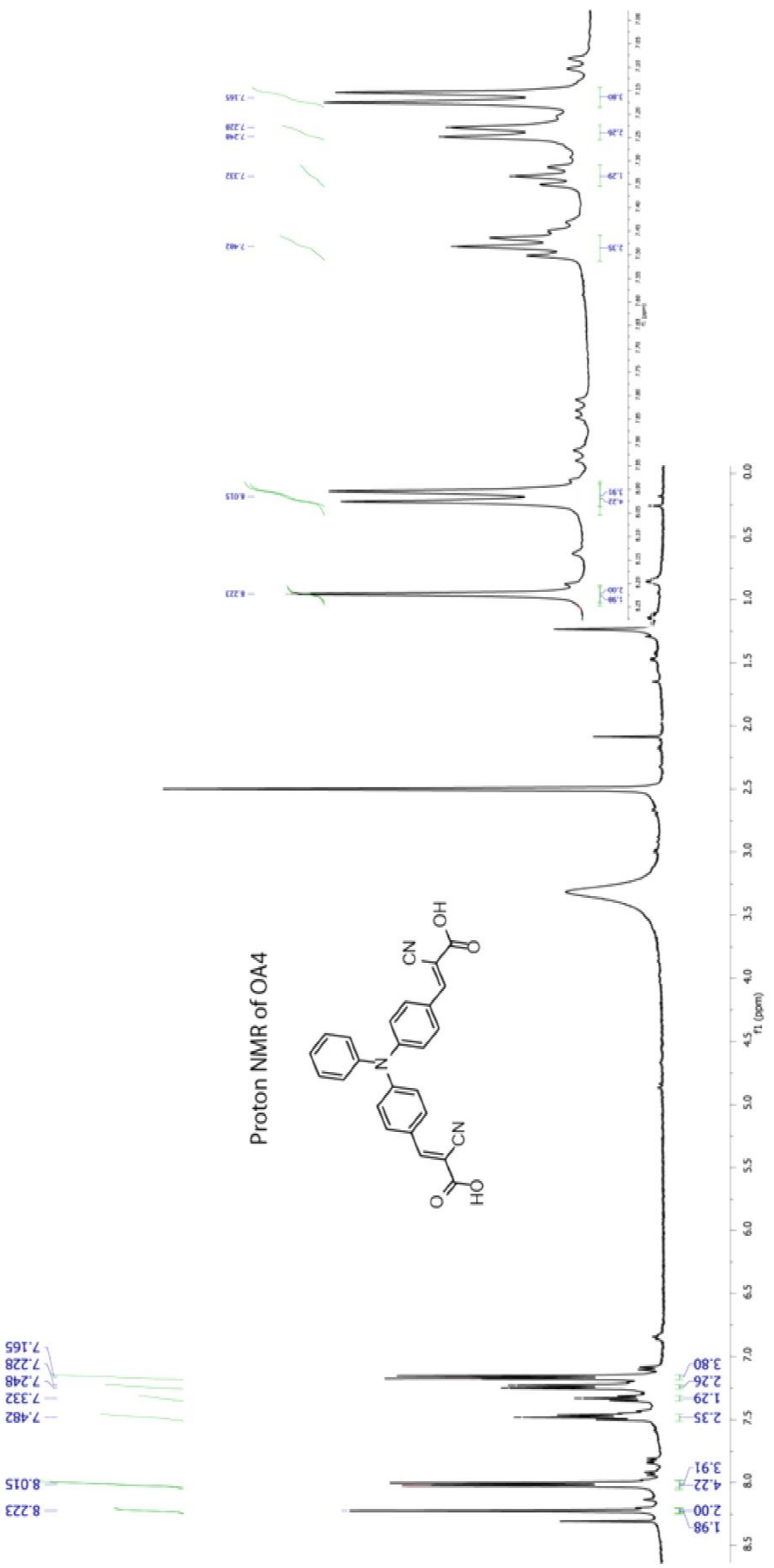




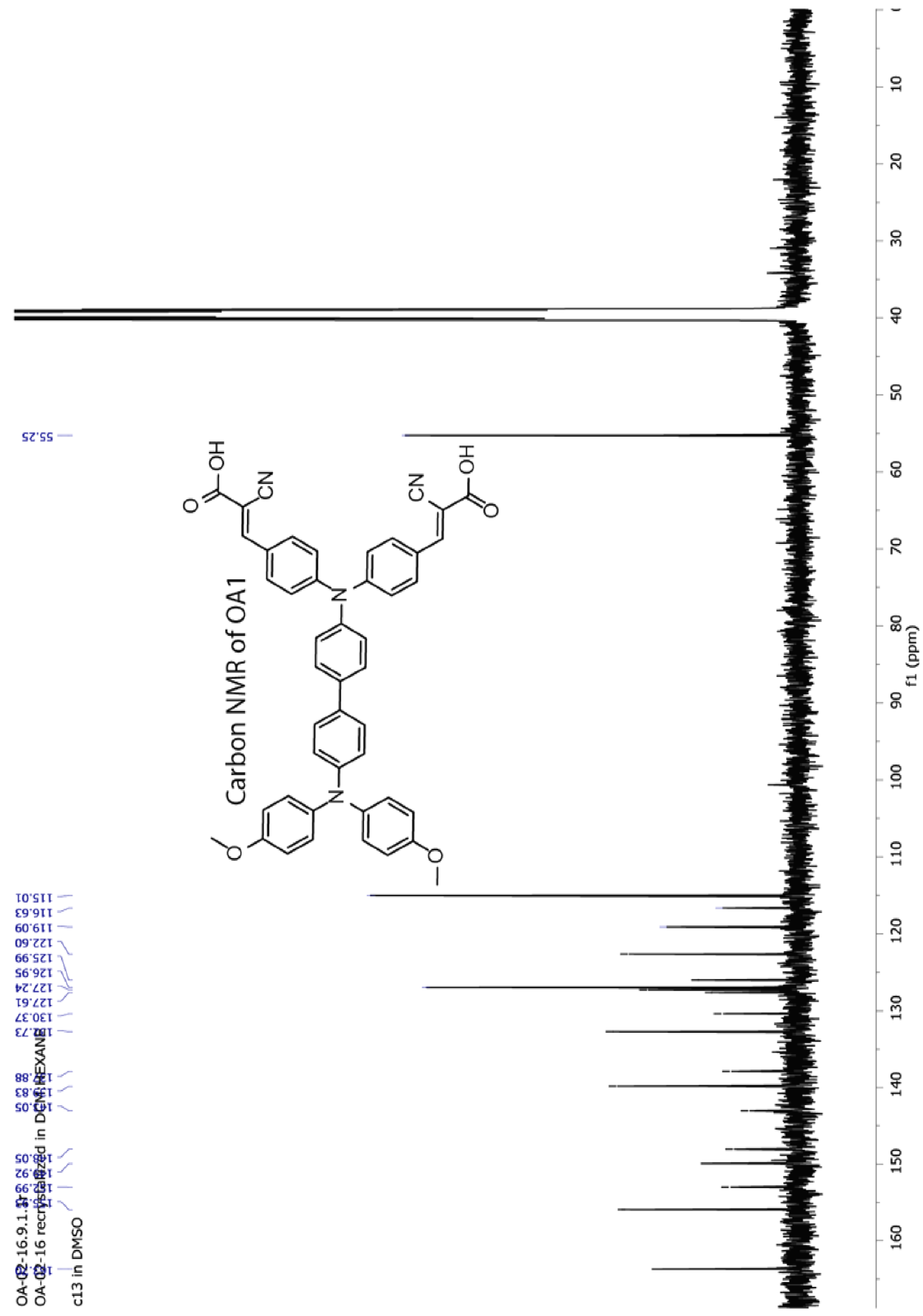




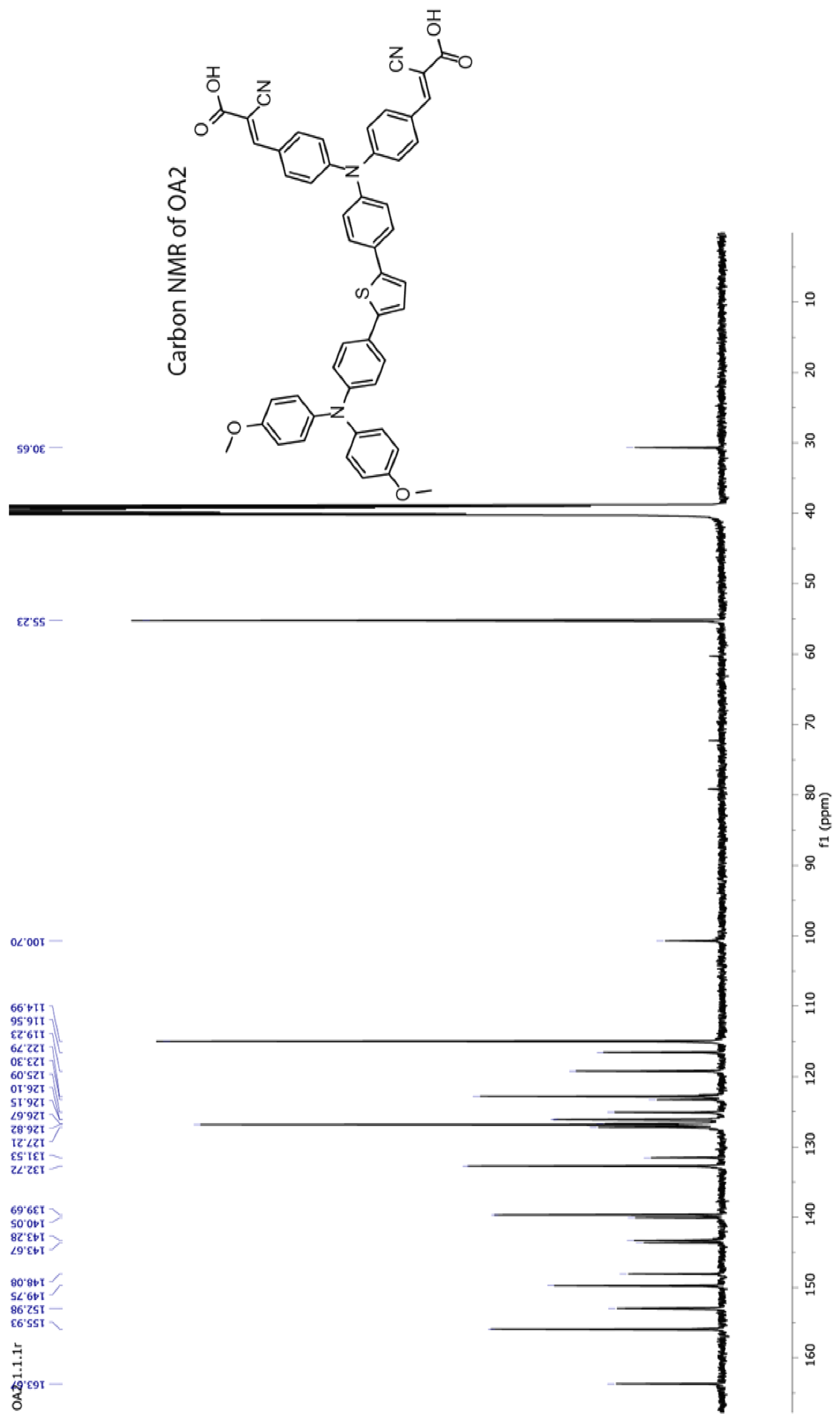




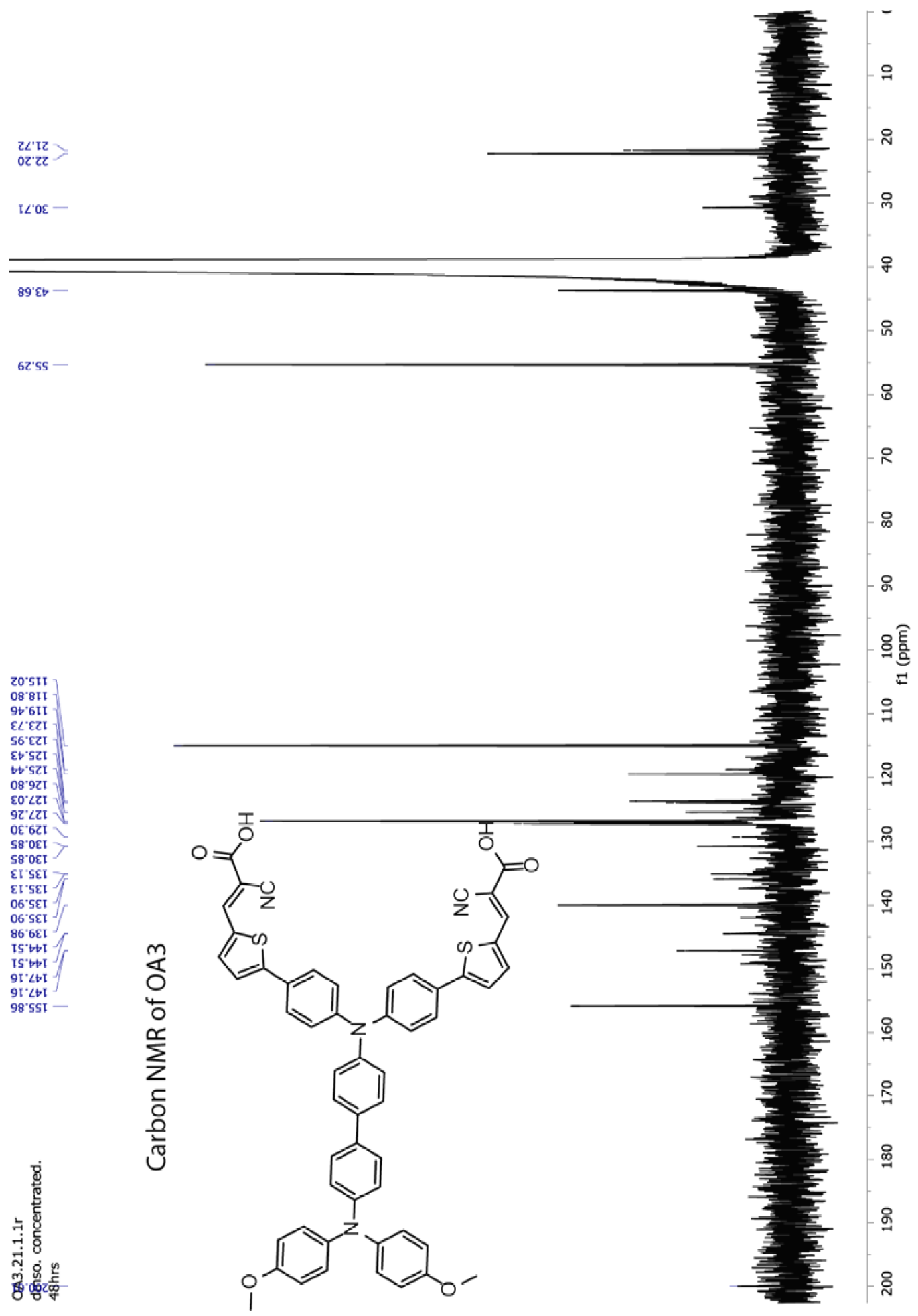




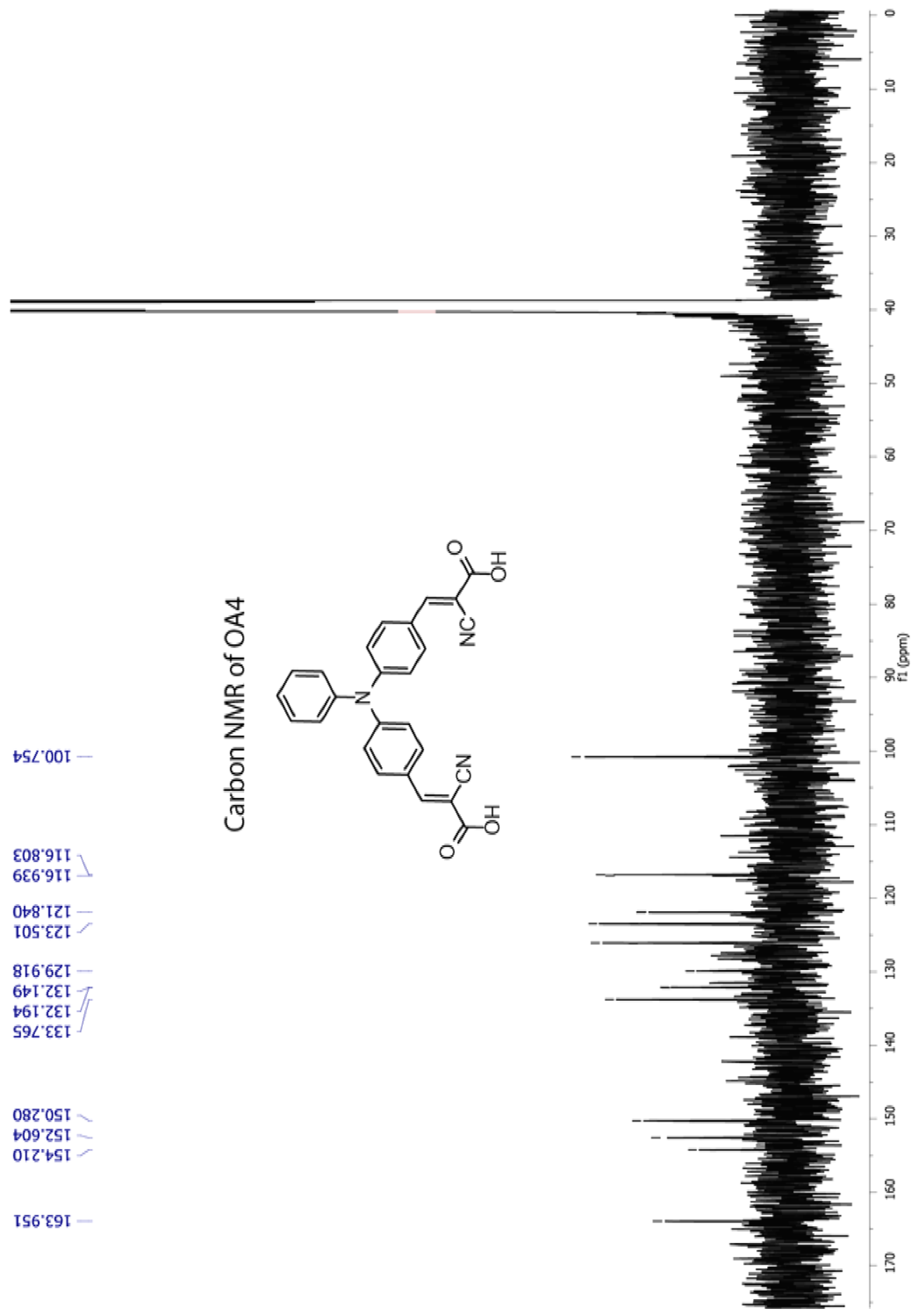




\section{References}

1. M. J. Frisch, G. W. Trucks, H. B. Schlegel, G. E. Scuseria, M. A. Robb, J. R. Cheeseman, J. A. Montgomery, T. Vreven, K. N. Kudin, J. C. Burant, J. M. Millam, S. S. lyengar, J. Tomasi, V. Barone, B. Mennucci, M. Cossi, G. Scalmani, N. Rega, G. A. Petersson, H. Nakatsuji, M. Hada, M. Ehara, K. Toyota, R. Fukuda, J. Hasegawa, M. Ishida, T. Nakajima, Y. Honda, O. Kitao, H. Nakai, M. Klene, X. Li, J. E. Knox, H. P. Hratchian, J. B. Cross, V. Bakken, C. Adamo, J. Jaramillo, R. Gomperts, R. E. Stratmann, O. Yazyev, A. J. Austin, R. Cammi, C. Pomelli, J. W. Ochterski, P. Y. Ayala, K. Morokuma, G. A. Voth, P. Salvador, J. J. Dannenberg, V. G. Zakrzewski, S. Dapprich, A. D. Daniels, M. C. Strain, O. Farkas, D. K. Malick, A. D. Rabuck, K. Raghavachari, J. B. Foresman, J. V. Ortiz, Q. Cui, A. G. Baboul, S. Clifford, J. Cioslowski, B. B. Stefanov, G. Liu, A. Liashenko, P. Piskorz, I. Komaromi, R. L. Martin, D. J. Fox, T. Keith, A. Laham, C. Y. Peng, A. Nanayakkara, M. Challacombe, P. M. W. Gill, B. Johnson, W. Chen, M. W. Wong, C. Gonzalez and J. A. Pople, Gaussian 03; Gaussian Inc., Wallingford, CT, 2009.

2. S.T., Meek; E.E., Nesterov and T.M. Swager. Org. Lett, 2008, 10, 2991.

3. S., Steinberger; A., Mishra; E., Reinold; E., Mena-Osteritz; H., Muller; C., Reinold; M., Pfeiffer and P., Bauerle. J. Mater. Chem, 2012, 22, 2701.

4. G., Fu; M., Wang; Y., Wang; N., Xia; X., Zhang; M., Yang; P., Zheng; W., Wang and C., Burger. New. J. Chem. 2005, 29, 792.

5. K., Ghosh; G., Masanta and A.P., Chattopadhyay. Eur. J. Org. Chem. 2009, 26, 4515

6. C., Teng; X., Yang; C.,Yang; S., Li; M., Cheng; A., Hagfeldt and L., Sun. J. Phys. Chem. C. 2010, 114, 9101.

7. J., Lee; J., Kim; G., Kim and C., Yang. Tetrahedron. 2010, 66, 9440. 